\title{
Control constitucional en el mundo contemporáneo - Retrospectiva y prospectiva*
}

\author{
Judicial review in the contemporary \\ world - Retrospective and \\ prospective*
}

Controle constitucional no mundo contemporâneo: retrospectiva e prospectiva*

Doreen Lustig**

J. H. H. Weiler***

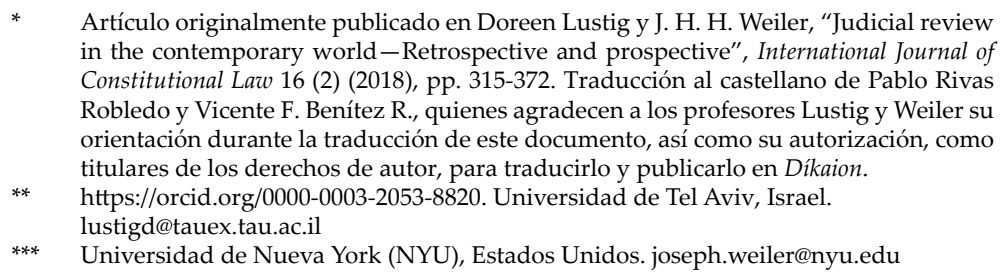

DOI: $10.5294 /$ dika.2021.30.2.1 Doreen Lustig, J. H. H. Weiler, "Control constitucional en el mundo contemporáneo - Retrospectiva y prospectiva", en Díkaion 30, 2 (2021), 244-334. DOI: https://doi.org/10.5294/dika.2021.30.2.1 


\section{Resumen}

Nuestro propósito en este artículo es retomar, actualizar y revisar teóricamente Judicial Review in the Contemporary World, de Mauro Cappelletti, una obra que fue pionera en su tratamiento del control constitucional. El principal recurso cartográfico, en homenaje a Cappelletti, es la metáfora de la ola. Trazamos un mapa de tres olas globales de control constitucional dentro de un mismo orden constitucional, las cuales son secuenciales y están superpuestas geográficamente a nivel mundial. La primera ola es la serie de "revoluciones constitucionales" al interior de los ordenamientos jurídicos nacionales. La segunda ola es la aparición del derecho internacional como fuente de derecho superior que los tribunales utilizan en el ejercicio de su poder de control constitucional. La tercera ola es una respuesta y reacción a la primera y segunda olas: por un lado, el intento de los tribunales nacionales de suplir las lagunas democráticas e identitarias del Estado de derecho en el marco de la gobernanza transnacional (tener una voz). Por el otro, es el conjunto de casos en los que los tribunales (y los Estados) tratan de escapar de la primera o la segunda ola (el escape). La interacción entre las olas y sus características dialécticas constituyen el marco explicativo que ofrecemos en este artículo. Al destacar las relaciones dialécticas dentro de las olas y entre ellas, esperamos desafiar la narrativa dominante sobre los procesos de constitucionalización como algo progresivo y evolutivo.

\section{Palabras clave}

Control de constitucionalidad; derecho internacional; identidad; democracia. 


\section{Abstract}

Our purpose in this Foreword article is to revisit, update, and theoretically revise Mauro Cappelletti's path-breaking work Judicial Review in the Contemporary World. Our main cartographical device, in homage to Cappelletti, is the wave metaphor. We map three sequential and overlapping worldwide, global waves of judicial review within a constitutional order. The first wave is the series of "constitutional revolutions" within national legal orders. The second wave is the emergence of international law as the source of the higher law which courts use in their exercise of their power of judicial review. The third wave is a response and reaction to the first and second waves: one dimension of the third wave is the attempt of domestic courts to make up for the rule of law, democratic and identitarian lacunae in transnational governance (voice). Another dimension - exit-is the set of instances in which courts (and states) seek to exit the first and/or the second wave. The interplay between the waves and their dialectical features constitute the explanatory framework we offer in this article. By highlighting the dialectical relations within and between waves we hope to challenge a dominant narrative on constitutionalization processes as progressive and evolutionary.

\section{Keywords}

Constitutional review; international right; identity; democracy. 


\section{Resumo}

O objetivo deste artigo é retomar, atualizar e revisar teoricamente a Judicial Review in the Contemporary World, de Mauro Cappelletti, uma obra que foi pioneira em seu tratamento do controle constitucional. Nosso principal recurso cartográfico, em homenagem a Cappelletti, é a metáfora da onda. Traçamos um mapa de três ondas globais de controle constitucional dentro de uma mesma ordem constitucional, as quais são sequenciais e estão sobrepostas geograficamente no mundo. A primeira onda é a série de "revoluções constitucionais" no interior dos ordenamentos jurídicos nacionais. A segunda onda é o surgimento do direito internacional como fonte de direito superior que os tribunais utilizam no exercício de seu poder de controle constitucional. A terceira onda é uma resposta e reação à primeira e à segunda ondas: por um lado, a tentativa dos tribunais nacionais de preencher as lacunas democráticas e identitárias do Estado de direito no âmbito da governança transnacional (ter uma voz). Por outro, é o conjunto de casos nos quais os tribunais (e os Estados) tentam escapar da primeira ou da segunda $(a f u g a)$. A interação entre as ondas e suas características dialéticas constituem o referencial explicativo que oferecemos neste artigo. Ao destacar as relações dialéticas dentro das ondas e entre elas, esperamos desafiar a narrativa dominante sobre os processos de constitucionalização como algo progressivo e evolutivo.

\section{Palavras-chave}

Controle de constitucionalidade; direito internacional; identidade; democracia. 
Sumario: 1. Génesis - En el principio... 2. Retrospectiva - Control constitucional y derecho público. 2.1. La primera ola - La difusión del control constitucional. 2.2. La segunda ola - Las dimensiones internacional y transnacional. 2.3. La primera y segunda olas: fundamento(s) y explicación(es). 2.3.1. Fundamento(s). 2.3.2. Explicación(es): agregando los ejes horizontal y vertical a las explicaciones existentes. 3. Prospectiva. 3.1. La crítica contramayoritaria. 3.2. La cultura del individualismo - El déficit republicano. 3.3. El aplanamiento de la identidad. 3.4. Preocupaciones distributivas marginalizadas. 3.5. El déficit democrático: gobernanza sin gobierno. 4. La tercera ola: reacción, movimiento dialéctico o arrebatamiento radical. 4.1. La regla de manifestación de la tercera ola. 4.2. La democracia y la manifestación del desafío mayoritario de la tercera ola. 4.3. La identidad como un escape de la tercera ola. 4.4. Localización: la identidad como la voz de la tercera ola. Conclusión - La tragedia del control de constitucionalidad en el mundo contemporáneo. Bibliografía.

\section{Génesis - En el principio...}

A principios de la década de los setenta, en su Judicial Review in the Contemporary World, Mauro Cappelletti trazó un mapa de la difusión por todo el mundo de un constitucionalismo marcado por el control constitucional, mostrando el inicio de su obstinada difusión planetaria de la mano y como parte de la expansión de la democracia en la época posterior a la Segunda Guerra Mundial. ${ }^{1}$ A pesar de su brevedad (en la versión en lengua inglesa), era una obra de gran erudición y ejemplar dominio comparativo. Tuvo un carácter "profético" en el doble sentido de esta palabra: empíricamente, sostuvo que el control, en ese momento una excepción en el mapa del derecho público mundial, estaba conquistando el mundo democrático, de hecho, convirtiéndose en parte de la ontología democrática: lo que significa ser una democracia. Normativamente, esta expansión, a los ojos de Cappelletti, involucraba un bien público no calificado aún. Era una visión que combinaba una fe en dos cosas:

- La fe en una "ley superior" que vincula incluso a los órganos democráticos, cuyo principal contenido son normas que protegen los derechos y las libertades individuales contra las tiranías, incluso las de las mayorías democráticas.

- La fe en los tribunales, ya sea constitucionales o promiscuos, supremos u ordinarios, como la garantía más eficiente para la eficacia y el cumplimiento de ese derecho superior. El control constitucional se convirtió en un signo distintivo de la propia noción de Estado de derecho.

Con independencia de lo que se pueda pensar de la visión lineal de Cappelletti, especialmente problemática en su dimensión normativa, empíricamente, en su mayor parte, una u otra versión de este modelo simple y convincente no solo ha continuado su difusión en todo el mundo, sino que se ha conver-

1 M. Cappelletti, Judicial Review in the Contemporary World, Indianapolis, Bobbs-Merrill, 1971. 
tido no solo en ortodoxia, sino en doxa. ${ }^{2}$ Es difícil encontrar una constitución redactada en el último medio siglo que no haya adoptado alguna variante de este modelo.

La filosofía subyacente está bien resumida en la decisión del Tribunal de Justicia de la Unión Europea (TJUE) en Les Verts, que hace eco de las palabras de Walter Hallstein: “La Comunidad Económica Europea es una Comunidad basada en el Estado de derecho, en la medida en que ninguno de los Estados miembros, ni sus instituciones, pueden evitar que se revisen o se ejerza control sobre las medidas adoptadas por estos para determinar si son conformes con el Tratado". ${ }^{3}$

Una democracia sin alguna forma de control constitucional se considera deficiente. Este ha sido el caso en Europa, casi sin excepción. Y aunque la propagación del control constitucional del derecho administrativo es anterior y no sigue la misma historicidad del control judicial de la legislación, el nexo e intercambio que existe entre estos se ha hecho evidente. El TJCE, de forma escueta y contundente, definió que un aspecto central del propio Estado de derecho exige que todo acto jurídico que afecte la situación de cualquier agente jurídico debe ser, potencialmente, revisado por un tribunal. Y mientras que el control de constitucionalidad de la administración antes se obsesionaba con cuestiones intra y ultra vires, y con una forma débil de racionalidad como criterios de control sustantivo, hoy ambas versiones del control (de la legislación y de la administración) han puesto la proporcionalidad como herramienta y característica central del control constitucional.

Este desarrollo ha sido objeto de una rica literatura de naturaleza de científicosocial que explica las causas del surgimiento del control judicial y se ha convertido en un elemento básico de la teoría normativa del derecho público de todo tipo. Incluso los debates modernos, como el del pluralismo constitucional, ${ }^{4}$ están impulsados, y se aprovechan, tanto de la existencia de órdenes constitucionales superpuestos y en conflicto, así como del hecho de que estas constituciones en conflicto están "protegidas" por los tribunales que determinan el derecho aplicable.

La gran innovación y el logro de Cappelletti fue alejarse de la visión particularista y parroquial del constitucionalismo y sus descontentos dentro de un sistema determinado (una moda que nos acompaña al menos desde los Fede-

2 Según Tom Ginsburg y Mila Versteeg, el 38\% de los países tenían control constitucional en 1951 mientras que el 86\% lo tenía en 2011. T. Ginsburg y M. Versteeg, "Why do countries adopt constitutional review?", en The Journal of Law, Economics, and Organization 30 (3) (2014), p. 587. Véase, por ejemplo, W. Sadurski, Rights Before Courts: A Study of Constitutional Courts in Postcommunist States of Central and Eastern Europe, 2. Ed., Dordrecht, Springer, 2014.

3 European Court of Justice. Parti écologiste “Les Verts" v. European Parliament. Judgment of the Court of 23 April 1986. Case 294/83; W. Hallstein, Die europäische Gemeinschaft, 5 ed., Viene, Econ, 1979, p. 51.

4 K. Jaklic, Constitutional Pluralism in the EU, Oxford, Oxford University Press, 2014. 
ralist Papers y Marbury v. Madison) y retroceder, tomar distancia y presentar una imagen global. Fue un ejercicio valioso en sí mismo, que ayudó no solo a relativizar, sino también a quitarle relevancia a los feroces debates locales cuando tal o cual país, a través de una enmienda constitucional o una evolución judicial, adoptaba una forma de control constitucional. Si todo el mundo lo hace, ¿por qué debería avergonzarme si yo lo hago?

Por último, pero no por ello menos importante, introdujo una pizca de realismo en la evaluación normativa del modelo básico de control de constitucionalidad. A pesar de las recurrentes erupciones contra el modelo de control que surgen en un lado o en otro, impulsadas por las condiciones locales, se ha impuesto y consolidado la opinión de que no todo el mundo puede estar mal y que, al fin y al cabo, la democracia se ve reforzada, no disminuida, por el modelo básico de control constitucional.

La fe casi ingenua y religiosa de Cappelletti en el control judicial, no solo como "el camino hacia el futuro", sino como la "buena nueva" evangélica, ha sido en gran parte reivindicada al menos en el sentido empírico: ¿cómo más explicar la difusión del control constitucional más allá de razones locales para cada caso? Sin embargo, incluso si nos centramos solo en Europa, esta imagen lineal es mucho más compleja. Por un lado, aparte de los diferentes modelos de control constitucional en el derecho público adoptados en diferentes Estados, el advenimiento del control constitucional y el hecho de que sea atractivo para los tribunales se ha desarrollado -de hecho, explotado- más allá del nivel Estadonación, ya sea federal o unitario. El mundo ha visto un verdadero estallido en la evolución de los regímenes legales y la producción de leyes entre los Estados y, más allá de estos, en un sinnúmero de regímenes internacionales, regionales y globales, bilaterales y multilaterales, con un crecimiento concomitante en los órganos judiciales responsables de su aplicación. El derecho internacional en sí se ha expandido, tanto de manera uniforme como fragmentada, pero la participación del poder judicial, nacional y transnacional, nunca ha sido tan prominente como lo es hoy en día.

El ethos que prevalece en el orden jurídico internacional ha sido concebido durante mucho tiempo como aquel que procura un mínimo de orden y justicia entre los Estados soberanos que persiguen agresivamente sus intereses nacionales. La difusión del control constitucional agregó nuevas capas a este ethos, entre ellas el reconocimiento de que el futuro bienestar de la humanidad sería aceptar y construir un espíritu comunitario en el que el interés colectivo de la comunidad internacional esté por sobre el nivel del Estado y en el que el individuo y las regiones por debajo del Estado deberían ser el centro de nuestra atención y, en ocasiones, incluso deberían priorizarse.

En esta historia, el derecho internacional ya no estaba dominado por tratados estáticos negociados por los Estados -a menudo ratificados por sus 
órganos legislativos- y que luego constituían tranquilamente las reglas de juego para sus principales sujetos, los Estados. El derecho internacional se había convertido en una matriz desconcertante de cientos de organizaciones regionales e internacionales, funcionales y con identidad propia, con una producción legislativa, "constitucional" y regulatoria, masiva, mal coordinada y a menudo contradictoria. Dicho de otra manera, los niveles internacional y transnacional dejaron de ser un mero escenario de coordinación y negociación de intereses en conflicto para convertirse en una arena de gobernanza, donde una miríada de funciones hasta entonces ejercidas por el Estado, especialmente en la esfera administrativa, se transfirieron a la esfera regional, transnacional y global.

Este nuevo tipo de interacción requirió nuevos foros para los órganos de resolución de disputas entre los Estados (como cortes y tribunales), siguiendo el modo del antiguo orden jurídico internacional. Adicionalmente, se dio impulso a una nueva justificación para tales cortes y tribunales: garantizar el cumplimiento (y no la mera solución de controversias), entre otras cosas, para evitar el aprovechamiento gratuito de los sistemas multilaterales y para ampliar la justificación antes mencionada del Tribunal Europeo de Justicia, garantizando el Estado de derecho en cualquier nivel de gobernanza.

En consecuencia, surgió un crecimiento similar de cortes y tribunales de diferente jurisdicción, competencia y poderes, medido en cientos y miles (si se cuenta el advenimiento de los tratados bilaterales de inversión), pero todos arraigados en la convicción de que los tribunales y el control constitucional, de una u otra índole, eran tan indispensables para el rule of law del derecho internacional como lo eran para el rule of law estatal. De hecho, las fronteras entre los dos se vuelven cada vez más borrosas como resultado de estos dos procesos.

El mundo que describió Cappelletti era en cierto modo newtoniano: grandes objetos (constituciones, tribunales constitucionales o supremos) que se movían a baja velocidad en trayectorias previstas, con algún cometa o neutrino ocasional que perturbaba el magisterio comparativista. El artesano académico del centro era un comparatista constitucional. Ahora nuestro mundo es einsteiniano. Objetos grandes y pequeños se mueven a mayor velocidad, con poco orden aparente, atraídos y repelidos simultáneamente, chocándose, disolviéndose, fusionándose y dividiéndose con el artesano académico, que es un nacional/ transnacionalista de derecho público en sentido amplio.

Nuestro propósito aquí es retomar, actualizar y revisar teóricamente la construcción de Cappelletti. El primer propósito de nuestro enfoque es cartográfico, ya que se trata de trazar un mapa de un derecho público que ahora es 251 mucho más complejo. 
Nuestro dispositivo cartográfico, en homenaje a la otra gran obra de Cappelletti, Access to Justice, ${ }^{5}$ será la metáfora de las olas, lo que permite una representación tanto temporal como espacial. Trazaremos un mapa de tres olas, a veces secuenciales y a veces superpuestas, que en nuestra opinión describen de manera adecuada tanto el desarrollo europeo como el del mundo contemporáneo. ${ }^{6}$

La primera ola es la difusión horizontal del control constitucional (o la voluntad más sólida de los tribunales de utilizar los mecanismos ya existentes) entre los ordenamientos jurídicos a nivel estatal. La característica principal de la primera ola es el surgimiento de mecanismos judiciales de control de constitucionalidad de las acciones estatales dentro de los Estados, incluyendo legislación aprobada democráticamente. La segunda ola es el surgimiento de órdenes transnacionales de nivel superior; en Europa, el hecho más notable, pero seguramente no único, es la ratificación de la Convención Europea de Derechos Humanos (CEDH) y la creación de la Unión Europea (UE). El sometimiento de los Estados a los tribunales internacionales en el proceso de solución de controversias no es nada nuevo y difícilmente forma parte del universo del control constitucional. Lo que es novedoso en la segunda ola es el sometimiento de los Estados al control judicial en contextos internacionales, más allá de la simple solución de controversias, así como el asunto objeto de control (actos internos del Estado dentro de su jurisdicción), algo que típicamente estaba fuera del alcance de la adjudicación internacional. Pero algo aún más importante en la fisonomía de la segunda ola ha sido el uso creciente de las normas internacionales por parte de los tribunales nacionales como una norma superior dentro de los contextos constitucionales. Por lo tanto, en nuestra opinión, no puede haber duda de su centralidad en el paisaje marino del control constitucional.

La tercera ola tiene dos facetas principales. En parte, muestra el surgimiento de los tribunales nacionales como una instancia de control y revisión judicial de la gobernanza y la adjudicación transnacionales e internacionales; en parte, es también una expresión de una nueva dimensión identitaria en el discurso constitucional. Ambas facetas plantean cuestiones normativas complejas para el orden jurídico.

Nuestra tesis no es solo que esta cartografía proporciona un principio organizador y una descripción más significativa para el fenómeno explosivo mencionado anteriormente, sino que, a través de una comprensión de la interacción

$5 \quad$ M. Cappelletti y B. Garth, "Access to justice and the welfare state: An introduction", en M. Cappelletti (ed.), Access to Justice and the Welfare State, Fiesole, European University Institute, 1981; S. P. Huntington, The Third Wave: Democratization in the Late 20th Century, Norman, University of Oklahoma Press, 1993.

$2526 \begin{aligned} & \text { Con frecuencia utilizamos "constitucionalización" como un sustituto de la adopción del control constitucio- } \\ & \text { nal dentro de un sistema constitucional. En este sentido, llamamos la atención sobre el nexo que se mencionó }\end{aligned}$ anteriormente entre lo constitucional y lo administrativo, cuyos límites, sobre todo en la esfera transnacional, se están rompiendo. 
de las olas, se proporciona un aparato explicativo más rico para el control constitucional en el mundo contemporáneo.

Lo que llamamos la primera y segunda oleadas han sido el elemento básico de la teoría del derecho constitucional durante décadas y nuestra contribución será principalmente de síntesis. Es una narrativa con la que la mayoría de los lectores estarán familiarizados, aunque esperamos que nuestra sistematización tenga algún valor. Esperamos que la identificación del surgimiento de la tercera ola (o quizás, en este momento, una simple marea) y el análisis de su génesis, fronteras y significado sea una contribución significativa a la historia, historiografía y teoría del control judicial existentes en el mundo contemporáneo. En pocas palabras, argumentamos que la tercera ola es una reacción a las otras dos olas. Dicho de otra manera, proponemos y mostramos cómo los desafíos planteados por el constitucionalismo interno y el constitucionalismo transnacional, tomados en conjunto, están provocando una corrección e incluso una reacción intensa que se ve reflejada en la tercera ola. Además, argumentamos que la tercera ola o esta reacción intensa podría concebirse como el resultado de una tensión entre el constitucionalismo doméstico (primera ola) y transnacional (segunda ola), que clásicamente se han concebido como complementarios.

A continuación, se presenta una breve "hoja de ruta" que debería ayudar al lector a navegar a través de esta narrativa algo compleja.

En la sección 2 de este artículo sintetizamos, breve y empíricamente, la trayectoria de las dos primeras olas. Luego de ello, ofrecemos un resumen de las causas y los fundamentos que explican estos desarrollos históricos con especial énfasis en la interacción entre las olas.

La sección 3 comienza con una descripción y análisis de las posibles objeciones y reacciones (legales, políticas y sociales) a las dos primeras olas. Esto es importante para nuestra tesis, pues sostenemos que la tercera ola es dialécticamente reactiva a la primera y segunda olas.

En la sección 4, exploramos las fronteras de la tercera ola. Una dimensión de la tercera ola, volviendo a la tipología siempre fresca de Hirschman, expresar una voz, es el intento de los tribunales nacionales de compensar los déficits del Estado de derecho, de las lagunas democráticas e identitarias en la gobernanza y de la adjudicación transnacionales, así como para sostener su supremacía constitucional y controlar el poder de los regímenes de gobernanza transnacional. Otra dimensión, el escape, es el conjunto de instancias en las que los tribunales (y los Estados) buscan salir de la primera o la segunda ola. No analizaremos el grave debilitamiento de los tribunales constitucionales nacionales y el control de constitucionalidad en Hungría, Polonia, Venezuela y Turquía, o el escape a los regímenes de gobernanza global en casos como Sudáfrica y la 
Corte Penal Internacional (CPI) o el Reino Unido y el Brexit. Estas instancias radicales de escape deben informar e influir en la toma de decisiones judiciales. Sin embargo, deseamos concentrarnos en la opción de escape tal como es ejercida por los tribunales constitucionales y supremos de carácter nacional (y no contra dichos tribunales). El escape al que nos referimos se relaciona con casos en los que los tribunales cuestionan, desafían o modifican directamente la legislación internacional transnacional. Deseamos explorar los contextos en los que lo hacen y rastrear su posible justificación.

Las explicaciones que ofrecemos aquí no son las únicas, ni siquiera las más importantes, de las reacciones intensas o backlash. Esperamos hacer una contribución más modesta al complementar la habitual historia del auge actual del populismo, el nacionalismo y el autoritarismo, al explicar el papel que desempeñan las instituciones jurídicas en estos procesos. Admitimos que estas explicaciones difícilmente equivalen a un esclarecimiento robusto propio de las ciencias sociales, pero esperamos que, junto con el marco más amplio que ofrecemos, puedan proporcionar una forma útil de comprender las características importantes de este proceso de múltiples niveles.

\section{Retrospectiva - Control constitucional y derecho público}

Nuestro trabajo aquí se ocupa, principalmente, del control constitucional. No obstante, los límites de lo "constitucional" son a menudo difusos. Como se señaló, existe una relación causal supuestamente muy limitada entre el auge del control de constitucionalidad administrativo y el control constitucional propiamente dicho sobre la legislación. Sin embargo, para los jueces que aplican el control constitucional sobre los actos del poder legislativo existen importantes analogías entre su práctica y el previamente arraigado control de constitucionalidad administrativo. En ambos casos, los jueces esperan limitar y controlar el aparato estatal en nombre del Estado de derecho y cada vez más en beneficio de las minorías. Del mismo modo, el control constitucional nacional dentro de varios marcos internacionales o transnacionales (control constitucional de segunda ola) no siempre es un ejercicio puro de control de constitucionalidad "constitucional": no hay una fuente de derecho clara que podamos identificar como una "constitución internacional". Y, en la práctica, tampoco se trata de un intento de anular "legislación" internacional o nacional por violar una norma constitucional. Sin embargo, el control constitucional de segunda ola no se basa simplemente en los fundamentos del derecho administrativo como el carácter ultra vires, la razonabilidad o el "margen de apreciación". Más bien, se basa en la presunción de jerarquía entre las normas internacionales como normativamente superiores y, por lo tanto, como una base a partir de la cual se ejerce control de constitucionalidad sobre las prácticas, decisiones y actuaciones legislativas de los Estados. Por lo tanto, el control constitucional de segunda ola 
presenta una combinación de control de constitucionalidad "constitucional" (ya que extrae su fundamento normativo de la noción de normas internacionales jerárquicamente superiores) y control de constitucionalidad administrativo (ya que no se aplica estrictamente para evaluar la constitucionalidad de actuaciones legislativas, sino para controlar y examinar también los actos de los órganos administrativos). ${ }^{7}$ Con este tipo de advertencias, nos sentimos cómodos al usar la etiqueta "constitucional" o "constitucionalidad".

\section{La primera ola - La difusión del control constitucional}

La primera ola (más que ola, un verdadero tsunami), se remonta conceptualmente con frecuencia a Marbury $v$. Madison (1803), a pesar de que se origina en precedentes mucho más antiguos. ${ }^{8}$ Durante el siglo XIX, otras jurisdicciones respaldaron el control de constitucionalidad fuera de los Estados Unidos, especialmente en América Latina, ${ }^{9}$ pero también en Europa ${ }^{10}$ con un éxito limitado. Sin embargo, estos respaldos anteriores tenían poca o ninguna importancia práctica. A pesar de la relevancia de Marbury v. Madison, la institución del control constitucional tardaría aproximadamente un siglo en expandirse más allá de las fronteras principalmente estadounidenses y convertirse en un fenómeno global.

La conocida historia del control constitucional en el siglo XX se describe típicamente como una historia evolutiva: una serie de "revoluciones constitucionales" dentro de los ordenamientos jurídicos, cuyos dos puntos de inflexión históricos son el final de la Segunda Guerra Mundial y el final de la Guerra Fría. ${ }^{11}$ Esta narrativa familiar a menudo tiende a ignorar otros periodos del siglo XX, con significativa actividad constitucional, como el periodo de entreguerras, durante el cual el control constitucional floreció, al menos como un

7 Para un panorama histórico del derecho administrativo véase P. Cane (ed.), "Administrative interpretation", en Controlling Administrative Power: An Historical Comparison, Cambridge, Cambridge University Press, 2016, cap. 6.

8 Mary Sarah Bilder es una de las que ha estudiado la pre-historia del control constitucional. Véase M. S. Bilder, "The corporate origins of judicial review", en Yale Law Journal 116 (2006), p. 502. Otros han defendido puntos similares respecto a antecedentes incluso más remotos. Véanse C. Hobson, "The origins of judicial review: A historian's explanation", en Washington and Lee Law Review 56 (3) (1999), p. 811; S. Prakash y J. Yoo, “The origins of judicial review", en University of Chicago Law Review 70 (3) (2003), p. 887; J. N. Rakove, "The origins of judicial review: A plea for new contexts", en Stanford Law Review p. 1031; W. M. Treanor, "Judicial review before Marbury", en Stanford Law Review 58 (2) (2010), p. 455. Para una discusión sobre estas tesis revisionistas, véase G. Wood, "the origins of judicial review revisited, or how the Marshall Court made more out of less", en Washington and Lee Law Review 56 (3) (1999), p. 787.

9 D. Bushnell y N. MacAulay, The Emergence of Latin America in the Nineteenth Century, 2 ed., New York, Oxford University Press, 1994; P. Navia y J. Ríos-figueroa, "The constitutional adjudication mosaic of Latin America", en Comparative Political Studies, 38(2), 2005, en https://doi.org/10.1177/0010414004271082, p. 193.

10 Suecia, Dinamarca y Noruega son parte de una tradición en la cual se reconoce el control constitucional en teoría, pero en la práctica tiene un alcance muy limitado. J. Husa, "Guarding the constitutionality of laws in the nordic countries: A comparative perspective", en The American Journal of Comparative Law 48 (3) (2000), p. 345.

11 S. Gardbaum, "Separation of powers and the growth of judicial review in established democracies (or Why has the model of legislative supremacy mostly been withdrawn from sale?)", en American journal of comparative law, 3, 2014, pp. 613, 613-614, 619-627. 
ideal, en Europa ${ }^{12}$ junto con importantes innovaciones en esa dirección en otras jurisdicciones. ${ }^{13}$ Algunos Estados latinoamericanos, tales como México, Brasil y Cuba, experimentaron cambios constitucionales importantes durante este periodo, aunque con implicaciones prácticas pobres. ${ }^{14}$ Irak, Turquía, China y Filipinas promulgaron constituciones que incluían disposiciones sobre control constitucional durante el mismo periodo. ${ }^{15} \mathrm{El}$ debate francés de principios del siglo XX, especialmente hacia 1925, sobre la aprobación de un modelo de control constitucional al estilo estadounidense, es un ejemplo de ello junto con la inclusión del control constitucional en el artículo 102 de la Constitución de Weimar. ${ }^{16} \mathrm{~A}$ pesar de esto, estos dos ejemplos no dieron lugar a una tradición de control constitucional. ${ }^{17}$

El control constitucional en el periodo anterior a la Primera Guerra Mundial se diseñó siguiendo el modelo estadounidense descentralizado o difuso (modelo de acuerdo con el cual cada tribunal tiene la autoridad para declarar inconstitucional una ley). Después de la Primera Guerra Mundial, el Tribunal Constitucional de Austria (1920-1933) se diseñó de acuerdo con el modelo kelseniano. ${ }^{18}$ Según el modelo kelseniano centralizado o concentrado, el control constitucional solo puede ser ejercido por un único tribunal constitucional, mediante un procedimiento especial diseñado para tal fin. ${ }^{19} \mathrm{El}$ modelo de Kelsen ganó preeminencia en el periodo de entreguerras, pues se introdujo, aunque sin éxito, en la entonces Checoslovaquia y en España. ${ }^{20}$

La narrativa clásica señala 1945 como el punto de inflexión. Antes de la Segunda Guerra Mundial, el modelo de supremacía parlamentaria era el modelo

12 L. Favoreu, "Constitutional Review in Europe", en L. Henkin y A. Rosenthal (eds.), Constitutionalism and Rights: The Influence of the United States Constitution Abroad, New York, Columbia University Press, 1989; M. Stolleis, "Judicial review, administrative review, and constitutional review in the Weimar Republic", en Ratio Juris, 16 (2) (2003), pp. 266, 277. Mauro Cappelletti discutió el fracaso del modelo francés y weimariano de control constitucional. Véase Cappelletti, Judicial Review in the Contemporary World, op. cit., pp. 53-66.

13 Para más detalles véase, por ejemplo, D. Deener, "Judicial review in modern constitutional systems", en The American Political Science Review 46 (4) (1952), pp. 1079, 1086-1090.

14 Constitución de Cuba, 1992; Constitución de la República Federativa de Brasil, 1988; Constitución Política de los Estados Mexicanos, 2005.

15 Para mayor información sobre este periodo, véase Deener, “Judicial review in modern constitutional systems", op. cit.

16 Favoreu, "Constitutional review in europe", op. cit. Para mayor información sobre el fracaso de ratificación del control constitucional durante el periodo entre guerras, véase Cappelletti, Judicial Review in the Contemporary World, op. cit., pp. 53-66.

17 Sobre el fracaso del control constitucional en la República de Weimar a la luz de la oposición pública e institucional, véase Stolleis, "Judicial review, administrative review, and constitutional review in the Weimar Republic", op. cit., p. 277.

18 En un artículo publicado en 1928, Kelsen desarrolló una teoría en la cual se defendía un modelo centralizado de control constitucional. H. Kelsen, "La garantie juridictionnelle de la Constitution", en Revue de Droit Publique et Science Politique en France et á l'Étranger 45 (1928), p. 197.

19 Para mayor discusión, véase J. Ferejohn y P. Pasquino, "Constitutional adjudication: Lessons from Europe",

256 en Texas Law Review 82 (2003), pp. 1671, 1681-1700; A. Stone Sweet, Governing with judges: constitutional politics
in Europe, Oxford, Oxford University Press, 2000, cap. 6.
20 S. Gardbaum, “The new commonwealth model of constitutionalism”, en The American Journal of Comparative

256 en Texas Law Review 82 (2003), pp. 1671, 1681-1700; A. Stone Sweet, Governing with judges: constitutional politics
in Europe, Oxford, Oxford University Press, 2000, cap. 6. Law, 49 (4) (2001), pp. 707, 713-714. 
constitucional dominante. ${ }^{21}$ Según la narrativa común, fue la experiencia de la guerra y los regímenes totalitarios lo que llevó a la gente a perder la fe en la legislatura y en la idea de un parlamento ilimitado. Esta pérdida de fe allanó el camino para el respaldo del control constitucional como un mecanismo de equilibrio y control del poder de los funcionarios electos. Esta transición incluyó cambios ideológicos profundos (hacia un mayor consenso sobre las normas constitucionales) que, a su vez, produjeron cambios estructurales (la jerarquía constitucional suprema solo sería posible a través del control constitucional). De hecho, la base ideológica para el ejercicio de control constitucional permaneció arraigada en la tradición estadounidense; la victoria de Estados Unidos en la guerra y su participación en la reconstrucción de Europa contribuyeron a inyectar sus valores e ideas en otros países. ${ }^{22}$

Sin embargo, el marco institucional que finalmente adoptaron los Estados difería de su contraparte estadounidense, prefiriendo el modelo kelseniano centralizado. En el marco de este proceso, los derechos humanos se convirtieron en una característica central en la introducción de nuevas constituciones. El control constitucional se introdujo en las antiguas Potencias del Eje, Alemania (1949), ${ }^{23}$ Italia (1948) ${ }^{24}$ y Japón (1947). ${ }^{25}$ El Tribunal Constitucional de 1929 fue reinstalado en Austria con una nueva Constitución en $1945 .{ }^{26} \mathrm{El} \mathrm{mo-}$ delo concentrado fue adoptado en Chipre (1960), Turquía (1961) y Yugoslavia (1963). ${ }^{27}$ Otra coyuntura importante en este proceso ocurrió en la década de los setenta. Países como España (1978), Portugal (1982) y Grecia (1975) se convirtieron en democracias y adoptaron un modelo de control constitucional. ${ }^{28}$ En Francia, el Conseil Constitutionnel no usó su autoridad para ejercer el control de constitucionalidad (desde 1958) hasta $1971 .{ }^{29}$ Algunos consideran que Bél-

21 Este modelo estaba incorporado en la doctrina británica de supremacía parlamentaria y en la doctrina francesa, como queda claro en la Declaración de los Derechos del Hombre y del Ciudadano de 1789 en su artículo $6^{\circ}$ : “La Ley es la expresión de la voluntad general. Todos los Ciudadanos tienen derecho a contribuir a su elaboración, personalmente o a través de sus Representantes. Debe ser la misma para todos, tanto para proteger como para sancionar. Además, puesto que todos los Ciudadanos son iguales ante la Ley, todos ellos pueden presentarse y ser elegidos para cualquier dignidad, cargo o empleo públicos, según sus capacidades y sin otra distinción que la de sus virtudes y aptitudes".

22 B. Ackerman, "The rise of world constitutionalism", en Virginia Law Review 83 (4) (1997), pp. 771, 772-773. Cfr. con D. P. Kommers, The Constitutional Jurisprudence of the Federal Republic of Germany, Durham, Duke University Press, 1997.

23 D. P. Kommers y R. A. Miller, The Constitutional Jurisprudence of the Federal Republic of Germany: Third edition, Revised and Expanded, Durham, Duke University Press, 2012.

24 Constitución de la República Italiana, 1948, art. 134; C. Thornhill, A Sociology of Constitutions: Constitutions and State Legitimacy in Historical-Sociological Perspective, Cambridge, Cambridge University Press, 2011, p. 332.

25 A pesar de que hubo oposición a nivel interno, después de la Segunda Guerra Mundial los Aliados impusieron un nuevo sistema constitucional en Japón. N. Kawagishi, “The birth of judicial review in Japan”, en International Journal of Constitutional Law 5 (2) 2007.

26 En Austria, la Constitución de 1929 y la Corte Constitucional fueron reintroducidas con pocos cambios en 1945. Thornhill, A Sociology of Constitutions, op. cit., p. 337.

27 La Corte Constitucional yugoslava de esta época tuvo una influencia limitada. M. Cappelletti, "Judicial review in comparative perspective", California Law Review, pp. 1017, 1039.

28 Ackerman, "The rise of world constitutionalism", op. cit.

29 Para mayor información, véase A. Stone, The Birth of Judicial Politics in France: The Constitutional Council in Comparative Perspective, New York, Oxford University Press, 1992. 
gica también es parte de esta coyuntura. ${ }^{30}$ Fuera de Europa, los procesos de descolonización y otros factores allanaron el camino a importantes cambios constitucionales, como la Carta Nacional de Libertades de la India (1950). A fines de la década de los cincuenta, la Corte Suprema de la India amplió el alcance de la protección de los derechos. ${ }^{31}$ Otros tribunales, que operaban en entornos mucho menos estables, tenían una influencia equilibrante sobre las élites gobernantes en sus jurisdicciones. ${ }^{32}$

La caída del muro de Berlín en 1989 constituye el segundo golpe de la primera ola. Y en el centro de todo esto se halla un esfuerzo enorme de democratización constitucional de Europa del este. ${ }^{33}$ El final de la era comunista llevó a las democracias recién constituidas a adoptar constituciones basadas en el modelo kelseniano. ${ }^{34}$ Polonia (que adoptó el control constitucional mediante legislación de 1985), ${ }^{35}$ Hungría (que estableció un tribunal constitucional en 1989), ${ }^{36}$ Eslovaquia (1991), ${ }^{37}$ República Checa (1993), ${ }^{38}$ Lituania (1992), ${ }^{39}$ Estonia (con un modelo descentralizado en 1993), ${ }^{40}$ Bulgaria (con un tribunal constitucional que comenzó a funcionar en 1991), ${ }^{41}$ Rumania (que estableció un tribunal constitucional en 1991 ${ }^{42}$ y Ucrania son ejemplos centrales. ${ }^{43}$ Rusia es un ejemplo

$30 \quad$ Para un discusión sobre la introducción del control constitucional en Bélgica, véase Gardbaum, "Separation of Powers and the Growth of Judicial Review in Established Democracies (or Why Has the Model of Legislative Supremacy Mostly Been Withdrawn From Sale?", op. cit., p. 619. Sin embargo, nótese que democracias como Dinamarca y Finlandia lo hacen incluso sin control constitucional (como también lo hizo Gran Bretaña durante mucho tiempo).

31 V. Sripati, "Toward fifty years of constitutionalism and fundamental rights in India: Looking back to see ahead (1950-2000)", en American University International Law Review 14 (2) (1998), p. 413.

32 T. Ginsburg y A. Simpser (eds.), Constitutions in Authoritarian Regimes, Cambridge, Cambridge University Press, 2013.

33 Véase B. Ackerman, "The rise of world constitutionalism", op. cit.; T. Ginsburg, G. A. Caldeira, R. D. Kelemen y K. E. Whittington, "The global spread of constitutional review", en Oxford Handbook of Law and Politics, Oxford, Oxford University Press, 2008, p. 82; S. Holmes y C. R. Sunstein, "The politics of constitutional revision in Eastern Europe", en S. Levinson (ed.), Responding to Imperfection. The Theory and Practice of Constitutional Amendment, Princeton, Princeton University Press, 1995; W. Sadurski, Rights Before Courts, op. cit., p. 275.

34 Estonia no lo hizo, sin embargo. N. Maveety y V. Pettai, "Government lawyers and non-judicial constitutional review in Estonia", en Europe-Asia Studies 57 (1) (2005), pp. 93, 99.

35 M. F. Brzezinski y L. Garlicki, "Judicial review in post-communist Poland: The emergence of a Rechtsstaat", en Stanford Journal of International Law 31 (1995), p. 13.

36 G. Halmai, "The reform of constitutional law in Hungary after the transition", en Legal Studies 18 (2) (1998), pp. 188, 189; A. Sajó, "Reading the invisible constitution: Judicial review in Hungary", en Oxford Journal of Legal Studies 15 (2) (1995), pp. 253, 254-255.

37 D. Malová, "the role and experience of the Slovakian Constitutional Court", en Constitutional Justice, East and West: Democratic Legitimacy and Constitutional Courts in Post-Communist Europe in a Comparative Perspective 62 (2002), p. 349.

38 Una versión limitada del control constitucional fue introducida en República Checa antes de la Primera Guerra Mundial. Véase Sadurski, Rights Before Courts, op. cit., pp. 4-5.

39 L. Sabaliunas, "Comparative perspectives on judicial review in Lithuania", en Europe-Asia Studies 48 (5) (1996), pp. 783, 784 .

40 R. Maruste y H. Schneider, "Constitutional review in Estonia-Its principal scheme, practice and evaluation", en R. Müllerson, M. Fitzmaurice y M. Andenas (eds.), Constitutional Reform and International Law in Central and Eastern Europe, Leiden, Brill, 1998, pp. 91, 91-92.

41 H. Schwartz, The struggle for constitutional justice in post-communist Europe, Chicago, University of Chicago Press, 2000, p. 172.

42 P. Blokker et al., "Constitution making in Romania: from reiterative crises to Constitutional moment", en

$258 \quad 43 \quad$ Revista Română de Drept Comparat 02 (2012), pp. 187, 189-190. West: Democratic Legitimacy and Constitutional Courts in Post-Communist Europe in a Comparative Perspective 62 (2002), pp. 327, 329. 
un poco más complicado. ${ }^{44}$ Otro escenario central de cambios constitucionales en este periodo es el este de Asia con cambios dramáticos en Indonesia, Tailandia, Corea del Sur, Taiwán y Mongolia desde la década de los ochenta en adelante. ${ }^{45}$ Sudáfrica es también un ejemplo importante e influyente (1996). ${ }^{46}$ De hecho, las fechas durante las cuales se adoptaron las constituciones no son necesariamente la evidencia más confiable para dar cuenta de procesos constitucionales genuinos. Estos son procesos complicados con diferentes grados de estabilidad para cada ordenamiento. ${ }^{47}$ No obstante, es difícil rechazar la tendencia general hacia un mayor uso del control constitucional como una clara tendencia de la segunda mitad del siglo XX. ${ }^{48}$ También existe una tendencia innegable entre los académicos a celebrar este proceso como una marcha continua hacia un mundo mejor. El principal debate académico no versa sobre si este proceso ocurrió y si es un desarrollo positivo, sino sobre por qué y cómo ocurrió y si apunta a una convergencia entre los sistemas legales o hacia una mayor pluralidad y simultánea convergencia. ${ }^{49}$ Para nuestra discusión, aquí es importante reiterar la dinámica dialéctica que caracteriza este proceso y desafiar sus matices a menudo progresistas. Discutiremos algunos de estos desarrollos en nuestro análisis de la tercera ola. ${ }^{50}$

\section{La segunda ola - Las dimensiones internacional y transnacional}

La segunda ola sigue un proceso gradual de crecimiento del derecho internacional y las instituciones internacionales en el mundo contemporáneo. Este proceso fue paralelo a la primera ola, ganó terreno hacia fines del siglo XIX $\mathrm{y}$, más profundamente, en el periodo de entreguerras, pero aquí también las secuelas de la Segunda Guerra Mundial y el periodo que siguió a la Guerra

$44 \quad$ A. Trochev, "Less democracy, more courts: a puzzle of judicial review in Russia”, en Law E Society Review 38 (3) (2004), p. 513. Para mayor información sobre el control constitucional en Europa Central y del Este, véase M. Rosenfeld, W. Sadurski y R. Toniatti, "Central and Eastern European constitutionalism a quarter century after the fall of the Berlin Wall: Introduction to the Symposium", International Journal of Constitutional law 13 (2015), p. 119.

45 J. Chu, "Global constitutionalism and judicial activism in Taiwan", en Journal of Contemporary Asia 38 (4) (2008), p. 515; T. Ginsburg, "Constitutional Courts in East Asia: Understanding variation", en J. Comp. L. 3 (2008), p. 80. Para mayor información, véase T. Ginsburg, “Confucian constitutionalism? The emergence of constitutional review in Korea and Taiwan", en Law \& Social Inquiry 27 (4) (2002), p. 763.

46 Constitución de la República de Sudáfrica, 1996.

47 Para más información sobre el cambio en el creciente escepticismo en Europa Central y del Este, véase Rosenfeld, Sadurski y Toniatti , "Central and Eastern European constitutionalism a quarter century after the fall of the Berlin Wall: Introduction to the Symposium", op. cit., p. 119.

48 Tom Ginsburg documenta algunas de estas tendencias en el Comparative Constitutions Project, https://comparativeconstitutionsproject.org/ccp-visualizations/. Para una revisión de este proceso y otros relacionados, véase D. S. Law y M. Versteeg, "The evolution and ideology of global constitutionalism”, en California Law Review 99 (2011).

49 Sobre esta controversia y cómo debe ser solucionada, véase R. Dixon y E. A. Posner, "The limits of constitutional convergence", Chinese Journal of International Law 11 (2010).

50 Sobre las diferentes perspectivas sobre la cuestión de la convergencia, véase ibid. Para diferentes aspectos de la divergencia que pueden estar relacionados con la reacción negativa a estos procesos, véase S. Gardbaum, "Are strong constitutional courts always a good thing for new democracies", en Columbia Journal of Transnational Law 53 (2014). 
Fría son dos hitos destacables. Si bien el derecho internacional tradicional se fundamentaba en acuerdos bilaterales y objetivos funcionales determinados, la segunda mitad del siglo $\mathrm{XX}$ presenció el surgimiento de propósitos mucho más ambiciosos. La Organización Internacional del Trabajo (OIT) y la Sociedad de las Naciones fueron los precursores de una concepción más sólida de una comunidad internacional. El establecimiento de la Organización de las Naciones Unidas (ONU), el Banco Mundial, el Acuerdo General sobre Aranceles Aduaneros y Comercio (GATT) y el Tribunal Europeo de Derechos Humanos (TEDH) después de la Segunda Guerra Mundial, y más aún mediante la introducción de los diversos tratados de derechos humanos a mediados de la década de los sesenta, dieron lugar gradualmente a visiones globales que proponían una alternativa a la visión estatista del conjunto internacional de Estados a través de la noción de comunidad internacional de personas.$^{51}$ Esta redefinición hizo más convincente y más aceptable la noción según la cual el control constitucional internacional era más que la solución de controversias jurídicas entre los Estados y podría convertirse en la aplicación judicial de las normas internacionales dentro de estos.

La segunda ola, que tiene una serie de ondas "prehistóricas", pero que gana un gran momentum después de la Segunda Guerra Mundial, ${ }^{52}$ es, por lo tanto, el surgimiento del derecho internacional en sentido general, pero también, y aún más importante, de los regímenes de tratados internacionales como el Convenio Europeo de Derechos Humanos, la Convención Interamericana de Derechos Humanos, los convenios de Ginebra, etc. E incluso más relevante fue el surgimiento de organismos internacionales como la UE como fuente de derecho superior que utilizan los tribunales estatales y los tribunales internacionales en el ejercicio de su poder de control constitucional.

El control de constitucionalidad de segunda ola se lleva a cabo en dos niveles. A nivel internacional, los actos y las acciones de los Estados pueden ser objeto de escrutinio ante los "grandes" tribunales internacionales como la Corte Mundial, el TEDH, la Corte Interamericana de Derechos Humanos (Corte IDH), los paneles de la Organización Mundial del Comercio (OMC) y la Sala de Apelaciones, el Tribunal Internacional del Derecho del Mar (ITLOS), la CPI y otros. Es exagerado llamar a estos procesos solución de "controversias". Son, de facto o de jure, un fenómeno de control constitucional por parte de órganos jurisdiccionales transnacionales e internacionales.

51 Para una discusión sobre el concepto del Derecho Internacional como comunidad, véanse U. Fastenrath et al. (eds.), From Bilateralism to Community Interest: Essays in Honour of Bruno Simma, Oxford, Oxford University Press, 2011; J.H.H. Weiler, "The geology of international law-governance, democracy and legitimacy", en ZaöRV, 64 (2004).

52 D. Kennedy, "The move to institutions", en Cardozo Law Rev. (8) (1986); M. Mazower, Governing the World: The History of an Idea, 1815 to the Present, New York, Penguin Books, 2013; S. Moyn, The Last Utopia: Human Rights in History, Cambridge, Belknap Press: An Imprint of Harvard University Press, 2012; A. W. B. Simpson, Human rights and the end of empire: Britain and the genesis of the European Convention, Oxford, Oxford University Press, 2004. 
Salvo una excepción que abordaremos en breve, el número de casos en los que un Estado se encuentra ante un tribunal internacional no es muy alto. Es suficiente anotar que el número de casos es bastante limitado en comparación con sus contrapartes nacionales (incluso el Tribunal de Justicia europeo no es una excepción si comparamos el número de casos de acciones directas contra un Estado miembro con el número de fallos preliminares). En cambio, el impacto jurídico más importante está en la función judicial de establecimiento o determinación de normas y la forma en la que la jurisprudencia nacional se nutre de estas. La jurisprudencia de los tribunales internacionales, incluso si es cuantitativamente limitada, da forma a las normas internacionales $\mathrm{y}$, por lo tanto, tiene un efecto de desbordamiento que alcanza los sistemas jurídicos nacionales e internacionales. Sin embargo, su influencia en la administración diaria de justicia y en el destino de las personas sigue siendo bastante marginal, con la notable excepción de la UE. Incluso, el impacto de la CEDH y la Corte IDH es más normativo que el campo de la administración de justicia individual de hoy en día.

A nivel internacional, el fenómeno más llamativo se encuentra en el mundo del arbitraje de inversiones y es la participación de los tribunales internacionales en el control constitucional o judicial de acciones estatales, tanto legislativas como administrativas. ${ }^{53}$ Se trata de un fenómeno que ha crecido exponencialmente desde la década de sesenta en adelante y que comprende miles de tratados y cientos de casos que se presentan ante tribunales internacionales de inversión que ejercen control sobre los actos estatales. ${ }^{54}$ Uno no se debe dejar distraer con la noción de tribunales de inversión. El objeto de estas controversias no se refiere únicamente a asuntos referentes a la expropiación. En el núcleo de muchas de estas disputas se encuentra el Estado social y regulatorio que afecta el medio ambiente, el suministro de agua y la prohibición de materiales nocivos. En otras palabras, casos difíciles y socialmente sensibles. Sin embargo, el mundo de los tribunales de inversión solo está indirectamente relacionado con la segunda ola. Los tribunales de inversión, en efecto, ejercen un control constitucional de facto sobre las políticas públicas de los Estados; sus decisiones disminuyen el espacio público local y las percepciones locales del interés público. Sería difícil explicar la importante resistencia que actualmente se da contra el arbitraje de conflictos inversor-Estado (ISDS, por sus siglas en inglés) si esto no fuera así. ${ }^{55}$ Hasta cierto punto, los procedimientos ante

53 Fastenrath et al., From Bilateralism to Community Interest, op. cit., p. 250; Weiler, "The geology of international law-governance, democracy and legitimacy", op. cit.

54 Para más información, vénase P. Egger y V. Merlo, “BITs bite: An anatomy of the impact of bilateral investment treaties on multinational firms", en The Scandinavian Journal of Economics 114 (4) (2012); K. P. Sauvant, "The rise of international investment, investment agreements and investment disputes", en K. P. Sauvant y M. Chiswick-Patterson (eds.), Appeals Mechanism in International Investment Disputes, Oxford, Oxford University Press, 2008, p. 3.

55 G. V. Harten, Investment Treaty Arbitration and Public Law, Oxford, Oxford University Press, 2008; B. Kingsbury y S. W. Schill, "Investor-state arbitration as governance: fair and equitable treatment, proportionality and the emerging global administrative law", en A. J. Berg (ed.), 50 Years of the New York Convention: ICCA International Arbitration Conference, Alphen aan den Rijn, Kluwer Law International, 2009; D. Schneiderman, 
los tribunales de arbitraje de inversión reflejan la lógica del control de constitucionalidad: el actor privado individual es el actor poderoso que disfruta de la protección de su Estado a través del vehículo del tratado bilateral de inversión (BIT), mientras que el Estado donde se lleva a cabo la inversión puede encontrarse en una posición de impotencia. ${ }^{56}$ Existe también todo un universo de acuerdos comerciales regionales -alrededor de 500 en todo el mundo-que abarcan mucho más que el comercio, desde lo bilateral hasta lo multilateral, y que también proporcionan, en ocasiones, varios modelos de procedimientos judiciales obligatorios (como el Tratado de Libre Comercio de América del Norte, o NAFTA) y los cuales aportan una enorme producción legislativa y regulatoria a los espacios legales internacionales y nacionales.

Pero a pesar de las impresiones, los tribunales nacionales -héroes a los ojos de algunos, villanos a los ojos de otros- resultan ser mucho más interesantes en la segunda ola y son sus protagonistas principales. La importancia de estos surgió a medida que más y más tribunales estaban dispuestos a utilizar el derecho internacional como fuente de obligaciones vinculantes que podían ser invocadas por los individuos. ${ }^{57}$ No es solo su ubicuidad y accesibilidad como parte de los sistemas jurídicos domésticos, sino el hecho de que las obligaciones internacionales tienen más dientes debido a su mayor exigibilidad judicial dentro de los Estados en los que operan, lo que las hace aún más importantes..$^{58}$

Por supuesto, en algunos Estados monistas las normas internacionales en principio eran vinculantes, pero Eyal Benvenisti demostró que, durante mucho tiempo, los tribunales nacionales eran expertos en evitar su aplicación. ${ }^{59}$ La esencia de la segunda ola fue la aceptación de las normas jurídicas internacionales como jerárquicamente superiores $\mathrm{y}$, por lo tanto, como la base del control constitucional de los tribunales nacionales. ${ }^{60}$

Constitutionalizing Economic Globalization: Investment Rules and Democracy's Promise, Cambridge, Cambridge University Press, 2008. Para mayor información sobre la marginalización de los intereses locales por parte de los regímenes de gobernanza, véase S. Battini, "The procedural side of legal globalization: The case of the World Heritage Convention", en International Journal of Constitutional Law 9 (2) (2011); E. Benvensiti y G. W. Downs, "Democratizing courts: How national and international courts promote democracy in an era of global governance", en NYU Journal of International Law \& Politics 46 (2013), pp. 745-752.

56 Para un intento de contrarrestar estas relaciones de poder, véase Government of Canada, Department of Global Affairs, Trade, and Investment, Canada's Enhanced Corporate Social Responsibility Strategy (CSR) to Strengthen Canada's Extractive Sector Abroad.

57 E. Benvenisti y G. W. Downs, "National courts, domestic democracy, and the evolution of international law", European Journal of International Law 20 (1) (2009).

58 R. A. Falk, "The role of domestic courts in the international legal order", en Indiana Law Journal 39 (1963); J. H. H. Weiler, "The transformation of Europe", en Yale Law Journal (1991).

59 Eyal Benvenisti, “Judicial misgivings regarding the application of International Law: An analysis of attitudes of National Courts", en European Journal of International Law 4 (1993).

60 Andre Nollkaemper se ha concentrado en estos procesos desde una perspectiva teórica diferente: “La imagen que emerge es una en la que el derecho internacional, por un lado, llega cada vez más a los tribunales nacionales, y, por otro lado, muchos estados y sus tribunales se acercan cada vez más a este para permitir que el derecho internacional guíe sus prácticas judiciales". Véase M. Zurn, A. Nollkaemper y R. Peerenboom, Rule of law dynamics: in an era of international and transnational governance, Cambridge, Cambridge University Press, 2012. 
La jurisprudencia de los derechos humanos es un campo jurídico importante para demostrar que, en efecto, hubo una segunda ola de control de constitucionalidad. Las jurisprudencias interna e internacional sobre derechos humanos son frecuentemente complementarias y compatibles, lo que facilita su uso por tribunales nacionales e internacionales. ${ }^{61}$ Los tribunales constitucionales pueden referirse a las normas internacionales como base para su control constitucional a través de criterios interpretativos, incluso si tales normas no están completamente ratificadas en el sistema jurídico nacional. Al mismo tiempo, los tribunales internacionales hacen uso de las leyes nacionales como criterio hermenéutico. En otros contextos, dicha referencia a la norma internacional, según la definen los tribunales internacionales, es requerida por la arquitectura de la relación entre los poderes judiciales nacionales e internacionales. La relación entre los tribunales nacionales europeos y el ECJ es un ejemplo en este sentido. ${ }^{62}$

De este análisis se sigue que no estamos en desacuerdo con la opinión que considera a los tribunales internacionales como los actores clave en la segunda ola ${ }^{63}$ y que considera a los nacionales como órganos judiciales tan importantes e influyentes como los internacionales. Eyal Benvenisti demostró cómo los tribunales nacionales, en una variedad de contextos, han llegado a utilizar el derecho internacional como base para establecer obligaciones estatales a individuos..$^{64}$ La accesibilidad a los tribunales nacionales facilita su influencia en comparación con la de los tribunales internacionales. Además, las cortes domésticas tienen mecanismos de aplicación más efectivos del derecho internacional, lo que las posiciona como superiores a los órganos judiciales internacionales. Por supuesto, existe una variedad de parámetros o supuestos de poder para que estos desarrollos puedan tener lugar. Para dar solo un ejemplo, Karen Alter ha demostrado de manera brillante cómo dentro del universo de la UE, los tribunales nacionales de inferior jerarquía defienden con gusto este rol judicial internacional en casa como un medio de autoempoderamiento dentro de la jerarquía judicial nacional..$^{65}$

Finalmente, para nosotros, los fenómenos descritos como constitucionalismo global, pluralismo constitucional y espacio administrativo global, son parte de la segunda ola en la expansión global del control constitucional y no una nueva ola, ontológicamente hablando. Si se observa con detenimiento, la esencia del

61 W.-C. Chang y J. R. Yeh, "Internationalization of Constitutional Law”, en M. Rosenfeld, A. Sajó (eds.), The Oxford Handbook of Comparative Constitutional Law, Oxford, Oxford University Press, 2012, p. 1167.

62 A. M. Slaughter, A. S. Sweet y J. Weiler, The European Court and National Courts: Doctrine \& Jurisprudence: Legal Change in Its Social Context, London, Bloomsbury Publishing, 1998.

63 Ver, por ejemplo, B. Fassbender, "The United Nations Charter as Constitution of the International Community", Columbia Journal of Transnational Law 36 (3) (1998).

64 E. Benvenisti, "Reclaiming democracy: The strategic uses of foreign and international law by national courts", American Journal of International Law 102 (2) (2008).

65 K. J. Alter, Establishing the supremacy of European law: The making of an international rule of law in Europe, Oxford, Oxford University Press, 2010. 
constitucionalismo global se compone principalmente del uso de las normas internacionales de orden superior dentro de los Estados (en otros términos, la expansión intrínseca de los fenómenos que forman parte de la segunda ola, de hecho, hace parte de su definición y ontología). La segunda ola, en su forma original y como ha sido tratada en la literatura durante muchas décadas, se refiere al uso de normas derivadas de tratados internacionales negociados por los Estados y, muy a menudo, ratificados por los parlamentos nacionales como fuente de normatividad. Sin embargo, la fuente empírica más reciente y enormemente significativa de dicha normatividad no son las disposiciones específicas de los tratados, sino el producto de lo que a veces se ha llamado gobernanza internacional y transnacional, el derecho administrativo global o internacional, promulgado por funcionarios públicos internacionales y nacionales que da lugar al derecho administrativo global (GAL, por sus siglas en inglés). El GAL, y su recepción en la legislación nacional, da lugar a un nuevo conjunto de cuestiones sociales, políticas y normativas igualmente problemáticas cuando los tribunales nacionales o domésticos lo utilizan como una fuente en sede de control constitucional, pero también cuando se abstienen de usarlo. Aun así, aunque el contenido y los desafíos de la segunda ola eran bastante diferentes de 1950 a 1970 frente a 1980 al año 2000, en nuestra opinión estos permanecen en el mismo universo.

\section{La primera y segunda olas: fundamento(s) y explicación(es)}

\section{Fundamento(s)}

El surgimiento de la primera y la segunda olas es un fenómeno histórico intrigante. Como sugiere el siguiente análisis, académicos jurídicos, historiadores, científicos sociales y filósofos intentaron proporcionar diferentes fundamentos cuando estas aparecieron.

La justificación o narrativa comunes para el surgimiento de la primera ola del control de constitucionalidad es la tesis de la catástrofe asociada con las lecciones que dejó la Segunda Guerra Mundial. La catástrofe transformó el orden constitucional en Alemania (1949), Italia (1948) y Japón (1947), y la transición democrática después de la dictadura en España (1978) y Portugal (1982). Luego de esto, la catástrofe también transformó y dio origen a las transiciones en América Latina y, por supuesto, a las transiciones de los regímenes comunistas hacia la democracia en Europa del Este. ${ }^{66} \mathrm{El}$ control constitucional estaba destinado a remediar, verificar y restringirle a la legislatura el uso de su poder

$66 \quad$ Ackerman, "The Rise of World Constitutionalism”, op. cit. 
contra las minorías y en violación de los derechos individuales. ${ }^{67}$ John Ferejohn y Pasquale Pasquino, por dar tan solo un ejemplo, explican cómo el fracaso del legislador y del poder judicial allanaron el camino al modelo centralizado de control constitucional en Alemania e Italia. El modelo centralizado posicionó a los tribunales constitucionales como independientes tanto de la legislatura (pues estaban autorizados para expulsar legislación del ordenamiento jurídico), como del poder judicial (pues estaban separados del sistema judicial no constitucional). ${ }^{68}$ Como señala Stephen Gardbaum:

\begin{abstract}
El evidente y catastrófico fracaso del modelo de supremacía legislativa del constitucionalismo para prevenir las tomas del poder totalitarias y las violaciones de derechos humanos a gran escala antes y durante la Segunda Guerra Mundial, significó que, casi sin excepción, cuando surgió la ocasión para que un país empezara de cero y promulgara una nueva constitución, se adoptaran muchos de los elementos esenciales del modelo estadounidense, el cual era completamente opuesto [...] País tras país fueron abandonando la supremacía legislativa y transitaron hacia una carta de derechos suprema e inamovible, carta de derechos que se aplicó judicialmente (o cuasi judicialmente). ${ }^{69}$
\end{abstract}

De hecho, Alemania e Italia sirvieron como precursores importantes de lo que Loraine E. Weinrib denominó el "paradigma de la posguerra" ${ }^{70}$ En este paradigma de posguerra, las cortes son las "guardianas especiales de los principios constitucionales fundacionales, incluido el estado de derecho, la separación de los poderes, la democracia, y los derechos específicos que garantiza la constitución", pero, y a pesar de ese mandato amplio, no "entran con prerrogativas políticas, sino que contienen [...] [a los] organismos electos a su mandato electoral", cuyos límites se encuentran en la constitución. ${ }^{71}$

En 1980, John Hart Ely publicó Democracy and Distrust, donde presentó una teoría revisada y más contemporánea del control constitucional que no necesitaba como su fundamento la existencia de dictaduras o catástrofes. Ely capturó el significado del control judicial y lo entendió como un medio para corregir las fallas propias de la representación democrática en la protección de los derechos de las minorías contra la amenaza de las mayorías:

Llegamos a reconocer que los dispositivos constitucionales existentes para proteger a las minorías simplemente no eran suficientes. Ninguna lista finita de derechos puede cubrir todas las formas en las que las mayorías pueden tiranizar a las mino-

67 Ibid.; M. Cappelletti, The Judicial Process in Comparative Perspective, Oxford, Oxford University Press, 1989; R. Hirschl, Towards Juristocracy: The Origins and Consequences of the New Constitutionalism, Cambridge MA, Harvard University Press, 2004; D. P. Kommers y R. A. Miller, The Constitutional Jurisprudence of the Federal Republic of Germany, op. cit.; B. A. Simmons, Mobilizing for Human Rights: International Law in Domestic Politics, Cambridge, Cambridge University Press, 2009.

68 Ferejohn y Pasquino, “Constitutional adjudication”, op. cit.

69 Gardbaum, "The New Commonwealth model of Constitutionalism", op. cit., pp. 714-715.

70 Weinrib, "The postwar paradigm and American exceptionalism", Legal Studies Research Paper, 899131 (2006), pp. $89-90$.

$71 \quad$ Ibid., p. 92. 
rías y tampoco se puede contar con los mecanismos informales y más formales del pluralismo [...] La teoría existente de la representación tuvo que extenderse para garantizar, no simplemente que el representante no separara sus propios intereses de los de la mayoría de su electorado, sino también para que no separaran los intereses de la coalición mayoritaria de las de varias minorías. ${ }^{72}$

Así,

... al menos en algunas situaciones la intervención judicial se vuelve apropiada cuando los procesos existentes de representación parecen inadecuadamente ajustados a la luz de la representación de los intereses minoritarios, incluso los intereses minoritarios que no son representativos en términos de $\operatorname{votos}^{73}[\ldots]$ los tribunales, como instituciones expertas en procesos y, más importante todavía, ajenos a la arena política, pueden afirmar con seguridad estar mejor calificados y situados para cumplir estas funciones que los funcionarios políticos. ${ }^{74}$

Creemos que, de alguna forma u otra, la tesis de Ely subyace en muchos regímenes actuales de control constitucional que operan al interior de democracias funcionales.

La narrativa del Estado totalitario personifica más claramente el caso de las mayorías que amenazan irrazonablemente los derechos de las minorías. Pero los problemas incrustados en un Estado poderoso, que usa su autoridad para socavar los derechos individuales, ya eran centrales para el desarrollo del control constitucional administrativo contra las burocracias. Por lo tanto, una razón fundamental para la adopción del control constitucional tanto en el derecho administrativo como en el constitucional gira en torno a la necesidad de restringir los amplios poderes del Estado a través de la protección de los derechos con el fin de remediar las relaciones de poder desequilibradas entre este y el individuo. Como lo señaló Ran Hirschl en su estudio comparativo, el control constitucional a menudo

... conceptualiza el propósito de los derechos como la protección de la esfera privada (humana y económica) de la interferencia de la esfera "colectiva" (a menudo entendida como el Estado y sus instituciones reguladoras). Por lo tanto, los tribunales supremos nacionales de estos países tienden a considerar la regulación estatal como una amenaza a la libertad y la igualdad, incluso más que las relaciones e instituciones sociales potencialmente opresivas y explotadoras del llamado sector "privado". ${ }^{75}$

72 J. H. Ely, Democracy and distrust: A theory of judicial review, Cambridge MA, Harvard University Press, 1980, pp. 81-82.

73 Ibid., p. 86.

74 Ibid., p. 88. Véase también R. H. Jr. Fallon, "The core of an uneasy case for judicial review", en Harvard Law

266 Review 121 (7) (2007); M. Kumm, "Institutionalising socratic contestation: the rationalist human rights para-
digm, legitimate authority and the point of judicial review", en Eur. J. Legal Stud. 1 (2007).
$75 \quad$ R. Hirschl, "Negative Rights vs. Positive Entitlements: A comparative study of judicial interpretations of

266 Review 121 (7) (2007); M. Kumm, "Institutionalising socratic contestation: the rationalist human rights para-
digm, legitimate authority and the point of judicial review", en Eur. J. Legal Stud. 1 (2007).
R. Hirschl, "Negative Rights vs. Positive Entitlements: A comparative study of judicial interpretations of rights in an emerging neo-liberal economic order", Hum. Rts. Q. 22 (2000), p. 1095. 
Las explicaciones ideológicas que siguen a la tesis de la catástrofe tienden a romantizar los orígenes del control constitucional. Este se concibe comúnmente como el producto de un desarrollo evolutivo y progresivo. Es la historia de una adopción casi universal del control constitucional el día después de la guerra que, a su vez, se concibe como una victoria del diseño constitucional occidental. Como señaló Tom Ginsburg: "sin duda, el desempeño real del control constitucional varió, dependiendo de las circunstancias políticas locales, pero los tribunales exitosos fueron emulados y se convirtieron en un ideal al que otros aspiraban". ${ }^{76}$ Tales explicaciones acerca del origen del control de constitucionalidad pueden ser matizadas, complementadas o incluso desafiadas por una explicación menos romántica de la primera ola: teorías o explicaciones llamadas por la doctrina "hegemónica, funcionalista y estratégica".

Una perspectiva hegemónica se centraría en el papel y la influencia de los policy makers y pensadores estadounidenses en los procesos de constitucionalización en la Europa de la posguerra. ${ }^{77}$ Las narrativas funcionalistas atribuyen el auge del control constitucional a la estructura fragmentada de la gobernanza, especialmente en sistemas federales como Estados Unidos. ${ }^{78}$ Otras explicaciones funcionalistas exploran cómo el control constitucional facilita una mayor coherencia y eficiencia. ${ }^{79}$ Otras demuestran cómo el control constitucional puede servir potencialmente como una herramienta de resolución de conflictos en sociedades divididas: "En las sociedades divididas, debido a la existencia de un conflicto o a la falta de una existencia compartida, la constitución es a menudo el vehículo principal para forjar una identidad política común, que es, a su vez, necesaria para que ese régimen constitucional funcione" ${ }^{\prime 80}$

El surgimiento de un Estado regulador y el aumento de los problemas relacionados con la información asimétrica proporcionan otra explicación funcionalista para la introducción del control constitucional. De acuerdo con este conjunto de explicaciones, el control constitucional está destinado a exponer cómo la legislación influye en la vida de quienes están sujetos a ella y a verificar el desempeño problemático del Estado burocrático. ${ }^{81}$ Siguiendo una línea funcionalista similar, el control constitucional podría mejorar la credibilidad

76 T. Ginsburg y A. Simpser (eds.), Constitutions in Authoritarian Regimes, op. cit., p. 87.

77 Véase, por ejemplo, U. Greenberg, The Weimar Century: German Émigrés and the Ideological Foundations of the Cold War, Princeton, Princeton University Press, 2015, pp. 191-377.

78 Para más información sobre la tesis de la fragmentación, véase J. Ferejohn, “Judicializing Politics, Politicizing Law", en Law and Contemporary Problems 65 (3) (2002).

79 M. Shapiro, "The success of judicial review in constitutional dialogues in comparative perspective", en S. J. Kenney, W. M. Reisinger y J. C. Reitz (eds.), Constitutional Dialogues in Comparative Perspective, London, Palgrave Macmillan UK, 1999.

80 Véase S. Choudhry, "Bridging comparative politics and comparative constitutional law: Constitutional design in divided societies", en S. Choudhry (ed.), Constitutional Design for Divided Societies: Integration or Accommodation?, Oxford, Oxford University Press, 2008. Sobre las cortes como desarrolladores de negociaciones ético-políticas, véase R. Pildes, "Ethnic identity and democratic institutions: A dynamic perspective", en S. Choudhry (ed.), Constitutional Design for Divided Societies: Integration or Accommodation?, Oxford, Oxford University Press, 2008, pp. 195-198.

81 M. Shapiro y A. S. Sweet, On Law, Politics, and Judicialization, Oxford, Oxford University Press, 2002. 
de los compromisos. ${ }^{82}$ David Law demostró el beneficio del control constitucional para los Estados que desean atraer mano de obra altamente calificada:

... el respeto por los derechos humanos [...] puede ayudar a los Estados a desarrollar y atraer a mano de obra calificada de la misma manera en la que el respeto de la propiedad privada ayuda a atraer y a acumular capital [...] Políticas constitucionales favorables, tales como la libertad religiosa o el derecho a expresar la opinión sin miedo a ser reprendido, o la libertad para disfrutar la última película o novela, constituyen un incentivo no económico para que los trabajadores quieran quedarse o mudarse allá un estado específico. ${ }^{83}$

Las explicaciones estratégicas desagregan las instituciones del Estado y examinan las circunstancias políticas específicas en las que surge el control constitucional. ${ }^{84}$ Autores como Ran Hirschl y Tom Ginsburg explicaron la adopción del control constitucional como una elección estratégica de las élites que buscan sostener su influencia e intereses a la luz de su previsible declive. ${ }^{85}$ Tales explicaciones estratégicas prevalecen particularmente en el contexto de las transiciones constitucionales del autoritarismo a la democracia, donde el establecimiento de tribunales constitucionales tiene como objetivo restringir el poder antidemocrático de las futuras mayorías o protegerse contra la consolidación del poder de un solo partido. ${ }^{86}$ Tal perspectiva estratégica demuestra cómo las minorías organizadas podrían utilizar el control constitucional para mantener y restaurar su influencia en la política nacional. ${ }^{87}$ Los ataques de los gobiernos a los tribunales constitucionales y a los poderes judiciales que discutimos a continuación, exigen una reflexión sobre la explicación estratégica del control constitucional que va más allá del momento en el cual se adopta dicho control. Las élites pueden haber respaldado el control constitucional para asegurar su posición o sus preferencias políticas en los momentos constitucionales fundamentales, pero, como demuestran los desarrollos de la tercera ola, pueden abandonarla por completo en una etapa posterior.

El fundamento común del control constitucional de la segunda ola se basa en las sensibilidades cosmopolitas de los derechos humanos y es principalmente una explicación vinculada a un ideario. Los gobiernos promueven los derechos humanos a nivel internacional porque son consistentes con sus propios

82 B. R. Weingast, "Constitutions as governance structures: The political foundations of secure markets", en Journal of Institutional and Theoretical Economics (JITE)/Zeitschrift für die gesamte Staatswissenschaft (1993).

83 D. S. Law, "Globalization and the future of constitutional rights", en Nw. UL Rev. 102 (2008), pp. 1322-1323.

84 T. Ginsburg, "Economic analysis and the design of constitutional courts", en Theoretical Inquiries in Law 3 (1) (2002); R. Hirschl, "The strategic foundations of constitutions", en D. J. Galligan y M. Versteeg (eds.), Social and Political Foundations of Constitutions, Cambridge, Cambridge University Press, 2013, pp. 162-163.

85 T. Ginsburg, "Economic analysis and the design of constitutional courts", op. cit.; Hirschl, "The Strategic Foundations of Constitutions", op. cit., pp. 162-163.

$268 \quad 86$ S. Issacharoff, "Constitutional courts and democratic hedging”, en Geo. LJ, vol. 99, 2010.

87 J. Elster, "Forces and mechanisms in the constitution-making process", en Duke Law Journal 45 (1995); Hirschl, Towards Juristocracy, op. cit.; M. Shapiro, Courts: a comparative and political analysis, Chicago University of Chicago Press, 2013. 
valores ${ }^{88}$ Los poderes judiciales internacionales que operan en el contexto de los derechos humanos se conciben fácilmente en términos cosmopolitas como agentes que operan en nombre de la comunidad global. Más allá de la lógica cosmopolita, los realistas explican el control constitucional de la segunda ola como un ejercicio de poder hegemónico, una herramienta utilizada por las grandes potencias para imponer sus puntos de vista a otras naciones. ${ }^{89}$ Las narrativas institucionalistas demuestran cómo la existencia del control constitucional internacional o el compromiso con las normas internacionales en los sistemas nacionales pueden servir para "asegurar" a los actores nacionales de tal modo que se adhieran a estándares internacionales en un momento determinado frente a futuras alternativas políticas (lo que reduce la incertidumbre política nacional) y como un medio para restringir la discreción del gobierno. ${ }^{90}$ Una forma de ver esto muestra cómo los gobiernos actuales atan las manos de los gobiernos futuros para mejorar la credibilidad de las políticas e instituciones nacionales actuales. ${ }^{91}$ Luego de considerar la relación entre la primera y la segunda olas, Andrew Moravczik demostró cómo Alemania e Italia adoptaron sistemas de control constitucional a nivel nacional e internacional (el $\mathrm{CEDH}$ ) "debido a un fuerte deseo de reforzar el orden democrático" ${ }^{92}$ Marco Duranti enfatizó, de manera similar, la política interna y su influencia en el $\mathrm{CEDH}$, pero desafió el énfasis que Moravczik y Simpson hicieron sobre los gobiernos y actores estatales para incluir, también, el papel preeminente de las organizaciones no gubernamentales (ONG) transnacionales e instituciones que hasta ahora no se habían tenido en cuenta para complicar y enriquecer la historia de los orígenes del CEDH. Duranti admitió que el antitotalitarismo era una preocupación central para los movimientos de unidad europeos, pero subrayó que lo totalitario también implicaba políticas como la planificación, la nacionalización y la limitación de la libertad de expresión y, en ese sentido, exploró cómo la política interna de la posguerra, el conservadurismo británico de libre mercado y el conservadurismo francés moldearon decisivamente el CEDH en el momento de su invención. Del mismo modo, aunque Samuel Moyn se centró en diferentes protagonistas, demostró cómo la integración europea de la posguerra, especialmente la creación de un régimen de derechos humanos, fue un proyecto profundamente conservador. ${ }^{93}$

La explicación de Beth Simmons para el surgimiento de la segunda ola consideró el compromiso con las instituciones internacionales de derechos hu-

88 T. M. Franck, "Legitimacy in the international system", en American Journal of International Law 82 (4) (1988).

89 Véase, por ejemplo, K. N. Waltz, Theory of International Politics, Long Grove, Waveland Press, 2010.

90 A. Moravcsik, "The origins of human rights regimes: Democratic delegation in postwar Europe", en International organization 54 (2) (2000).

91 P. Evans, H. K. Jacobson y R. D. Putnam (eds.), Double-Edged Diplomacy: International Bargaining and Domestic Politics, Berkeley, University of California University Press, 1993.

92 Moravcsik, "The origins of human rights regimes: Democratic delegation in postwar Europe", op. cit., p. 233.

93 M. Duranti, The Conservative Human Rights Revolution: European Identity, Transnational Politics, and the Origins of the European Convention, New York, Oxford University Press, 2017, pp. 215-409. Véase también S. Moyn,

Christian Human Rights, Philadelphia, University of Pennsylvania Press, 2015. 
manos como un medio para movilizar grupos políticos o mejorar la posición de la oposición política. ${ }^{94}$ El potencial movilizador de los compromisos internacionales de derechos humanos puede cumplirse mediante litigios en entornos judiciales internacionales o nacionales. Eyal Benvenisti ofreció una interpretación alternativa al ejercicio del control constitucional de la segunda ola por parte de los tribunales nacionales como un ejercicio de acción colectiva contra la captura de los gobiernos por grupos de interés y como un medio para sostener la democracia y la autoridad de los tribunales dentro del Estado democrático. ${ }^{95}$

\section{Explicación(es): agregando los ejes horizontal y vertical a las explicaciones existentes}

Ahora debemos pasar de los fundamentos a la explicación histórica causal. La noción de "fundamento" a menudo tiene una conexión intrínseca con lo causal: un evento pudo haber sucedido porque los actores relevantes fueron persuadidos por las razones a favor o el fundamento de este evento. Pero no existe una superposición total entre los dos. De hecho, en muchos países con un compromiso mínimo o inexistente con la democracia se encuentran, al menos en apariencia, formas de control constitucional.

Debemos afirmar, desde el principio, que una gran parte de la explicación del surgimiento del control constitucional hunde sus raíces en circunstancias locales específicas y, por lo tanto, las "olas" globales podrían considerarse una mera conexión de los puntos locales.

Pero el mero hecho de que haya circunstancias y explicaciones locales discretas también acentúa la realidad de un fenómeno global que trasciende lo local: el control constitucional se ha vuelto omnipresente en Europa, la mayoría de los países de América, Australia y Nueva Zelanda, y no pocos países en Asia y África. Por lo tanto, el fenómeno global, la realidad empírica de la primera y segunda oleada, pasa a formar parte de la explicación misma.

Como se mencionó, para Cappelletti este desarrollo fue normativamente lineal. Significó progreso. Al principio hubo un gran debate (y en ocasiones una oposición) sobre las credenciales democráticas de una institución (control constitucional) que permitió a unos pocos jueces, a menudo no elegidos democráticamente, dejar de lado la legislación democrática mayoritaria. Sin embargo, en la mayoría de las jurisdicciones, con excepciones ocasionales, el dilema contramayoritario se ha dejado de lado de diversas formas, de modo que ya no cobra importancia, al menos como una fuerza desestabilizadora. 
Las cuestiones normativas han evolucionado; ya no se trata de un conflicto estridente entre legisladores y jueces, sino que, desde una perspectiva global y comparativa, ahora existen cuestiones más delicadas como, por ejemplo, la legitimidad democrática de normas internacionales y su impacto en las identidades nacionales. Además, estos procesos están entrelazados con relaciones complicadas que no son necesariamente lineales, sino más dialógicas y plurales. $^{96}$

Al considerar las diferentes explicaciones se debe prestar atención a un eje horizontal que aborda las formas en que los sistemas judiciales nacionales ejercen influencia entre sí y un eje vertical que aborda la influencia entre las olas, esto es, la forma en la que los procesos en una ola influyen en otra. Horizontalmente, algunos relatos se mueven desde procesos top-down de constitucionalización intencionales, hacia la difusión transfronteriza de ideas ${ }^{97} \mathrm{o}$ el diálogo transjudicial. ${ }^{98}$ Los sociólogos han señalado que tales procesos de convergencia global se derivan del aprendizaje de otros países a través de procesos racionales o sesgos cognitivos menos informados. ${ }^{99}$ Algunos Estados pueden optar por adoptar el control constitucional para convertirse en miembros de una clase prestigiosa o dicha adopción puede hacer parte de procesos de aculturación. ${ }^{100}$ A veces, ciertos Estados o instituciones obligan a otros Estados a adoptar tales modelos. Un conjunto notable de ejemplos son los regímenes poscoloniales o sistemas constitucionales que se establecieron después de la ocupación colonial. ${ }^{101}$ Los incentivos de mercado también pueden influir. Estudios empíricos muestran que estas explicaciones son válidas, pero solo para algunos Estados y solo algunas veces. ${ }^{102}$ De manera similar, el trabajo empírico parece sugerir que las influencias horizontales son más efectivas en el contexto del contenido de las normas, pero mucho menos efectivas como explicaciones que den cuenta de la adopción misma de un modelo de control de constitucionalidad. ${ }^{103}$

96 C. McCrudden, "Common law of human rights?: Transnational judicial conversations on constitutional rights", en Oxford journal of legal studies 20 (4) (2000); A. M. Slaughter, "A typology of transjudicial communication", en U. Rich. L. Rev. 29 (1994).

97 H. Keller y A. S. Sweet (eds.), A Europe of rights: the impact of the ECHR on national legal systems, Oxford, Oxford University Press, 2008.

98 McCrudden, "Common law of human rights?: Transnational judicial conversations on constitutional rights", op. cit.; Slaughter, "A typology of transjudicial communication", op. cit.

99 Z. Elkins y B. Simmons, "On waves, clusters, and diffusion: A conceptual framework", en The Annals of the American Academy of Political and Social Science 598 (1) (2005), pp. 43-44; Law y Versteeg, "The evolution and ideology of global constitutionalism", op. cit., pp. 1173-1174; B. A. Simmons y Z. Elkins, "The globalization of liberalization: Policy diffusion in the international political economy", American political science review 98 (1) (2004), p. 184.

100 Grupos de interés transnacionales o por lo menos al nivel del público masivo. Véase, por ejemplo, R. Goodman y D. Jinks, "How to influence states: Socialization and international human rights law", en Duke lj 54 (2004), pp. 630-638. Allí se describen los tres mecanismos.

101 B. Goderis y M. Versteeg, “Transnational constitutionalism: A conceptual framework”, en D. J. Galligan y M. Versteeg (eds.), Social and Political Foundations of Constitutions, Cambridge, Cambridge University Press, 2013, pp. 105-122.

102 Para una revisión de los mecanismos de difusión constitucional, véase ibid.

103 "Los derechos pueden representar un 'discurso barato', mientras que las instituciones probablemente desarrollen una autoimposición tal que los diseñadores de la constitución deben tratarlas a estas como actores con mucho en juego", Ginsburg y Versteeg, "Why do countries adopt constitutional review?", op. cit. 
Algunos casos, por lo tanto, muestran tendencias de convergencia más claras que otros, pero es difícil cuestionar la existencia de una sensibilidad compartida a favor del control constitucional que acompañó su difusión, un sentido de control constitucional como un Zeitgeist predominante. Probablemente, estas sensibilidades se deriven de la participación de agentes de cambio, que también son jugadores repetidos en los procesos de constitucionalización de este periodo. Es difícil concebir la adopción del modelo kelseniano de tribunales constitucionales simplemente como resultado de procesos políticos internos, aunque estos procesos probablemente sean importantes para determinar cuándo y bajo qué condiciones dicha adopción se vuelve factible para una comunidad política en particular.

Nuestra noción de interacción horizontal y vertical destaca la influencia potencial de otras jurisdicciones, internacionales o nacionales, en los procesos constitucionales internos. Está claro que tiene que haber un impulso considerable como explicación de las influencias horizontales en la literatura sociológica sobre la difusión, la aculturación y los préstamos judiciales. Simplemente sugerimos complementarlos enfatizando la importancia de la interacción entre procesos horizontales y verticales que operan dinámica y dialécticamente. Nuestro modelo relacional opera en los mismos dos ejes: un eje horizontal dentro de cada ola por el cual los desarrollos en una jurisdicción pueden impactar y también ayudar a comprender mejor el significado y la importancia de los desarrollos en otras jurisdicciones dentro de cada ola; y un eje vertical en el que la evolución de una onda puede afectar la evolución de otras ondas. Por ejemplo, en cuanto al efecto horizontal dentro de la primera ola, es incongruente imaginar que con la caída del muro de Berlín y la adopción generalizada de constituciones con un control constitucional robusto, no hubo algún impacto mutuo entre uno y otro evento. Como quiera que sea, para nosotros, observadores de este fenómeno, se trata de un mapa muy diferente si miramos la Europa de, digamos, la década de los cincuenta (con un puñado de países en los que se practicaba el control constitucional) y la Europa de la década de 2000 (en la que solo hay un puñado de países en los que no se practicaba dicho control, al menos de alguna forma). Para seguir con este ejemplo, sería inconcebible que en la Europa de los años noventa se redactaran nuevas constituciones democráticas sin incluir el control constitucional. Hay demasiadas similitudes con el modelo kelseniano básico adoptado por Italia y Alemania en el inicio de la primera ola para imaginar que esto es completamente una coincidencia. Lo mismo ocurre con la visión global en su conjunto. En algunos casos el impacto es explícito y en otros casos se trata del Geist, el espíritu de la época. En muchos países, cuando se llega al proceso de adopción de la constitución, es inconcebible, en términos de construcción del Estado, que al momento de redactar la carta, la posición predeterminada no hubiera sido la inclusión del control constitucional de primera ola (control que, por supuesto, podría haber sido rechazado en el momento de la negociación política y la adopción final del texto constitucional). 
Las relaciones horizontales entre las democracias constitucionales existen además en las etapas posteriores, después de la adopción del control constitucional como modelo preferido. En las últimas décadas hemos sido testigos de una creciente referencia a decisiones constitucionales comparativas de los tribunales nacionales a veces tituladas "diálogo transjudicial": una forma de trasplante legal ${ }^{104} \mathrm{o}$ "migración" de ideas constitucionales. ${ }^{105} \mathrm{Vic}$ ky Jackson, una de las principales expertas en este ámbito, describió este proceso en su libro:

En los últimos años se ha desarrollado un discurso constitucional cada vez más transnacional [...] Cada vez más, los tribunales constitucionales se refieren a las decisiones y razonamientos de otros tribunales constitucionales, no siempre para estar de acuerdo, sino más bien para perfeccionar y mejorar la comprensión de conceptos básicos como la dignidad humana, la igualdad y la libertad en contextos contemporáneos. ${ }^{106}$

Tales diálogos potencialmente empoderan a los tribunales. Eyal Benvenisti y George Downs demostraron cómo los préstamos judiciales pueden concebirse como una acción colectiva entre tribunales que opera para alentar a las cortes de diferentes jurisdicciones a ejercer su poder de control constitucional. ${ }^{107} \mathrm{Al}$ gunos académicos celebran el gran potencial de las redes transnacionales entre tribunales ${ }^{108}$ aunque otros suscitan dudas sobre su existencia y sus beneficios. ${ }^{109}$

En cuanto a la segunda ola, el efecto horizontal es aún más evidente si invocamos, por ejemplo, el universo del arbitraje de inversiones y los acuerdos comerciales regionales. Cada acuerdo de inversión es un acuerdo bilateral entre dos Estados, pero cuando miramos el contenido sustantivo y los mecanismos institucionales, parece que salieran del mismo computador y la mis-

104 A. Watson, Legal Transplants: An Approach to Comparative Law, 2 ed., Athens, University of Georgia Press, 1993.

105 S. Choudhry, "Globalization in search of justification: toward a theory of comparative constitutional interpretation", Ind. Lj 74 (1998); McCrudden, "Common law of human rights?: Transnational judicial conversations on constitutional rights", op. cit.; Slaughter, "A typology of transjudicial communication", op. cit. Para una revisión de la literatura y los 'estudios empíricos' en este campo, véase V. C. Jackson, “Comparative constitutional law: Methodologies", en M. Rosenfeld y A. Sajó (eds.), The Oxford Handbook of Comparative Constitutional Law, Oxford, Oxford University Press, 2012, pp. 58-60.

106 Aquellos a favor: V. C. Jackson, “Comparative constitutional federalism and transnational judicial discour$\mathrm{se}^{\prime}$, International Journal of Constitutional Law 2 (1) (2004); L. Weinrib, “Constitutional conceptions and constitutional comparativism", en V. C. Jackson y M. Tushnet (eds.), Defining the Field of Comparative Constitutional Law, Westport, Praeger, 2002.

107 E. Benvenisti y G. W. Downs, Between Fragmentation and Democracy: The Role of National and International Courts, Cambridge, Cambridge University Press, 2017, cap. 5.

108 Para un análisis del uso estratégico del derecho comparado e internacional por parte de cortes constitucionales, véase H. P. Aust, A. Rodiles y P. Staubach, “Unity or uniformity? Domestic courts and treaty interpretation", Leiden Journal of International Law 27 (1) (2014); Benvenisti, "Reclaiming democracy: the strategic uses of foreign and international law by national courts", op. cit. Este fenómeno demuestra cómo los jueces se consideran como parte de una comunidad por fuera de su propio gobierno, pero no desvirtúa la necesidad que tienen de legitimidad interna para mantener su estabilidad institucional.

109 A. Wiener y P. Liste, "Lost without translation? Cross-referencing and a new global community of courts", Indiana Journal of Global Legal Studies 21 (1) (2014). La aproximación pluralista fue empíricamente analizada en por Law y Chang: "Al menos por el momento, los esfuerzos para caracterizar el comparativismo judicial como una forma de diálogo se entienden mejor como una esperanza para el futuro que como una evaluación precisa de la práctica". D. S. Law y W. C. Chang, "The limits of global judicial dialogue", Washington Law Review 86 (2011), p. 534. 
ma impresora con muy pocos cambios. Lo que hace un Estado, otro Estado lo copia con pocos cambios y, así, se sigue un patrón similar. Si observamos el universo de los acuerdos comerciales regionales encontramos un fenómeno similar de copy-paste. ${ }^{110}$ En ambos casos, acuerdos de inversión y acuerdos regionales, la posición por defecto es la inclusión de un procedimiento de resolución de disputas ante un tercero, procedimiento que en el campo de la inversión incluye la toma de decisiones judiciales vinculantes entre inversionista y Estado, mientras que los acuerdos regionales involucran una opción algo más suave que la descrita. El préstamo sistémico del modelo de control judicial representa, sin duda, un tipo de impacto. Pero otra clase, "el impacto maduro", se refiere al préstamo de aspectos sustantivos de las decisiones de control constitucional de otros países.

Las interacciones horizontales también podrían moldear e informar la actitud de los tribunales nacionales hacia las normas internacionales como base para el control constitucional. El marco que propone Anthea Roberts para estudiar el derecho internacional comparado aborda la pluralidad de actitudes nacionales hacia la interpretación del derecho internacional y las formas en las que esta misma pluralidad facilita un diálogo rico sobre el contenido y el significado de las normas internacionales. ${ }^{111}$ Este diálogo legitima el ejercicio del control constitucional con base en dichas normas en cada una de las jurisdicciones en las que se aplica y sirve de ejemplo a otros sistemas en los que no se atreven a hacerlo. ${ }^{112}$

Existe otra explicación más profunda del impacto mutuo de los tribunales en diferentes jurisdicciones. Cuando un tribunal nacional incorpora a su jurisprudencia normas internacionales, corre el riesgo de poner a su propio país en desventaja frente a otras jurisdicciones en las que no se produce una incorporación similar. Por tanto, mientras más tribunales den el salto, más fácil será que otros sigan su ejemplo. Esto es particularmente cierto en relación con las normas económicas (a diferencia de las normas de derechos humanos) donde la regla internacional impacta directamente las relaciones entre los Estados.

También existe una relación vertical entre la segunda y la primera olas según la cual, el uso de normas internacionales puede abrir el camino para el control constitucional clásico impulsado por el Estado y viceversa. ${ }^{113}$ El Reino Unido aceptó por primera vez una forma bastante sólida de control constitucional en el contexto de la UE y esto, por lo menos, indirectamente allanó el camino

110 World Trade Organization, Regional trade agreements, en https://www.wto.org/english/tratop_e/region_e/ region_e.htm

111 A. Roberts, “Comparative international law? The role of national courts in creating and enforcing international law", International \& Comparative Law Quarterly 60 (1) (2011), pp. 73-74.

112 Benvenisti, "Reclaiming democracy: the strategic uses of foreign and international law by national courts", op. cit.

113 Para una discusión del contexto latinoamericano, véase AJIL Unbound, Symposium on the Constitutionalization of International Law in Latin America, 2015, http://www.iconnectblog.com/2015/11/symposium-on-theconstitutionalization-of-international-law-in-latin-america. 
para la eventual introducción de leyes sobre Bill of Rights. ${ }^{114}$ Historias similares pueden relacionarse de una forma $u$ otra con respecto a muchos tribunales $y$ jurisdicciones en la Unión Europea, en donde fue la disciplina y la costumbre de aplicar el derecho superior de la UE lo que se convirtió en un hábito que dio la bienvenida al control constitucional. ${ }^{115}$ En Italia -un país que estaba acostumbrado a un control constitucional que se encuentra en su propia Carta, pero menos amigable con una forma robusta de aplicar las normas internacionalesel movimiento ha ido en la otra dirección. Andre Nollkaemper ofrece una descripción elegante y elocuente del proceso: "La imagen que surge es una en la que el derecho internacional, por un lado, llega cada vez más a los tribunales nacionales y, por otro, muchos Estados y sus tribunales se esfuerzan cada vez más para permitir que el derecho internacional guíe sus prácticas judiciales". ${ }^{116}$

Podríamos argumentar que la tesis de Nollkaemper se aplica no solo al contenido del control constitucional, sino a su propia existencia como una institución estatal robusta.

\section{Prospectiva}

Esta historia de un "progreso" implacable en la difusión del control de constitucionalidad y la expansión de lo "constitucional" para abarcar incluso el derecho internacional, no ha estado libre de desafíos y críticas. Y estos desafíos y críticas dejan ver el surgimiento de lo que vemos como una tercera ola en la marea del control constitucional en el mundo contemporáneo.

\section{La crítica contramayoritaria}

Como es bien sabido, el control constitucional a nivel estatal vino con los desafíos frecuentes propios de las décadas de los sesenta y setenta en una variedad de jurisdicciones y que cuestionaban la legitimidad misma del control consti-

114 Un desarrollo importante para la ratificación de la Convención Europea que comenzó solo una década después de que la Convención entrara en vigor (fue firmada el 4 de noviembre de 1950), pues la CETS No. 5 entró en vigor el 3 de septiembre de 1953. Para discusión al respecto, S. Sterett, "Judicial review in Britain", Comparative Political Studies 26 (4) (1994), pp. 428-429. En 1998, casi 50 años después, el British Human Rights Act of 1998 fue aprobado, trayendo la Convención al derecho nacional británico. La ley le permitió a los individuos y a las organizaciones pedirles directamente a los tribunales nacionales británicos, y no solo al Tribunal Europeo, la aplicación de la Convención. Véanse J. Beatson, S. Grosz, T. Hickman, S. Palmer y R. Singh, Human Rights: Judicial Protection in the United Kingdom, London, Sweet \& Maxwell, 2008; R. Clayton y H. Tomlinson, The Law of Human Rights, 2 ed., New York, Oxford University Press, 2009; B. Dickson, Human Rights in the UK Supreme Court, Oxford, Oxford University Press, 2013.

115 También en los Países Bajos, la introducción del control constitucional fue traída al sistema nacional después de la ratificación de la Convención. G. van der Schyff y M. Adams, "Constitutional review by the judiciary in the Netherlands: A bridge too far?", German Law Journal 11 (2) (2010), pp. 400-401. Para mayor discusión sobre la influencia de la Unión Europea y el Tribunal Europeo de Derechos Humanos en el control constitucional nacional, véanse A. Stone Sweet y T. L. Brunell, "Trustee courts and the judicialization of international regimes: The politics of majoritarian activism in the European convention on human rights, the European Union, and the world trade organization", Journal of Law and Courts 1 (1) (2013), pp. 61-88; A. S. Sweet, "A cosmopolitan legal order: Constitutional pluralism and rights adjudication in Europe", Global Constitutionalism1 (1) (2012), pp. 53-90.

Zurn et al., Rule of law dynamics: in an era of international and transnational governance, op. cit., p. 8. 
tucional de la legislación como parte del llamado dilema contramayoritario. ${ }^{117}$ Aquí no deseamos ensayar las líneas de cada uno de los libretos de este debate. Creemos que este dilema planteó y sigue planteando cuestiones importantes para la democracia. Nos contentamos con decir simplemente que, de manera empírica, el control constitucional se ha adoptado en varias jurisdicciones a pesar de tales críticas y, en ocasiones, ha sido sometido a una variedad de técnicas (como varios mecanismos de anulación parlamentaria) para mejorar su legitimidad (esto sin perjuicio de erupciones o resistencias esporádicas).

\section{La cultura del individualismo - El déficit republicano}

El control constitucional está íntimamente relacionado con la protección de los derechos y constituye, en sí mismo, una cultura de derechos jurídicamente protegidos (sean estos fundamentales o de otro tipo), cultura que va en contravía de las nociones de deberes y responsabilidades individuales. En el discurso normal de los derechos, el "yo", el sujeto, es el portador de estos. En la teoría, esto por supuesto es cierto. Pero esta teoría no corresponde con la realidad de cómo realmente experimentamos el discurso de los derechos en acción. Esa realidad es "triangular" porque involucra a quien viola el derecho (típicamente una autoridad pública), la víctima de la violación del derecho que, cuando se trata de derechos humanos fundamentales (a diferencia, digamos, de los derechos del consumidor), es alguien por fuera del Estado, y el "yo" o el "nosotros", que normalmente somos observadores, leyendo sobre ello en la prensa o en otros medios.

Frente a esa realidad, es fácil observar que la cultura de los derechos humanos exige muy poco de sus principales sujetos/objetos. De hecho, en su mayor parte exige poco más que profesar una creencia en ellos. Para esta fe, uno ni siquiera tiene que ir a la iglesia una vez a la semana. La responsabilidad de su violación no suele ser de las personas, sino de la autoridad pública y la responsabilidad de abordar dicha violación recae en otras autoridades públicas, como los tribunales. Nuestro papel es típicamente suspirar con desaprobación mientras leemos sobre ello durante el desayuno. Lo que es fundamentalmente social se convierte en una virtud privada bastante barata. Y, de hecho, no se puede hacer mucho más que protestar a diferentes niveles de intensidad. En efecto, es cierto que la violación de los derechos humanos ocurre, mayorita-

117 A. M. Bickel, The Least Dangerous Branch, New Haven, Yale University Press, 1986, pp. 16-17. Véase también, R. A. Dahl, "Decision-making in a democracy: The Supreme Court as a national policy-maker", en Emory Law Journal 50 (2) (2001); M. A. Graber, "The nonmajoritarian difficulty: Legislative deference to the judiciary", en Studies in American political development 7 (1) (1993); M. J. Klarman, "Rethinking the Civil Rights and Civil Liberties Revolutions", en Virginia Law Review 82 (1) (1996); L. D. Kramer, The People Themselves: Popular Constitutionalism and Judicial Review, Oxford, Oxford University Press, 2005; M. Tushnet, Taking the Constitution away from the Courts, Princeton, Princeton University Press, 2000; J. Waldron, "The core case against judicial review", en The Yale Law Review 115 (6) (2006); K. E. Whittington, “'Interpose your friendly hand': Political supports for the exercise of judicial review by the United States Supreme Court", en American Political Science Review 99 (4) (2005). 
riamente, por cuenta de las autoridades públicas. La cuestión es que hay algo significativo en el hecho de que el valor tan alto que se da a la santidad de los derechos humanos fundamentales en el pensamiento liberal, sea precisamente lo que estructura la responsabilidad de los poderes públicos y lo que, a su vez, exija tan poco de los que, de buena fe, profesan su creencia en los derechos. La forma en que los derechos humanos se manifiestan en la matriz más amplia de la cultura política se asemeja a la crítica que se ofrece en relación con la solidaridad: es necesaria para hablar de agencia, pero esta última en sí misma no conduce a las virtudes y sensibilidades necesarias para la comunidad y la solidaridad reales.

En segundo lugar, en el paso de la virtud más social a la privada, con frecuencia el vocabulario de los derechos humanos se pierde en la traducción. La inviolabilidad de la dignidad humana se convierte en la inviolabilidad del yo, del ego. Como reveló el análisis sistemático de Ran Hirschl sobre la jurisprudencia de derechos constitucionales de Canadá, Israel y Nueva Zelanda, existe una clara tendencia común en la jurisprudencia constitucional a "adoptar una concepción estrecha de los derechos, enfatizando el individualismo lockeano y los aspectos diádicos y antiestatales de los derechos constitucionales". ${ }^{118}$

La cultura de los derechos, se quiera o no, socava un poco la contracultura de la responsabilidad y el deber. Subestimamos enormemente el lenguaje de la responsabilidad y el deber a nivel individual en comparación con el lenguaje de los derechos y las libertades. El individuo tiene derechos; la sociedad y las autoridades públicas tienen deberes y responsabilidades. Es fácil ver cómo no solo la prosperidad del mercado, sino su propio conjunto interno de valores y ethos de competencia y eficiencia material, junto con la cultura de los derechos, contribuyen a esa matriz de materialismo personal, egocentrismo, hastío al estilo Sartre y narcisismo en una sociedad que valora genuina y loablemente la libertad y los derechos humanos. Robin West definió este problema como alienación: "[Los derechos] nos alejan del temido otro del que dicen protegernos, de nuestras comunidades y del reconocimiento de incluso la posibilidad de una conexión humana no mediada". ${ }^{119}$

Finalmente, esta cultura de derechos es ajena y, en ocasiones, incluso hostil a los apegos que tienen las personas y la importancia que dan a su contexto nacional, especificidad cultural y cohesión social.

El elemento "republicano" también es bastante evidente en esta ecuación y se basa en dos consideraciones principales. Primero, la disciplina de la democracia mayoritaria requiere un demos, cualquiera que sea su definición, para

118 Hirschl, "The strategic foundations of constitutions", op. cit., pp. 162-163.

119 R. L. West, "Tragic rights: The rights critique in the age of Obama”, en William \& Mary Review 53 (2011), pp. $720-721$. 
que la minoría acepte la legitimidad de la toma de decisiones mayoritaria. Una mayoría que coacciona a una minoría fuera del marco de un demos se percibe como dominación extranjera. El demos en democracia no es léxico, es ontológico. En segundo lugar, el buen funcionamiento de una democracia, a través de elecciones, servicio público y similares, depende tanto del sentido de propiedad de sus ciudadanos, como de un mínimo de responsabilidad personal y compromiso con el bienestar del sistema de gobierno. Un sistema de gobierno en el que todo el mundo simplemente paga sus impuestos y no infringe la ley no es, ni podría ser, una democracia funcional en el sentido republicano. Así, en la medida en que una cultura de individualismo y atomización destruye la socialidad receptiva y responsable, socava también los cimientos de la democracia misma.

Si hay algún mérito en este análisis, sería que este explicaría cómo la cultura del control constitucional (tan íntimamente ligada a la cultura de los derechos) se convierte en parte esencial -y en ocasiones en el blanco- de un discurso contemporáneo que lamenta la ruptura del comunitarismo, de la responsabilidad colectiva y de la solidaridad humana, discurso que se ha vuelto más resonante y prominente, especialmente en tiempos de crisis económica y otras crecientes divisiones sociales y nacionales.

\section{El aplanamiento de la identidad}

Aquí usamos "identidad" en un sentido amplio para describir una sensibilidad judicial que está preocupada por garantizar al mismo tiempo 1) el respeto de los derechos fundamentales y otras normas constitucionales similares o los hábitos y las prácticas básicos de una gobernanza democrática representativa y responsable, y 2) otros aspectos "identitarios" adicionales del sistema de gobierno, para los cuales la teoría típicamente liberal sobre las normas propias del control constitucional ha sido mucho menos sensible. Hay varias facetas de esta sensibilidad. Nuestro análisis de la interacción horizontal y vertical (fertilización cruzada) entre la segunda y la tercera ola apunta a otra característica a la que hasta ahora no hemos prestado mayor atención. El resultado de esta fertilización cruzada es la creación de un activo de valor común global, tanto extranacional como transnacional. A menudo tomamos ese núcleo global común de valores bajo el concepto de patriotismo constitucional. El panorama general es, o parece ser (y aquí las apariencias tienen un peso social y político considerable), que el patriotismo constitucional -es decir, considerar ese activo normativo como fuente de lealtad y compromiso-, al mismo tiempo disminuye el sentido de especificidad política y cultural. Si es ese activo el que debe ser el punto focal de mi amor y lealtad a la patria, ¿por qué y cómo sería diferente mi amor por mi patria frente a mi amor por cualquier otra patria? El patriotismo en cuestión es noble, indispensable y una marca de nuestra civilización, pero deja amplias e importantes franjas empobrecidas de socialidad. 
Si tuviéramos que, con cierta crudeza, reducir (de nuevo) el núcleo normativo sustantivo de la revolución constitucional a sus elementos más esenciales, el resultado sería, como argumenta convincentemente Menachem Mautner, la protección de la libertad y la dignidad individuales, así como la promoción de la autonomía y la igualdad individuales. ${ }^{120}$ La dimensión internacional de los mismos también está fuertemente comprometida en la defensa contra los excesos del nacionalismo. Nadie puede protestar contra estas nobles aspiraciones y valores, pero la ausencia de lo social y colectivo es evidente. La primera y la segunda ola contribuyen, así, a la homogeneización cultural entre sociedades.

¿Por qué esta discusión es relevante? Desde una perspectiva normativa, el concepto de dignidad humana tiene dos facetas: una de ellas es la igualdad irreductible de los individuos, donde ninguno tiene más valor intrínseco que otro. Pero la segunda faceta es la singularidad de cada individuo donde ninguno es fungible con otro. Negar la singularidad de un individuo es un asalto tan grande a su dignidad como lo es la devaluación de su valor. Y lo mismo es cierto para las formas colectivas de socialidad, como las comunidades nacionales. Desde una perspectiva psicológica, el anhelo intrínseco de los individuos por dar sentido a su propia existencia a menudo encuentra su expresión en su pertenencia a una colectividad -una nación, por ejemplo- que tiene una historia única, una identidad cultural única y, sí, un destino propio.

Si combinamos lo normativo y lo psicológico, encontramos la raíz de la fuerza de las consideraciones identitarias, individuales y colectivas, que ejercen presión sobre la condición humana, para bien y para mal. Así que aquí también es evidente que en la medida en que 1) el fenómeno del control constitucional, tan omnipresente, implica un vínculo inextricable entre la manifestación de la primera y la segunda ola; y 2) como se acaba de argumentar más arriba, como resultado del hecho de que el acervo común de los valores se convierte en algo universal en lugar de nacional, este contribuye (o al menos se percibe que contribuye) a un "ataque" frontal a la identidad nacional o de grupo. Por lo tanto, no es de extrañar que el control constitucional se convierta en parte, e incluso en el blanco, de un discurso político que ha puesto en primer plano la "identidad" y ante el que, como veremos, los tribunales han reaccionado.

\section{Preocupaciones distributivas marginalizadas}

Las primeras críticas de los derechos humanos, sobre todo los estudios feministas y los estudios raciales críticos, censuraban la potencial subordinación que los derechos podrían generar. ${ }^{121}$ Exponían las formas en que la protección de

120 M. Mautner, Law and the Culture of Israel, Oxford, Oxford University Press, 2011.

121 K. W. Crenshaw, "Race, reform, and retrenchment: Transformation and legitimation in antidiscrimination law", en Harvard Law Review 101 (1987); R. Delgado, "The ethereal scholar: Does critical legal studies have what minorities want", en Harvard Civil Rights-Civil Liberties Law Review 22 (1987); F. Olsen, "Statutory rape: 
la libertad o la autonomía de los individuos contra la intervención del Estado podía facilitar una mayor subordinación y el ejercicio del poder por parte de los fuertes contra los débiles. Como señala Robin West, "aunque los derechos limitan las relaciones injustas en el ámbito privado, estos corren el riesgo de legitimar un mundo generalmente injusto en el que se enmarcan esos momentos particularizados de injusticia". ${ }^{122}$ Algunos comentaristas abordan críticamente la correlación entre la difusión del control constitucional de primera y segunda olas, y los procesos de privatización y la globalización de finales del siglo XX. Como señalan algunos, "precisamente porque la mayor ambición de la revolución de los derechos humanos es establecer un piso normativo y real de protección, no ha logrado responder, o por lo menos reconocer, la destrucción de la igualdad por parte del neoliberalismo". ${ }^{123}$ De manera similar, los académicos constitucionalistas latinoamericanos describen críticamente las ramificaciones redistributivas de los procesos de constitucionalización. Helena Alviar García, por ejemplo, critica la protección de los derechos de propiedad por parte de los regímenes constitucionales y concluye que

... en Colombia, la redistribución se ve frenada debido a la coexistencia de diferentes definiciones de propiedad; la concentración de recursos públicos para planes de desarrollo económico que privilegian una visión clásica liberal del crecimiento, la propiedad y la distribución, así como los conflictos existentes para el acceso a la tierra. En el caso de Bolivia, la redistribución se ve frenada por la dependencia de la trayectoria de las políticas neoliberales junto con las contradicciones entre la necesidad de un título individual y la definición más socialista de propiedad. ${ }^{124}$

De manera similar, Javier Couso describió que, a pesar de su gran celo, los tribunales constitucionales de América Latina no pueden lograr la transformación social y económica. ${ }^{125}$ Los procesos constitucionales en Europa del Este y Central se orientaron de forma similar hacia los derechos privados y la liberalización del mercado.

Las preocupaciones sobre las consecuencias redistributivas de los procesos de constitucionalización de la segunda ola desvían nuestra atención hacia las desigualdades globales entre el Norte y el Sur y, a menudo, se expresan en términos imperialistas. ${ }^{126}$ Las críticas de los TWAIL (Third World Approaches to

A feminist critique of rights analysis", en Texas Law Review 63 (1984); P. J. Williams, Alchemy of Race and Rights: Diary of a Law Professor, Cambridge, Harvard University Press, 1992.

122 West, "Tragic rights: The rights critique in the age of Obama", op. cit., pp. 720-721. Véase también, P. Gabel, "Phenomenology of rights-consciousness and the pact of the withdrawn selves", en Texas Law Review 62 (1983), p. 1569.

123 Moyn, "A powerless companion: Human rights in the age of neoliberalism", Law and Contemporary Problems 77 (2014), p. 149.

124 H. Alviar Garcia, "Looking beyond the constitution: The social and ecological function of property", en Comparative Constitutional Law in Latin America, Cheltenham, Edward Elgar Publishing, 2017.

125 J. Couso, "The "economic constitutions" of Latin America: between free markets and socioeconomic rights", en Comparative Constitutional Law in Latin America, Cheltenham, Edward Elgar Publishing, 2017.

126 La crítica de David Kennedy a los derechos humanos reúne las preocupaciones identitarias con efectos redistributivos globales: "Me preocupa que el movimiento internacional de derechos humanos pueda ocupar el campo, desplazando otras formas de perseguir la justicia social y otros vocabularios emancipadores que a ve- 
International Law, Enfoques del derecho internacional del tercer mundo) enfatizan cómo la construcción eurocéntrica del movimiento de derechos humanos no desafía, e incluso profundiza, la desigualdad global. Como señaló Mutua,

... un proyecto político así, no solo continúa descaradamente con las heridas históricas, sino que no llega a un acuerdo con las emergentes [...] el corpus de los derechos humanos simplemente es incapaz de confrontar estructuralmente y de una manera significativa los profundos desequilibrios de poder y privilegios que afligen a nuestro mundo. ${ }^{127}$

La capacidad limitada de los sistemas jurídicos para abordar las preocupaciones distributivas pasó a un primer plano como resultado de la crisis económica de 2008 y la crisis de la deuda europea. ${ }^{128}$

La desigualdad y la justicia distributiva no han sido, en general, elementos fundamentales para las instituciones de gobernanza global. Benedict Kingsbury comentó proféticamente hacia fines de la década de los noventa, que el surgimiento de los regímenes de gobernanza global requeriría tomar en cuenta la desigualdad mucho más en serio, aunque hasta ahora no se ha hecho:

... la política pública global emergente animada por sus compromisos con los mercados, la sociedad civil, la paz liberal, el Estado de Derecho, la comunicación sin trabas y el transnacionalismo [...] considera modestamente la igualdad como un estilo de política y como componente procesal de la democracia y el Estado de Derecho, pero no está claramente comprometida con la reducción sustancial de la desigualdad global [...] si la soberanía fuera desplazada como concepto normativo fundamental para la estructura del derecho internacional, un medio alternativo para gestionar la desigualdad se volvería esencial. Actualmente no se ofrece ninguna alternativa de este tipo. ${ }^{129}$

\section{El déficit democrático: gobernanza sin gobierno}

Los desarrollos conseguidos por la primera ola facilitaron la comprensión según la cual, formas más o menos robustas de control de constitucionalidad resultaban necesarias para la existencia de una comunidad política democrática.

ces pueden ser más efectivos, como vocabularios religiosos, tradiciones locales y herramientas enfocadas más directamente en la justicia económica o la solidaridad social. Hay muchas formas de buscar la justicia social. Los derechos humanos son solo una, y no siempre la más apropiada. Me preocupa, además, que los derechos humanos, dados sus orígenes, sus portavoces, sus preocupaciones, hayan sido a menudo un vocabulario del centro contra la periferia. Un vehículo para el imperio en lugar de un antídoto para el imperio". D. Kennedy y D. Mayhew, The Dark Sides of Virtue: Reassessing International Humanitarianism, Princeton, Princeton University Press, 2004, p. 133.

127 M. Mutua, Human rights: A political and cultural critique, Philadelphia, University of Pennsylvania Press, 2002, p. 77. Para un análisis de las críticas al derecho internacional de los derechos humanos B. Golder, “Beyond redemption? Problematising the critique of human rights in contemporary international legal thought", en London Review of International Law 2 (1) (2014).

128 Véase, por ejemplo, F. W. Scharpf, "Monetary union, fiscal crisis and the disabling of democratic accountability", en Politics in the Age of Austerity, Cambridge, Polity Press, 2013.

129 B. Kingsbury, "Sovereignty and inequality", en European Journal of International Law 9 (4) (1998), p. 600. 
El control judicial, que alguna vez fue la excepción, se había convertido en la norma por defecto y su incorporación supuso una profunda transformación ontológica del significado de una democracia como una democracia constitucional. La interacción entre la democracia y la segunda ola es, a la vez, más delicada e interesante. La internacionalización de las normas constitucionales que evolucionaron como parte de la segunda ola fue, en gran medida y a nuestro juicio, provocada por el mismo ímpetu liberal y democrático. La importancia del reposicionamiento del individuo mucho más al centro de la vida pública -como parte y componente de la misma definición de un Estado liberal democrático- y la constatación de la desigualdad del poder entre el individuo y la autoridad pública, no solo justificaron, sino que también llevaron a que los Estados tuvieran la disposición de hacerse cargo, ellos mismos, de los compromisos "constitucionales" internacionales que se derivan de estos ámbitos.

No obstante, el proceso de gobernanza internacional ya descrito genera una nueva versión de la dificultad contramayoritaria. La segunda ola del control de constitucionalidad, o bien es desarrollada por jueces internacionales o se funda en normas internacionales que derivan su autoridad de mecanismos de gobernanza que carecen de un gobierno realmente responsable y de la presencia activa de los gobernados (esto es, de la comunidad política). A nivel internacional, no existen las ramas del poder o las instituciones públicas a las que estamos acostumbrados desde una perspectiva estatal. Lo anterior puede ser algo trillado, pero es crucial. Cuando existe gobernanza, esta debería ser democráticamente legítima. La democracia supone un demos y la existencia del poder público. Cualquier modelo democrático que se pretenda adoptar deberá poseer los elementos de responsabilidad pública, representación y alguna medida de deliberación. Y existe la suposición de que todas las nociones de representación, responsabilidad pública y deliberación pueden injertarse o trasplantarse en las instituciones clásicas del poder público. Igualmente, frente a cualquier justificación que pueda dársele a la disciplina democrática de la regla de la mayoría, siempre se asume que la mayoría y la minoría están situadas al interior de una comunidad política cuya definición es compartida por la mayoría de sus súbditos. En contraste, la forma de gobernanza internacional, sin poder público y sin demos, no tiene ningún asidero o ninguna base por medio de la cual podamos injertar, en la arena internacional, nuestras nociones estatales de democracia.

Además, la posición alternativa que señala que esta legitimidad puede adquirirse a nivel estatal mediante el control democrático de la política internacional, pierde su poder persuasivo en este contexto incluso más que en relación con los valores macro de la comunidad internacional. La micro y mesorregulación internacional es difícilmente un asunto de control democrático por parte de las instituciones estatales. La presa que se buscaba cazar o contener en el modelo tradicional era la rama ejecutiva: el gobierno estatal. En el universo de la regulación transnacional ni siquiera los ejecutivos tienen el control. 
Las teorías democráticas también hacen cortocircuito -sean ellas liberales o neoliberales, consociativistas o incluso modelos élite-schumpeteristas- cuando tratan de aplicarse a estas formas de gobernanza global. ¿Quién es el principal y quién es el agente? ¿Quiénes son las partes interesadas? Podemos definir demos y demoi de diferentes maneras. Pero no existe ninguna teoría de la democracia que sea convincente sin demos. El demos es un requisito ontológico de la democracia. Y no existe ningún demos subyacente a la gobernanza internacional. Aún más: no es sencillo conceptualizar cómo luciría ese demos en ese ámbito internacional. La teoría de redes y el constructivismo son útiles para describir la forma que toma la gobernanza internacional y para explicar cómo funciona. A pesar de esto, estas descripciones y explicaciones, en lugar de resolver los problemas de legitimidad, los profundizan.

El problema de la "democracia" para el derecho internacional no es más si existe o no un derecho a la democracia (derecho que, por ejemplo, justificaría la negativa a un reconocimiento internacional o incluso la intervención para restaurar la democracia luego de su supresión por medio de un golpe de Estado). En lugar de ello, y de cara a una comunidad internacional que se "apropia" y define valores materiales y espirituales, así como funciones administrativas del Estado, el problema es cómo podemos establecer mecanismos que, en el vocabulario de la teoría política normativa, puedan legitimar este tipo de gobernanza. Si no se encuentra una respuesta a este interrogante, las inmensas ganancias obtenidas gracias a la evolución sistemática de la producción legislativa y de la exigibilidad del derecho, serán normativa e incluso políticamente anuladas.

La delegación de la toma de decisiones y de autoridad en las instituciones globales origina otras preocupaciones como la reducción del espacio público para la deliberación y el correlativo fortalecimiento de negociaciones informales y de los procesos de toma de decisión regulatoria por expertos. La globalización y la fragmentación podrían socavar aún más los pesos y contrapesos al interior de las democracias. Hay una tendencia en cabeza de Estados fuertes hacia el uso cada vez más frecuente de canales informales o de mecanismos de derecho blando con el propósito de promover sus políticas por fuera del ojo vigilante del escrutinio público, políticas que no se presentan ni discuten por los congresos o parlamentos nacionales. ${ }^{130}$

Los déficits de la democracia se extienden a asuntos de Estado de derecho. En la medida en que el derecho internacional no tenga legitimidad democrática, el arrastre o la fuerza hacia el cumplimiento de las decisiones proferidas por instituciones internacionales se debilitará empírica y normativamente. Además, muchos órganos internacionales que adjudican controversias, incluida

130 E. Benvenisti y G. W. Downs, "The empire's new clothes: Political economy and the fragmentation of international law", en Stanford Law Review 60 (2007); Benvenisti y Downs, Between Fragmentation and Democracy: The Role of National and International Courts, op. cit., cap. 5. 
la Corte Internacional de Justicia (CIJ), actúan como cortes de primera y última instancia. Su decisión es final y no tiene apelación (por oposición a una norma común de justicia que establecería que las decisiones judiciales deben ser apelables).

Una vez más: si hay algún mérito en este análisis, es fácil ver cómo este alimenta y provee un discurso social y político consistente en "retomar el control" y que es muy potente en una multiplicidad de manifestaciones de la política contemporánea.

\section{La tercera ola: reacción, movimiento dialéctico o arrebatamiento radical}

Aunque sus contornos son aún borrosos, creemos que los retos anteriores son elementos importantes que allanan el terreno para una serie de desarrollos que definimos como la tercera ola. En otras palabras, la tercera ola es, entre otros, una respuesta y una reacción a los retos que se derivan de la primera y segunda olas. Es cierto que existe alguna imprecisión cuando en este escrito caracterizamos la evidencia empírica disponible como una verdadera ola. Es tal vez más un oleaje de menor intensidad. Y estamos al tanto de los profundos acontecimientos políticos que informan y moldean los procesos que exploramos bajo la tercera ola como el Brexit, Trump, Marine Le Pen, etc. Sin embargo, nuestro centro de atención no es la exploración de estos acontecimientos de manera directa, sino, simplemente, el estudio de las formas en que estos sucesos se encausan y mitigan mediante procesos judiciales y el control de constitucionalidad (o las formas en las que los jueces rechazan por completo su conocimiento en sede judicial).

El movimiento que emprendemos ahora tiene una doble naturaleza. En un primer momento, queremos presentar una muestra de casos que, en nuestro concepto, ilustra algunas líneas de jurisprudencia constitucional doméstica que pueden entenderse como reacciones a los retos producidos por las dos primeras olas y que ya se explicaron. En concreto, hemos elegido casos que ilustran, primero, una sensibilidad a los déficits democráticos y de estado de derecho que existen en la gobernanza internacional y transnacional. Y, segundo, seleccionamos casos que reflejan una sensibilidad al dilema identitario. Como se anotó, desde una perspectiva empírica es aún muy temprano para hablar de una verdadera "ola". De cualquier forma, no creemos que estos casos sean simplemente atípicos sino, más bien, presagian una nueva sensibilidad.

Este movimiento, como sucedió atrás, no es solo cartográfico. Queremos ofrecer los "contornos reactivos" de la tercera ola como un dispositivo de enmarcamiento y como una hipótesis: como un prisma o lente para entender casos de derecho constitucional de alrededor del mundo que, con el paso del tiempo y el 
trabajo de académicos mucho mejor ubicados para identificar y analizar estos casos, nos permita verificar si el oleaje, en efecto, se está convirtiendo o se ha convertido en una verdadera ola o si, por el contrario, este se ha apaciguado.

Lo que está en juego, desde una perspectiva normativa, es importante y complejo. Por una parte, los retos que hemos articulado son reales y, por esta razón, deberíamos darle la bienvenida a aquellas intervenciones judiciales nacionales que procuren corregir los déficits de la democracia, de la desigualdad económica y de la identidad/solidaridad que se avizoran en el horizonte. Este tipo de intervención podría, de esta forma, concebirse como una manera de empoderar voces importantes que se han debilitado o silenciado en el discurso del control de constitucionalidad de los tribunales nacionales y transnacionales. La virtud de resolver los déficits democráticos o del Estado de derecho es obvia. Pero incluso "identidad" no es una palabra sucia si se le ve como una característica social que encuentra correspondencia con anhelos positivos dignitarios de la condición humana, así como con características sociales igualmente positivas de responsabilidad individual y solidaridad colectiva. Tener una voz o expresarse también debería entenderse como algo dialógico: no como simple resistencia o rechazo a través de la confrontación o la corrección. De este modo, y como veremos, en el famoso caso Kadi, por ejemplo, la CEJ parece por lo menos abrir la puerta para retirar su intervención una vez el sistema internacional instituya su propio mecanismo de control judicial de las Resoluciones del Consejo de Seguridad que afecten directamente a los individuos. Algunos movimientos dialógicos similares pueden verse también en algunos casos del Reino Unido y otros.

Por otro lado, tener una voz o expresarse puede desembocar en un escape: escape de los beneficios del multilateralismo, de la gobernanza transnacional -que son esenciales para enfrentar problemas que no son proclives a ser resueltos por cuenta de soluciones nacionales-, de un compromiso verdadero hacia los derechos humanos individuales con el pretexto de los bienes colectivos, de las preocupaciones identitarias legítimas y del patriotismo como una disciplina de amor y solidaridad que se contrapone a un espíritu y ethos de xenofobia y atavismo. Las cortes, en nombre de la democracia, el Estado de derecho y la identidad constitucional, pueden hacer parte de este discurso de escape destructivo. Como se anotó más arriba, en este escrito nos interesa menos, en este contexto, analizar un verdadero "escape à la Brexit" (aunque vale decir que dichos movimientos y tendencias, indudablemente, tienen un impacto en la forma en la cual deciden las cortes y los jueces pueden actuar como frenos o catalizadores de estos). La opción del escape que fundamentalmente nos preocupa es aquella en la cual las cortes nacionales desafían la normatividad transnacional con razones discrepantes y con vehemencia. Como veremos, incluso en este tipo de situaciones puede haber casos -el equivalente a la desobediencia civil-en los que una decisión de escape puede no ser condenable por completo desde una perspectiva normativa. 


\section{La regla de manifestación de la tercera ola}

Una dimensión de la tercera ola es entenderla como una reacción judicial a dos fenómenos interconectados que ya se describieron: primero, a la pretensión de que el derecho internacional representa una norma jurídica superior al interior de la jurisdicción nacional mientras, simultáneamente, se jacta de sus extremadamente débiles credenciales democráticas. Este problema es tan antiguo como el mismo derecho internacional. Pero se ha vuelto más agudo como resultado de la segunda ola del control de constitucionalidad aunada al crecimiento exponencial de normas de derecho internacional y transnacional que reclaman ese estatus normativo superior. Segundo, si el control judicial tiene como parte de su esencia y razón de ser la reivindicación de un control sobre los legisladores en nombre de una norma superior, ¿cuál es esa norma superior de derecho internacional y quién será el encargado de hacerla exigible?

Este problema y la necesidad de tener una "Norma Superior (superior)" (es decir, por encima del propio derecho internacional) fueron reconocidos por el derecho internacional con la introducción (con mucha fanfarria) en la década de los sesenta, del concepto de ius cogens. Pero el contenido del ius cogens es tan minimalista, que difícilmente podría suministrar un contenido sustantivo lo suficientemente denso para lograr un control judicial efectivo de las normas de derecho internacional, de manera general, y de las normas de derecho administrativo global, más específicamente. Por esa razón, si queremos que este vacío en el Estado de derecho pueda llenarse, el reto que debemos enfrentar no puede ser simplemente el de encontrar arreglos institucionales adecuados -como la existencia de cortes y tribunales que, fundamentalmente, puedan llevar a cabo esta tarea-, sino desarrollar un contenido normativo que, como mínimo, responda a las expectativas del control judicial en el nivel doméstico. Después de todo, si aquello que tradicionalmente era regulado por la legislación nacional o el derecho administrativo ahora ha migrado a la esfera internacional, ¿por qué esta migración o transición hacia lo internacional debería ir acompañada de una disminución sustantiva de los criterios sustantivos que definen su constitucionalidad? Nota bene: esto no es, por tanto, el viejo fenómeno de unas cortes domésticas que se resisten a la autoridad y a la supremacía de las normas jurídicas internacionales. Se trata, mejor, de un retroceso del orden jurídico internacional en el cual la gobernanza internacional se somete a formas débiles de control de constitucionalidad y, por ello, cuando las cortes nacionales intervienen, pueden perfectamente emplear los recursos constitucionales a su alcance en su jurisdicción.

Como consecuencia de lo anterior, uno de los desarrollos más interesantes en y del constitucionalismo internacional en años recientes, ha sido el escrutinio adelantado por órganos judiciales de la conducta y de la hechura de las normas por parte de organizaciones internacionales, así como de regímenes internacionales propiamente dichos. El ejemplo más obvio, sistemático y consisten- 
te es, por supuesto, la Unión Europea. Esto es así, incluso si se considera la queja común de acuerdo con la cual esta Unión ejerce un control más estricto sobre el cumplimiento de las normas de la Unión por los Estados miembros, que aquel que desarrolla sobre las instituciones de la misma Unión Europea.

En otros foros internacionales este desarrollo es, hoy en día, un fenómeno caótico, descoordinado y espontáneo que ha sido liderado por dos agentes principales. La proliferación de tribunales internacionales creados en el marco de organizaciones y regímenes internacionales que se superponen ha significado que no rara vez la conducta, la hechura de normas e incluso las decisiones judiciales de una organización internacional son examinadas por los órganos judiciales que pertenecen a otra de ellas. Aún más interesante, complejo y retador es el escrutinio "constitucional" de la conducta y las normas de regímenes y organizaciones internacionales -incluida la propia ONU- por parte de cortes constitucionales y supremas de los Estados. Este asunto es realmente prometedor, pero también peligroso. Dada la escasez de un control judicial sistemático a nivel internacional, uno de los principales argumentos de este artículo es que, en este punto, las cortes nacionales una vez más jugarán un rol importante (no sin problemas) y, de hecho, ya han comenzado a desempeñar dicho rol. Es por esto que vamos a dedicar la mayor parte de nuestra atención al análisis de las cortes nacionales.

Lo que nos interesa por el momento no son los arreglos institucionales sino los criterios y el contenido normativo que debe aplicarse cuando las cortes nacionales asumen la tarea de garantizar la constitucionalidad de las normas internacionales. En efecto, bajo este sistema en constante evolución, es de esperar que las cortes cambien su "camiseta" o función. En un primer rol -el clásico de los jueces a nivel interno-, las cortes actúan como las guardianas de la constitución frente a los actos domésticos de gobernanza, sean estos de origen legislativo o administrativo. En un segundo rol, las cortes actúan como un tribunal híbrido doméstico/internacional asegurándose que el Estado cumpla con sus obligaciones jurídicas internacionales, especialmente cuando estas obligaciones tienen también una naturaleza constitucional como ocurre con la protección internacional y universal de los derechos humanos. Y tercero: ante la ausencia de una jurisdicción internacional apropiada, las cortes pueden ser llamadas a actuar en modo loco parentis con el propósito de garantizar la corrección constitucional de las normas internacionales (esta es una práctica que está recién comenzando). En estas situaciones, el juez nacional debe asegurarse de no aplicar estándares constitucionales nacionales, sino los estándares universales apropiados en el marco de la norma jurídica bajo examen.

El litigio del caso Kadi es el ejemplo más famoso de esta tercera ola de jurisprudencia y ejemplifica sus promesas y problemas. Este caso trajo a la luz, esta vez en términos institucionales globales, la clásica preocupación acerca de la tiranía de la mayoría y expuso de manera contundente el problema del 
irrespeto de los derechos por las mayorías en el ámbito internacional (discutido hasta ese momento especialmente en ámbitos académicos). ${ }^{131}$ Luego de los atentados del 9/11, el Consejo de Seguridad de la ONU profirió la Resolución 1267 y estableció un "Comité de Sanciones" que tenía la autoridad de incluir en una "lista negra" los nombres de aquellos individuos o entidades que, se consideraba, tenían vínculos con actividades terroristas. ${ }^{132} \mathrm{En}$ 2001, el Comité de Sanciones de la ONU añadió el nombre del señor Yasin Kadi a las listas de la ONU. La Unión Europea hizo lo mismo poco tiempo después por medio de los Reglamentos 2199/2001 y 2062/2001. Todos los bienes del señor Kadi fueron congelados a nivel mundial como resultado de su inclusión en la lista por parte del Consejo de Seguridad de la ONU, a pesar de que no se le informaron las razones de dicha decisión y no se le dio la oportunidad de discutirla. ${ }^{133} \mathrm{El}$ señor Kadi controvirtió esta medida ante las cortes europeas. En Kadi I, el Tribunal Europeo de Primera Instancia (TPI) consideró que en tanto las medidas del Consejo de Seguridad (así como las medidas comunitarias) no quebrantaron el ius cogens, estas constituían una interferencia justificada sobre los derechos fundamentales. ${ }^{134}$ La sentencia del TPI fue revocada por la CEJ (Kadi II). La CEJ sostuvo que los derechos de Kadi, en particular su derecho a ser oído, fueron transgredidos y anuló los reglamentos bajo análisis:

Pues bien, en lo que respecta al Sr. Kadi, el Reglamento controvertido fue adoptado sin ofrecerle garantía alguna de que se le permitiría exponer su caso a las autoridades competentes, y ello en unas circunstancias en las que la restricción de su derecho de propiedad debe calificarse de considerable, habida cuenta del alcance general y de la duración efectiva de las medidas restrictivas que le fueron impuestas. Procede concluir por tanto que, en las circunstancias del presente caso, la imposición al Sr. Kadi de las medidas restrictivas establecidas por el Reglamento controvertido como consecuencia de su inclusión en la lista recogida en el anexo I de dicho Reglamento constituye una restricción injustificada de su derecho de propiedad. Por lo tanto, procede considerar fundado el motivo en el que el Sr. Kadi invoca la violación de su derecho fundamental al respeto de su propiedad. Se deduce del conjunto de consideraciones expuestas que procede anular el Reglamento controvertido en lo que respecta a los recurrentes. ${ }^{135}$

131 A. Bogdandy, R. Wolfrum, J. Bernstorff, P. Dann y M. Goldmann, “The exercise of public authority by international institutions: advancing international institutional law", Springer Science \& Business Media 210 (2010).

132 Las resoluciones clave son United Nations, Res. 1267; S.C. Res. 1390, U.N. S.C.O.R., 57th Sess., 4452d Mtg; Res. 1333. La 1267 fue la que creó el Comité de Sanciones.

133 Las sentencias alrededor de Kadi incluyen decisiones del Tribunal Europeo de Primera Instancia, Kadi v. Council of the European Union, E.C.R. II-3659 - Court of First Instance, General Court -T-315/01, 2005 (Kadi I); la del Tribunal de Justicia de la Unión Europea, Kadi v. Council of the European Union, E.C.R. I-6351, EU:C:2008:461 - General Court of the European Union - C-402/05 P, C-415/05 P, 2008 (Kadi II); la del Tribunal General de la Unión Europea, Kadi v. European Commission, E.C.R. II-5177, EU:T:2010:418 - General Court - General Court, 2010 (Kadi III); y del Tribunal de Justicia de la Unión Europea, European Commission v. Kadi, EU:C:2013:518 - European Court of Justice - C-584/10 P, C-593/10 P, and C-595/10 P, 2013 (Kadi IV). Un panorama general del litigio alrededor de Kadi pude consultarse en G. De Búrca, "The European Court of Justice and the international legal order after Kadi", en Harv. Int'l LJ 51 (2010), pp. 1-2.

134 Kadi v. Council of the European Union, E.C.R. II-3659 - Court of First Instance, General Court -T-315/01, párr. 258.

135 Kadi v. Council of the European Union, E.C.R. I-6351, EU:C:2008:461 - General Court of the European Union - C-402/05 P, C-415/05 P, párrs. 369-372. 
Luego de esta sentencia, la Comisión Europea mantuvo la inclusión del señor Kadi en la lista, pero suministró un resumen de las razones que soportaban esta decisión. Como consecuencia de esto, el señor Kadi controvirtió, una vez más, esta nueva medida ante el Tribunal General de la Unión Europea en el caso Kadi III. La Corte reiteró los puntos centrales de Kadi II y fue enfática en señalar que un control jurisdiccional, "en principio completo", "no solo [recae] sobre la aparentemente correcta fundamentación del acto impugnado, sino también sobre los elementos de prueba y de información en los que se basan las apreciaciones realizadas en dicho acto". ${ }^{136}$ La CJE anotó, además, que el proceso de reexamen al interior del sistema de la ONU no puede dar lugar a una "inmunidad de jurisdicción generalizada" al interior del orden jurídico de la comunidad. Dado que el procedimiento vigente no garantiza efectivamente la protección judicial, "los tribunales comunitarios deben garantizar un control [...] completo". Varios autores consideraron que esta aproximación de la CJE evocaba la lógica detrás del fallo Solange II emitido por el Tribunal Constitucional alemán al restringir la intervención de los jueces comunitarios a aquellas situaciones en las que la decisión de la institución internacional respectiva no obtuviese una protección adecuada a la luz de los estándares europeos. Como ha observado Antonios Tzanakopoulos,

... la CEJ, de este modo, dejó abierta la puerta para una revisión de su propia posición en línea con lo dicho en Solange II: la CEJ parecería sugerir que cesará su intervención y deferirá al juicio de la ONU, en caso de que la ONU apruebe un procedimiento que ofrezca una protección judicial adecuada (no necesariamente equivalente). ${ }^{137}$

En Kadi IV el TJUE se abstuvo de revisar la decisión de la CEJ. En lugar de ello, afirmó que: "la inexistencia de inmunidad de jurisdicción en el caso de los actos de la Unión que aplican medidas restrictivas a nivel internacional" se fundamenta en el hecho de que las garantías constitucionales en la Unión Europea se fundan en el principio de Estado de derecho y, por esto, requieren la disponibilidad de un "control jurisdiccional de la legalidad de todo acto de la Unión [...] desde el punto de vista de los derechos fundamentales garantizados por la Unión". ${ }^{138}$

El litigio alrededor de Kadi revela los graves defectos en términos democráticos y de Estado de derecho de instituciones globales como el Consejo de Seguridad: si no es posible controvertir la violación de los derechos del señor Kadi en el contexto de una arquitectura jurídica que le ha otorgado supremacía al Consejo de Seguridad de acuerdo con el artículo 103 de la Carta de las Naciones Unidas, entonces los derechos al debido proceso y al control judicial estarán

136 Kadi v. European Commission, E.C.R. II-5177, EU:T:2010:418 - General Court - General Court, párr. 135.

137 A. Tzanakopoulos, "Judicial dialogue in multi-level governance: the impact of the Solange argument", en The practice of international and national courts and the (de-) fragmentation of international law, Oxford, Hart Publishing, 2009.

138 European Commission v. Kadi, EU:C:2013:518 - European Court of Justice - C-584/10 P, C-593/10 P, and C-595/10 P, párrs. 66-67. 
seriamente comprometidos. No obstante, la forma en la cual se deberían definir las relaciones entre los diferentes órdenes jurídicos para mitigar dichos defectos es una materia altamente debatida, y la decisión y el razonamiento de la Corte Europea no han sido recibidos universalmente con los brazos abiertos como lo han expresado agudamente de Búrca et al. ${ }^{139}$

Este fallo, sin embargo, tuvo implicaciones sistemáticas para el orden internacional considerado como un todo. Responder a las preguntas que se han formulado a lo largo de esta sección es algo central para la juridicidad y legitimidad de los regímenes de gobernanza globales. Como ha comentado Devika Hovell:

El litigio de Kadi fue un punto de inflexión. Al tener la capacidad de abrir un hoyo del tamaño de la Unión Europea en la red de sanciones, las cortes europeas obligaron al Consejo a considerar seriamente formas de repartición del poder de una manera en la que otras instituciones no lo habían conseguido. En términos prácticos, el caso de Kadi fue, sin duda, el factor más importante que persuadió al Consejo de Seguridad sobre la necesidad de adelantar una reforma procesal significativa y que llevó al establecimiento de la Oficina del Ombudsperson de la ONU. ${ }^{140}$

En efecto, mientras que los recurrentes le solicitaron a la CEJ que revisara las consecuencias del régimen de sanciones frente a su aplicación doméstica en Europa, esta Corte examinó de facto el régimen de sanciones del Consejo de Seguridad, lo cual desembocó en una serie de reformas considerables a dicho régimen con el fin de atender las críticas normativas de la Corte. Las fuentes de derecho que usaron los jueces europeos al ejercer el control judicial fueron europeas. Este uso refleja una aproximación más bien dualista que le confiere supremacía al derecho europeo sobre el internacional. ${ }^{141}$

Es posible ofrecer otra perspectiva adicional al litigio de Kadi si se adopta el punto de vista de nuestras tres olas. El rol de las cortes domésticas como guardianas de los derechos a través del ejercicio del control de constitucionalidad es la razón de ser de la primera ola. La supremacía de las normas internacionales es el corazón de los desarrollos de la segunda ola. Estas dos olas chocan entre sí -a la luz de los retos que cada una de ellas produce- en el contexto de la tercera ola y en aquellas situaciones en las que las instituciones jurídicas internacionales ejercen autoridad sin responsabilidad política. La jurisprudencia

139 Véanse, por ejemplo, A. von Bogdandy, “Guest editorial: Let's hunt zombies”, ESIL Newsletter; Búrca, "The European Court of Justice and the international legal order after Kadi", op. cit., p. 2; Fassbender, "The United Nations Charter as Constitution of the International Community", op. cit., p. 333; H. G. Krenzler y O. Landwehr, "'A New Legal Order of International Law': On the Relationship between Public International Law and European Union Law after Kadi", en From Bilateralism to Community Interest, Oxford, Oxford University Press, 2011, p. 1022; R. Pavoni, "Freedom to choose the legal means for implementing UN Security Council Resolutions and the ECJ Kadi Judgment: A misplaced argument hindering the enforcement of international law in the EC", Yearbook of European Law 28 (1) (2009).

290140 D. Hovell, "Kadi: King-Slayer or King-Maker? The shifting allocation of decision-making power between the UN Security Council and Courts", en The Modern Law Review 79 (1) (2016), p. 148.

141 Para una analogía con Medellín, véase J. H. H. Weiler, “Editorial”, en The European Journal of International Law 19 (5) (2008). 
de Kadi respaldó la lógica de Ely que se aplica a la primera ola del control de constitucionalidad: la protección de los derechos individuales frente el poder excesivo de las autoridades públicas. Pero es posible también que las cortes estén luchando en favor de un sistema democrático de pesos y contrapesos e, incluso, por ellas mismas. El espacio administrativo global y la creciente influencia de los regímenes regulatorios globales se originan en una delegación por parte de los ejecutivos nacionales hacia las instituciones internacionales con el propósito de eludir cualquier escrutinio.

A pesar de lo dicho, el fallo de la CEJ también tiene un lado oscuro. Esta sentencia privilegió los valores de la Unión Europea y consideró que estos valores representan el criterio correcto para adelantar el control judicial, en lugar de -tal vez más apropiadamente- suplir el déficit del Estado de derecho a nivel internacional por medio de la construcción de criterios que reflejaran la moralidad de la comunidad internacional en su integridad. Desde esta perspectiva, la aproximación del Tribunal de Primera Instancia puede considerarse más apropiada. En la práctica, el resultado final puede ser el mismo, pero la decisión de reivindicar los propios valores sobre aquellos de la comunidad internacional (en cuyo nombre se impusieron las sanciones) puede verse, precisamente, como el deslizadero de expresar o tener una voz hacia el escape. Y, por supuesto, existen formas menos románticas de catalogar este tipo de jurisprudencia. ${ }^{142}$

Un contexto intrigante que refleja un potencial deslizamiento de expresar o tener una voz hacia el escape puede encontrarse en el contexto suramericano. Mientras que la Corte Constitucional de Colombia usualmente examina la compatibilidad de las leyes nacionales con la jurisprudencia de la Corte $\mathrm{IDH}_{,}{ }^{143}$ en Venezuela, Bolivia y Ecuador, el auge de gobiernos populistas ha venido acompañado por la denuncia de la Convención Americana sobre Derechos Humanos (CADH) e, incluso, por la supresión de la jurisdicción de la Corte IDH sobre sus asuntos internos. ${ }^{144}$ La saga Fontevecchia en Argentina podría ubicarse en medio de estos dos extremos. La Corte Suprema de Justicia de la Nación argentina ha estado involucrada en una larga controversia acerca del derecho a la libertad de expresión con la Corte IDH. Jorge Fontevecchia y Héc-

142 Benvenisti y Downs ofrecen una explicación que apela a la malicia de las cortes: "enfrentados con el prospecto de que su competencia judicial continuaría reduciéndose como consecuencia de que una mayor proporción de la política regulatoria doméstica ahora es determinada por instituciones internacionales y de una mayor competencia por parte de tribunales internacionales, habría sido sorprendente si las cortes nacionales no hubiesen experimentado una sensación de riesgo en relación con su habilidad de desarrollar su rol constitucional tradicional [...] Aisladas de una mejor manera de las presiones domésticas e internacionales que realizan grupos de interés sobre las ramas políticas del poder, las cortes podrían ejercer presiones sobre sus gobiernos con el objeto de lograr una aprobación legislativa de sus acciones o bloquear ciertas políticas que sean incompatibles con normas de derecho constitucional e internacional". E. Benvenisti y G. W. Downs, "National courts, domestic democracy, and the evolution of international law", op. cit., p. 64.

143 Para una discusión en detalle, véase A. Huneeus, "Constitutional lawyers and the Inter-American Court's varies authority", en Law \& Contemporary Problems 79 (2016).

144 El 10 de septiembre de 2012, Venezuela denunció la Convención Americana sobre Derechos Humanos y se sustrajo a la competencia de la Corte IDH. El rival de Chávez en las urnas prometió dejar sin efectos la denuncia, pero su derrota significa que Venezuela ha abandonado, de manera definitiva, la jurisdicción de esa Corte. 
tor $\mathrm{D}^{\prime}$ Amico, el director y el editor de una revista argentina, fueron declarados civilmente responsables por cuenta de una serie de publicaciones relativas al hijo no reconocido del entonces presidente de Argentina, Carlos Saúl Menem. La Corte Suprema concluyó que la publicación de estos artículos quebrantó el derecho del presidente a la intimidad. ${ }^{145} \mathrm{La}$ Corte IDH sostuvo lo contrario y encontró que la información divulgada hacía parte del dominio público y eran un asunto de interés público para la fecha de los hechos. Por lo tanto, la declaración de responsabilidad en cabeza del editor y del medio infringió su derecho a la libertad de expresión. ${ }^{146}$ A la luz de esta sentencia, la Rama Ejecutiva de Argentina le solicitó a la Corte Suprema que la cumpliera y que revocara su decisión de 2001. En febrero de 2017, la Corte Suprema publicó una decisión en la cual afirmó que declinaba esta solicitud. La Corte Suprema declaró: "Se encuentra fuera de discusión que las sentencias de la Corte Interamericana, dictadas en procesos contenciosos contra el Estado argentino son, en principio, de cumplimiento obligatorio para este". Sin embargo, la Corte Suprema fue más allá e indicó que la Corte IDH no tenía la competencia de ordenar la revocatoria de providencias domésticas y que al hacer esto, esa Corte excedió su competencia bajo la CADH. ${ }^{147}$ Esta decisión, debe notarse, es de lejos más ofensiva que el caso Kadi dado que representa un desafío abierto a un tribunal internacional y se trata de una vuelta a los viejos argumentos soberanistas que resaltan la normatividad al estilo de Janos que exhibe la jurisprudencia de la tercera ola.

Kadi no es el único litigio que evoca una clara tensión entre órganos internacionales y cortes constitucionales sobre cuestiones de debido proceso y protección de los derechos fundamentales. Las dos sentencias que vienen a continuación son dos fallos nacionales que desafían a la CIJ y en los que las cortes nacionales actuaron, si se quiere, como instancias de apelación frente a una corte que, como se ha anotado, es de única y última instancia.

El 3 de febrero de 2012, la CIJ les solicitó a las cortes italianas la extensión de la inmunidad jurisdiccional a favor de Alemania por ciertas acciones que constituyen crímenes de guerra y delitos de lesa humanidad que vulneran los derechos humanos. Luego de la sentencia de la CIJ, el legislador italiano adoptó algunas disposiciones tendentes a implementar esa decisión. En la sentencia 238/2014, la Corte Constitucional de Italia explícitamente se abstuvo de cuestionar la validez de la interpretación acogida por la CIJ. Sin embargo, en la ratio decidendi de la sentencia la Corte estableció la obligación de adelantar control de constitucionalidad del derecho internacional consuetudinario como se observa en este pasaje: "Todas las reglas, actos y normas que tienen los mismos

145 Corte Suprema de Justicia de la Nación, Sentencia emitida el 26 de septiembre de 2001, en relación con los autos Menem /c Editorial Perfil SA y otros.

146 Corte IDH, Caso Fontevecchia y D’Amico v. Argentina, Fondo Reparaciones y Costas, Serie C, núm. $238,2011$.

147 Corte Suprema de Justicia de la Nación [CSJN], 14/2/2017, "Ministerio de Relaciones Exteriores y Culto s/ informe sentencia dictada en el caso (ibid.). 
efectos jurídicos que el derecho formal (ordinario o constitucional), pero cuyo nacimiento se produjo por medios distintos al procedimiento legislativo tradicional-lo cual incluye las mencionadas normas de [costumbre internacional]deben someterse al control de constitucionalidad concentrado" ${ }^{148}$

Una vez hecho esto, la Corte precisó el rango constitucional de las disposiciones de la ley por medio de la cual Italia ratificó la Carta de la Naciones Unidas, así como de la medida legislativa que alineó el orden jurídico de ese país con sus obligaciones internacionales derivadas de la Convención de las Naciones Unidas sobre las Inmunidades Jurisdiccionales de los Estados y de sus Bienes (2004). La Corte aseguró que en tanto la costumbre internacional es externa al orden jurídico italiano y su aplicación por los funcionarios estatales o los jueces es exigida por la Constitución, esta aplicación "debe seguir la interpretación que se le otorga en su sistema jurídico original, es decir, el sistema jurídico internacional". A pesar de esto, este caso presenta otra dificultad que tiene que ver con el conflicto que puede existir entre la norma de derecho internacional que tiene igual jerarquía que la Constitución (esto de conformidad con el reenvío que realiza el inciso 1 del artículo 10 de la Constitución) y los principios esenciales del orden constitucional (que incluyen el principio de protección de los derechos humanos fundamentales). "En estas situaciones, es competencia del juez nacional, y particularmente monopolio de esta Corte en virtud del control concentrado, realizar control de constitucionalidad con el fin de preservar la inviolabilidad de los principios del orden jurídico doméstico o, cuando menos, con el fin de minimizar su sacrificio". ${ }^{149}$

Dado que la Corte Constitucional tiene la obligación de asegurar el respeto por la Constitución y sus principios fundamentales, es también su deber verificar si la norma internacional que otorga a los Estados inmunidad frente a los juicios civiles que se adelanten por otros Estados es, en efecto, compatible con esos principios. La Corte definió el conflicto que tenía en sus manos como un choque entre, por una parte, la protección judicial efectiva de los derechos fundamentales y, por la otra, el derecho internacional, tal como fue definido por la CIJ. La Corte, en último término, resolvió el conflicto a favor de los principios fundamentales de la Constitución: "considerando que las normas sobre inmunidad frente a la jurisdicción de los Estados contravienen los principios fundamentales mencionados, esas normas no se han incorporado al sistema jurídico italiano y, por lo tanto, no tienen ningún efecto en el orden nacional". ${ }^{150}$

La Corte Constitucional italiana trató de ejercer un control constitucional doméstico sobre el órgano judicial internacional más importante y expresar su oposición a una norma internacional que afecta la protección de los derechos

148 Corte Costituzionale della Repubblica Italiana, Sentenza 238 del 22 ottobre 2014, párr. 2.1.
149 Ibid., párr. 3.1.

150 Ibid., párr. 3.5. 
humanos fundamentales. Aunque a lo largo de la decisión la Corte hace un esfuerzo por separar la supremacía de la CIJ al interpretar el derecho internacional y la supremacía de las cortes constitucionales al proteger los derechos al interior del orden jurídico constitucional nacional, también examina el posible rol que su intervención judicial puede jugar en caso de que otras cortes nacionales decidan unírsele $\mathrm{y}$, en conjunto, expresar su oposición colectiva que, eventualmente, puede transformarse en una nueva interpretación del derecho internacional.

Si bien la Corte Constitucional de Italia se abstuvo de ejercer un control de constitucionalidad directo sobre la sentencia de la CIJ, en todo caso presentó una interpretación alternativa del derecho internacional que regula la inmunidad de los Estados y que excluye casos categorizados como crímenes de guerra o de lesa humanidad de la jurisdicción de otros Estados. La Corte Constitucional consideró que esa exclusión constituye un quebrantamiento de los derechos humanos inviolables. Presentar una interpretación alternativa, declarar que una costumbre -tal y como ha sido interpretada por la CIJ- es inconstitucional e invitar a otras cortes a hacer lo mismo, es un intento de tener una voz y expresar una oposición al poder de la Corte mundial y de ofrecer un marco que limite e imponga controles al ejercicio de su autoridad judicial. Como era de esperarse, la sentencia de la Corte italiana generó una avalancha de opiniones y comentarios. La mayoría de ellos fueron negativos (con algunas pocas excepciones). En este escrito no queremos involucrarnos en esta controversia, sino mostrar un aspecto del caso que es del interés para nuestras tesis. La Corte Constitucional de Italia no se limitó a proponer un argumento basado simplemente en la soberanía, esto es, una suerte de juego de poder schmittiano entre lo internacional y lo doméstico. En su lugar, su argumento se fundó en valores (y no exclusivamente en los valores del orden jurídico italiano). Y dado que la CIJ es una corte tanto de primera como de última instancia, sin ninguna instancia de apelación significativa (algo que está en tensión con el sentido general de una buena administración de justicia), la Corte italiana se situó a sí misma, en efecto, como una instancia de apelación. Determinar si esta situación es algo positivo para la administración de justicia es una pregunta abierta a discusión. Lo que resulta interesante, sin embargo, es que se trata de un ejemplo claro de la relación dialéctica entre la tercera ola de jurisprudencia y sus predecesoras. El filósofo del derecho Gianluigi Palombella, en su trabajo sobre "interlegalidad", ha contribuido con lo que actualmente es uno de los intentos más sofisticados para explicar y ubicar este tipo de decisiones: no se trata de casos de "rebelión" o "desafío" judiciales, sino que, por el contrario, estas sentencias reflejan una jurisprudencia propia de un mundo mucho más complejo donde las jerarquías lineales tienen menos poder persuasivo. $Y$ esto es, en efecto, uno de los sellos distintivos de la tercera ola del control judicial. ${ }^{151}$

151 G. Palombella, "Interlegality and justice", 2017, en http://dx.doi.org/10.2139/ssrn.3066001. 
Un intento más directo de emplear el control judicial sobre una opinión consultiva de la CIJ es el caso israelí sobre la legalidad del muro (Mara'abe). ${ }^{152}$ Como su par italiana, la Corte Suprema de Israel fue deferente con la interpretación del derecho internacional propuesta por la CIJ ("la sentencia de la Corte Internacional de Justicia contiene una interpretación de derecho internacional hecha por el órgano judicial de más jerarquía en el derecho internacional [...] A la interpretación de la CIJ debería dársele la importancia y peso correspondientes"). ${ }^{153}$ La controversia, no obstante, tuvo que ver con los hechos del caso:

La principal divergencia entre las dos decisiones se deriva, primordialmente, de la diferencia con la cual cada corte se aproximó a la base factual sobre la cual cada tribunal construyó su decisión. Una vez más se prueba una simple verdad: los hechos yacen en la base del Derecho y el Derecho surge de los hechos (ex facto jus oritur). La CIJ definió la base factual de su opinión a partir del reporte del Secretario General, de la declaración que este rindió por escrito, del reporte Dugard y del reporte Zeigler. La Corte Suprema derivó los hechos de la información que fue presentada por los recurrentes palestinos, por un lado, y el Estado por otra parte. Adicionalmente, la Corte Suprema recibió un dictamen de expertos remitido por militares especialistas quienes solicitaron la oportunidad de presentar su posición a través de un amicus curiae. A pesar de que la información que cada corte recibió se refiere al mismo muro, las diferencias entre cada grupo de datos son profundas e inmensas. Estas diferencias fueron, en último término, el factor que produjo que cada corte arribara a conclusiones jurídicas opuestas. ${ }^{154}$

La Corte Suprema de Israel emprendió un diálogo abierto con la CIJ y resaltó algunos aspectos de sus decisiones que consideró oportuno repasar. Es precisamente este intento por parte de una corte suprema de tener una voz o expresar una perspectiva alternativa relativa a la aplicación del derecho internacional, el que impone alguna especie de límites sobre la CIJ y el ejercicio de su poder. A diferencia de la Corte italiana, la Suprema Corte de Israel critica directamente el proceso decisorio de la CIJ. Además, la Corte Suprema sostiene que, dado que la base factual a la mano de cada una de las dos cortes es diferente, no está obligada a seguir una de ellas. ${ }^{155}$

Así, tanto la Corte italiana, como la Corte Suprema israelí, declinan el cumplimiento de las decisiones de la CIJ y fundan sus determinaciones o bien sobre bases principialísticas/normativas (la Corte italiana), o sobre bases procedimentales/metodológicas (la Corte israelí). Sea como fuere, nos parece que esta clase de oposición judicial, junto con la amenaza de no cumplimiento, representan un ejercicio de escape por parte de las cortes. Tales casos de escape plantean una amenaza significativa a la autoridad de la CIJ y, en ese sentido, pueden convertirse en un control poderoso y efectivo sobre esta, siempre que el ejer- 
cicio de su autoridad se considere incompatible con los principios centrales de los órdenes constitucionales domésticos. La normatividad se complejiza y esto es patente: este diálogo e interacciones entre las cortes puede amenazar con el debilitamiento de un cuerpo judicial ya relativamente domesticado y de un orden jurídico internacional desgastado. Sin embargo, al mismo tiempo, se presenta una oportunidad muy importante para que los actores rindan cuentas y encuentren límites en el Estado de derecho. Y, por supuesto, el impacto de estas decisiones -que es negativo y positivo- va mucho más allá de estos casos específicos producidos en un universo judicial que está acostumbrado simplemente a la "copia" de jurisprudencia.

\section{La democracia y la manifestación del desafío mayoritario de la tercera ola}

La cartografía de una primera y segunda olas describe con mucha claridad la realidad evolucionaria de Europa en donde, en algunas ocasiones, como ocurrió al comienzo de la década de los setenta en casos como Frontini, Le Ski e Internationale Handelsgesellschaft, las cortes buscaron por todas partes fórmulas para ajustar su entendimiento sobre lo que debía ser el control de constitucionalidad doméstico o acerca de lo que debían ser las relaciones entre el derecho de la Unión y el Derecho nacional. Igualmente, las golondrinas que presagiaban una tercera ola aparecieron bastante rápido en el horizonte del orden jurídico europeo. Las cortes constitucionales nacionales mostraron su resistencia a la noción de la supremacía del derecho de la UE sobre todas las disposiciones de derecho nacional. Uno de los primeros y más famosos episodios en esta controversia fue la decisión del caso Solange, proferida por el Tribunal Constitucional Federal alemán en 1974:

... La Comunidad aún carece de un parlamento legítimo, electo directamente por el voto universal, que tenga la capacidad de legislar y al cual los órganos de la Comunidad pudieran conferir poder legislativo y ser políticamente responsables por las acciones de ese parlamento [...] En la medida en que esta seguridad jurídica [...] no se logre en el transcurso de una integración más profunda de la Comunidad, la reserva que se deriva del artículo 24 de la Constitución es aplicable. ${ }^{156}$

La saga Solange reapareció recientemente en la jurisprudencia heterodoxa expedida por varias cortes pero, más prominentemente, por el Tribunal Constitucional Federal alemán cuando examinó las credenciales democráticas del sistema jurídico europeo. En una serie de casos-Maastricht, la decisión del caso Banana Market, Lisboa, Mangold-Honeywell y OMT-el Tribunal Constitucional abordó el problema de la identidad constitucional nacional. En la decisión

156 European Court of Justice, Internationale Handelsgesellschaft mbH v Einfuhr- und Vorratsstelle für Getreide und Futtermittel. Reference for a preliminary ruling: Verwaltungsgericht Frankfurt am Main, Germany, ECLI:EU:C:1970:114, 1970, párr. 23. 
del caso Maastricht (1993), el Tribunal aclaró que mientras no se afrontara el asunto del déficit democrático, existían límites a la delegación constitucional hacia el nivel europeo. ${ }^{157}$ En la sentencia del caso Lisboa, el Tribunal Federal no estableció límites fundados en circunstancias contingentes a dicha delegación, pero sostuvo que las autoridades alemanas no pueden "transferir derechos de soberanía de modo tal que el ejercicio de la misma [sic] permita fundamentar otras competencias para la Unión Europea de forma independiente" ${ }^{158}$ Es más, la decisión en el caso de Lisboa prohíbe la transferencia de la KompetenzKompetenz judicial: "Constituye una consecuencia de la soberanía que mantienen los Estados miembros el que la inaplicabilidad de un cierto acto jurídico en Alemania pueda ser determinada por el Tribunal Constitucional Federal, al menos cuando sea manifiesta la carencia de la orden constitutiva de aplicación del Derecho del Tratado". ${ }^{159} \mathrm{El}$ Tribunal enfatizó aún más en la noción relacionada de la Constitución de Alemania como no derogable:

La Ley Fundamental habilita ciertamente al legislador para proceder a una amplia transferencia de derechos de soberanía a la Unión Europea. Sin embargo, dicha autorización está sujeta a la condición de que se mantenga garantizada la estatalidad constitucional soberana sobre la base de un programa de integración conforme con el principio de atribución de competencias y que respete la identidad constitucional de los Estados miembros y, al mismo tiempo, que los Estados miembros no pierdan su capacidad de configuración política y social de las condiciones de vida bajo su propia responsabilidad. ${ }^{160}$

El Tribunal construyó su noción de la supremacía del orden constitucional alemán frente al orden jurídico europeo sobre principios democráticos y sobre el déficit democrático a nivel de la Unión Europea: “Un fortalecimiento de la integración puede ser inconstitucional si el nivel de legitimación democrática no es coherente con el alcance y la importancia del poder político supranacional". ${ }^{161}$ Aunque el Tribunal Constitucional exploró los elementos que hacen, a su jui-

157 Bundesverfassungsgericht (Tribunal Constitucional Federal de Alemania), BVerfGE 89, 155 - Maastricht, I.L.M. 388, 395, 1993; G. Wegen y C. Kuner, “Germany: Federal constitutional court decision concerning the Maastricht Treaty", en International Legal Materials 33 (2) (1994).

158 Bundesverfassungsgericht (Tribunal Constitucional Federal de Alemania), BvE 2/08 - Lisbon, 2009. Para mayor información, véase J. Arato, "A preemptive strike against European Federalism: The decision of the Bundesverfassungsgericht concerning the treaty of Lisbon" [blog], EJIL Unbound, 2010. https://www.ejiltalk. org/a-preemptive-strike-against-european-federalism-the-decision-of-the-bundesverfassungsgericht-concerning-the-treaty-of-lisbon/

159 Bundesverfassungsgericht (Tribunal Constitucional Federal de Alemania), BvE 2/08 - Lisbon, párr. 339. En casos posteriores, el Tribunal Constitucional aclaró aún más el significado de la expresión “identidad constitucional". Véase, por ejemplo, Bundesverfassungsgericht (Tribunal Constitucional Federal de Alemania), BvR 256/08 (Data Retention), 2010. El Tribunal analizó la directiva de la Unión Europea sobre conservación de datos y concluyó que la libertad individual dispone que no toda pieza de comunicación puede ser grabada y registrada en su totalidad. Con base en este argumento, el Tribunal declaró la inconstitucionalidad de un acto del parlamento que implementó la directiva europea sobre conservación de datos; Bundesverfassungsgericht (Tribunal Constitucional Federal de Alemania), BVerfGE 129 (E.F.S.F.) , 2011. (el Bundestag no puede ver limitada su autonomía presupuestal por cuenta de acuerdos que aceptan la responsabilidad financiera de terceros, responsabilidad cuyos efectos no son fáciles de calcular).

160 Bundesverfassungsgericht (Tribunal Constitucional Federal de Alemania), BvE 2/08 - Lisbon, párr. $226 e$.

161 Ibid., párr. 262a. 
cio, que el diseño institucional de la UE sea democráticamente deficiente, ${ }^{162}$ consideró en todo caso que esos elementos eran normativamente deseables:

En tanto que órgano de representación de los pueblos en una comunidad supranacional, caracterizada como tal por una voluntad de unidad limitada, el Parlamento Europeo en su composición no puede ni debe corresponder a los requerimientos que a nivel estatal se derivan del mismo derecho político de sufragio de todos los ciudadanos. La Comisión, en tanto que órgano supranacional específico, tampoco necesita cumplir en toda su extensión las condiciones de un gobierno plenamente responsable ante el Parlamento o ante la decisión mayoritaria de los electores, porque la propia Comisión no depende de manera comparable de la voluntad del elector. ${ }^{163}$

De este modo, dado que los procedimientos democráticos de la UE son inherentemente deficientes (en comparación con aquellos de los Estados), estos no son suficientes para fundamentar cualquier aspiración de democracia soberana. La participación y la transparencia no pueden reemplazar a las elecciones:

... el Tratado de Lisboa no conduce a un nuevo nivel de desarrollo de la democracia. Los elementos de la democracia participativa, como la exigencia de dar a los ciudadanos de la Unión y a las asociaciones "representativas" la oportunidad de plantear sus puntos de vista, así como los elementos de la democracia asociativa y directa solo pueden tener una función complementaria en la legitimación del poder público europeo, pero no juegan un papel fundamental. ${ }^{164}$

Los Estados, por lo tanto, deben retener un "margen de acción política suficiente para configurar [sus] condiciones de vida económicas, culturales y sociales". Esto es particularmente relevante en aquellas áreas que

... determinan las circunstancias vitales de los ciudadanos, en particular su espacio privado (protegido por los derechos fundamentales) y de seguridad personal y social, que está bajo su propia responsabilidad. Lo mismo ha de afirmarse respecto a las decisiones políticas que dependen especialmente de concepciones previas de aspectos culturales, históricos y lingüísticos particulares y que se adoptan en un proceso de discusión política en un espacio público organizado por el régimen parlamentario y por los partidos políticos. ${ }^{165}$

El Tribunal concluyó, además, que el derecho alemán prevalece y que existe la posibilidad -bajo circunstancias excepcionales, especiales y precisas-, de que el Tribunal Constitucional Federal declare la inaplicabilidad del derecho

162 "A diferencia de la organización de un Estado federal, el Consejo a nivel europeo no es una segunda cámara, sino el órgano de representación de los 'señores de los Tratados' y, por consiguiente, no está constituido según la representación proporcional, sino de conformidad con el principio de la igualdad entre los Estados miembros. El Parlamento Europeo, como órgano de representación de los pueblos elegido directamente por los ciudadanos de la Unión, constituye una fuente adicional autónoma de legitimación democrática" (ibid., párr. 271).

164 Ibid., párr. 294.

165 Ibid., párr. 249cc 
europeo en Alemania. Curiosamente, el Tribunal advirtió que la CEJ, en su sentencia en el caso Kadi, empleó el mismo argumento de la primacía del orden nacional en relación con el orden jurídico internacional:

El Tribunal de Justicia de las Comunidades Europeas se basó en un razonamiento análogo en la decisión de 3 de septiembre de 2008 en el caso Kadi, según la cual los principios fundamentales del ordenamiento de la Comunidad pueden ser opuestos a la pretensión de aplicabilidad conforme al Derecho internacional de una Resolución del Consejo de Seguridad de Naciones Unidas. De este modo, el Tribunal de Justicia, ha puesto en una situación límite, la preservación de la propia identidad como una comunidad [jurídica] por encima del compromiso que de otra manera sería respetado: tal figura jurídica no solo es conocida en las relaciones jurídicas internacionales como invocación del ordre public como límite a un compromiso adquirido en virtud de un Tratado; también se corresponde -al menos utilizado de manera constructivacon la idea de las relaciones políticas de ordenamiento que no están estructurados según una jerarquía estricta. ${ }^{166}$

En el caso de Lisboa, por tanto, el Tribunal definió el principio democrático como un principio inviolable. "El poder constituyente de los alemanes que se otorgó la Ley Fundamental pretendió establecer un límite infranqueable a todo desarrollo político ulterior [...] Con ello la Ley Fundamental no solo presupone, sino que garantiza, la condición de Estado soberano de Alemania". ${ }^{167}$

Dentro de las muchas características de esta decisión tan criticada se encuentra, a nuestro juicio, su preocupación loable no solo por la jerarquía constitucional de las normas (v. gr., si el derecho internacional es superior al derecho nacional; si el derecho europeo es superior al derecho de los Estados miembros), sino también sus preocupaciones referentes al origen democrático de la norma internacional. Estas preocupaciones, desde nuestro punto de vista, no representan simplemente un argumento tradicional formulado desde la soberanía, sino una aproximación mucho más matizada a la gramática de la legitimidad en la vida contemporánea. Otro punto interesante fue el claro ejemplo de los efectos de fertilización cruzada horizontal (i. e., la referencia a Kadi) y, tal vez más interesante aún, fue ver el comienzo de una preocupación más explícita por la identidad (constitucional) de la comunidad política de la cual una corte es su guardiana.

\section{La identidad como un escape de la tercera ola}

La resistencia por parte de jurisdicciones domésticas a las normas internacionales es, por supuesto, un fenómeno común y transversal a varias jurisdicciones y que se produce en diferentes momentos, como acabamos de ver. De manera convencional, el aparato jurisprudencial y su concomitante vocabulario se en-

166 Ibid., párr. 340.

167 Ibid., párr. 216c. 
focaban en la noción de soberanía y en una lógica subyacente schmittiana que indagaba "en manos de quién debe estar la última palabra". Lo que se puede notar, como parte de la tercera ola, es la introducción de una nueva línea de razonamiento y justificación que recurre al vocabulario de la "identidad".

El uso de la identidad típicamente no se especifica y a menudo da la impresión de que se trata de un tropo; algo que se utiliza para, quizás, conferirle un aspecto más aceptable al uso crudo y desde el simple poderío que usualmente se le da a la soberanía. Sin embargo, este uso puede ser, al mismo tiempo, una expresión de una sensibilidad genuina. Una lectura alternativa de la jurisprudencia Lisboa que ya examinamos y que se preocupa por cuestiones relacionadas con el déficit democrático, sería aquella en la que se resalte este tipo de decisiones como una evolución hacia el asunto de la identidad en el pensamiento constitucional. Esta nueva sensibilidad puede encontrarse, por ejemplo, en los tratados de la UE que recientemente han consagrado la "identidad nacional" de los Estados miembros como un valor que debe protegerse: ${ }^{168}$ en este caso, las disposiciones de la Constitución (típicamente en el área de derechos humanos) no están allí solo para proteger al individuo frente a los intereses colectivos (como ocurre en la concepción clásica), sino que, simultáneamente, representan un indicador cultural e identitario de la colectividad propiamente dicha, identidad que debe ser protegida por las cortes constitucionales. La relevancia de la identidad nacional como parámetro clave se refleja en el hecho de su inclusión tan prominente en el Tratado de Lisboa. Es necesario hacer énfasis en la importancia de esta línea jurisprudencial dado que esta, de alguna manera, separa la protección de los derechos humanos de sus anclajes clásicos (el individuo versus el Estado/nación/autoridad pública) y la reconfigura, al mismo tiempo, como una expresión de la identidad del Estado y de la nación, lo que produce una tensión compleja que no es de fácil resolución. El lenguaje de la identidad constitucional y nacional nos permite entender las concepciones nacionales de los derechos humanos establecidas a nivel internacional, no simplemente como un mero conflicto con las normas internacionales de derecho positivo, sino como una forma de preservar la identidad cultural, social y política. Esta reconceptualización de los derechos es útil para justificar una voz alternativa $\mathrm{o}$, in extremis, un escape de una manifestación específica del sistema jurídico y de valores internacional.

Esta manifestación tendrá lugar, invariablemente, en un contexto en el que la jurisdicción doméstica prefiera su propia concepción de los derechos hu-

168 Luego de la reforma por cuenta del Tratado de Lisboa, el Tratado de la Unión Europea (TUE) le da un peso considerable al concepto de identidad nacional. El artículo 4(2) dispone lo siguiente: “La Unión respetará la igualdad de los Estados miembros ante los Tratados, así como su identidad nacional, inherente a las estructuras fundamentales políticas y constitucionales de éstos, también en lo referente a la autonomía local y regional. Respetará las funciones esenciales del Estado, especialmente las que tienen por objeto garantizar su integridad territorial, mantener el orden público y salvaguardar la seguridad nacional. En particular, la seguridad nacional seguirá siendo responsabilidad exclusiva de cada Estado miembro". 
manos a aquella requerida (jimpuesta!) por las normas internacionales. Es en este sentido que planteamos este aspecto de la tercera ola como una reacción a la segunda ola.

En ocasiones, las manifestaciones de este cambio pueden hallarse en frases o palabras extrañas o de rara ocurrencia que, a nuestro juicio, no deberían descartarse simplemente por ser anecdóticas o insignificantes. Estas frases y palabras son las precursoras de una nueva sensibilidad en expansión.

Los siguientes ejemplos ilustran el tránsito de una aproximación soberanista clásica hacia una aproximación más contemporánea en la cual el ingrediente identitario se ha vuelto una parte integral del razonamiento.

Nuestro primer caso echa mano de la jurisprudencia comparada producida alrededor de Lisboa que mencionamos antes. Esta vez, sin embargo, resaltaremos sus características identitarias. Tomemos la sentencia del Tribunal Constitucional de Polonia del 11 de mayo de $2005,{ }^{169}$ que afirmó el principio de la supremacía última del derecho constitucional polaco sobre el derecho de la EU en una decisión poco notable y en conversación con la doctrina sentada por muchas otras cortes en Europa. Este es el lenguaje de interés:

1. El acceso de Polonia a la Unión Europea no debilitó la supremacía de la Constitución sobre todo el sistema jurídico existente al interior de la órbita de soberanía de la República de Polonia. Las normas de la Constitución, que constituyen el acto supremo por el cual se expresa la voluntad de la Nación, no pierden su fuerza vinculante o cambian su contenido por el mero hecho de la existencia de una inconsistencia irreconciliable entre estas normas constitucionales y cualquier disposición de la Comunidad. En tal situación, la decisión autónoma sobre la forma en la cual se debe resolver esta inconsistencia, incluyendo la conveniencia de reformar la Constitución, le pertenece al constituyente polaco.

$[\ldots]$

29. El matrimonio, que es la unión de un hombre con una mujer, ha adquirido un estatus constitucional singular en el orden jurídico doméstico de la República de Polonia con fundamento en el artículo 18 de la Constitución. Cualquier modificación de este estatus solo puede ser posible mediante una reforma a la Constitución (de conformidad con el artículo 235 de la misma); bajo ninguna circunstancia este estatus puede modificarse por medio de un acuerdo internacional debidamente ratificado.

Ahora bien, comparemos este pronunciamiento con otra decisión de este mismo Tribunal. Se trata de la sentencia del 24 de noviembre de 2010 (esto es,

169 Trybunał Konstytucyjny (Tribunal Constitucional de Polonia), Wyrok, Trybunału Konstytucyjnego, z dnia 11 maja 2005 r. (Constitutionality of the Accession Treaty) K 18/04, 2010. 
expedida cinco años después) sobre la constitucionalidad del Tratado de Lisboa. ${ }^{170}$ Aunque la posición dogmática-jurídica subyacente en relación con la jerarquía de las normas no cambió, el lenguaje tiene unos matices diferentes.

1.1.2 [...] la presunción de constitucionalidad del Tratado solo puede desvirtuarse luego concluir que no existe ninguna interpretación posible del Tratado y ninguna interpretación posible de la Constitución que le permita al Estado lograr cierta consistencia entre las disposiciones del Tratado y las de la Constitución. El Tribunal Constitucional no puede desconocer el contexto de los efectos de su fallo, desde la perspectiva de los principios y valores constitucionales, así como tampoco las consecuencias de su sentencia sobre la soberanía del Estado y su identidad constitucional.

2.1 [...] Desde el punto de vista del Tribunal Constitucional, la soberanía de la República de Polonia y su independencia -entendida como separabilidad de la categoría de Polonia como un Estado al interior de sus fronteras y bajo las circunstancias que se derivan de su membresía a la UE de conformidad con las reglas indicadas en la Constitución-implica la confirmación de la primacía de la Nación polaca a la hora de definir su propio destino. La manifestación normativa de este principio es la Constitución y, particularmente, el Preámbulo y sus artículos 2, 4, 5, 8, 90,140(2) y 126(1), a la luz de los cuales la soberanía de la República de Polonia se expresa en las competencias inalienables de los órganos del estado y que constituyen la identidad del Estado...

El Tribunal Constitucional comparte la opinión expresada en la doctrina según la cual las competencias cuyo otorgamiento se prohíbe, manifiestan una identidad constitucional y, así, reflejan los valores sobre los cuales se funda la Constitución...Por consiguiente, la identidad constitucional es un concepto que ordena "excluir, de la competencia de otorgar competencias, los asuntos que constituyen (...) 'el corazón o núcleo de la materia», i.e., que son fundamentales y están a la base del sistema político de un Estado dado' [...]

Independientemente de las dificultades que conlleva la fijación de un catálogo detallado de competencias inalienables, las siguientes materias deben incluirse dentro de los asuntos sobre los que pesa una prohibición absoluta de otorgamiento o delegación: las decisiones que especifican los principios fundamentales de la Constitución y las decisiones que se refieren a los derechos del individuo, determinan la identidad del Estado. [Énfasis agregado, se omiten las referencias] ${ }^{171}$

Preferimos no tomar ningún tipo de posición normativa a la luz de esta discusión. La identidad puede ser usada o abusada en el razonamiento político y constitucional. Sin embargo, sostenemos, como mencionamos atrás, que la identidad tiene una resonancia con el anhelo arraigado de la singularidad del individuo humano y situamos este anhelo en el territorio normativo de la dignidad humana. Este giro hacia la identidad en la jurisprudencia de las cortes de alrededor del mundo es una exhibición, más o menos sincera, reac-

170 Trybunał Konstytucyjny (Tribunal Constitucional de Polonia), Wyrok. Trybunału Konstytucyjnego, z dnia 24 listopada 2010 r. (Constitutionality of the Treaty of Lisbon),K 32/09, 2010.

171 En el mismo sentido, véase Trybunał Konstytucyjny (Tribunal Constitucional de Polonia), Wyrok, Trybunału Konstytucyjnego, z dnia 16 listopada 2011 r. (Constitutionality of the Council Regulation (EC) No. 44/2001 of December 22, 2000, on jurisdiction and the recognition and enforcement of judgments in civil and commercial matters), SK 45/09, 2000. 
tiva o constitutiva, de esta sensibilidad social y política. Es posible encontrar desarrollos semejantes en otras jurisdicciones. En la República Checa, se puede comparar la sentencia de la Corte Constitucional de noviembre de 2008, ${ }^{172}$ con una decisión de ese mismo Tribunal proferida un año después y en la que el vocabulario de la identidad se desliza sigilosamente. ${ }^{173}$

Un cambio de aproximación, desde la soberanía hacia los valores nacionales, se puede en principio detectar si se compara el fallo del Tribunal Constitucional español de diciembre de 2004 -en el que se examinó la difunta Constitución de Europa- y su sentencia, diez años después, de febrero de 2014, que hace parte de la saga Melloni y que vamos a bordar con posterioridad. ${ }^{174}$

En el dilema que existe entre un escape y tener una voz, el giro de las cortes hacia la identidad en el conjunto de decisiones que se han analizado constituye un intento por establecer un límite infranqueable que sus ordenamientos constitucionales no pueden cruzar en favor de normas y fallos internacionales. Nos referiremos a este límite constitucional infranqueable frente a lo internacional en tanto identidad como escape. Esta modalidad de identidad como escape ha sido ilustrada de forma ejemplar por alguna jurisprudencia del Reino Unido que se refiere al TEDH. En dos fallos hito del TEDH -Hirst v. United Kingdom (No. 2) y Scoppola v. Italy (No. 3) (2012)-, la Gran Sala concluyó que la decisión británica de prohibir el derecho al voto para los reclusos era incompatible con el artículo 3 del Protocolo 1 de la CEDH..${ }^{175}$ La Corte Suprema del Reino Unido, de una manera muy respetable y persuasiva, articuló una doctrina por la cual, cuando una decisión del TEDH efectúa una lectura errónea de algunas características del sistema jurídico británico, existe una justificación para apartarse de la decisión o del precedente sentado en Estrasburgo.

Puede haber, sin embargo, algunas ocasiones excepcionales en las que esta corte tenga algunas preocupaciones acerca de si una decisión de la Corte de Estrasburgo aprecia o acomoda suficientemente ciertos aspectos de nuestro proceso doméstico. En tales circunstancias, es potestad de esta corte abstenerse de seguir el fallo emitido en Estrasburgo, ofreciendo, en todo caso, las razones por las cuales se toma esta decisión. Esto puede dar lugar a que la Corte de Estrasburgo reconsidere el aspecto

172 Ústavní soud České republiky (Corte Constitucional de la República Checa), Lisabonská smlouva pozměňující Smlouvu o Evropské unii a Smlouvu o založení Evropského společenství. Pl.ÚS 19/08 ze dne 26. 11. 2008 (Constitutionality of the Treaty of Lisbon I), 446/2008 Sb. - N 201/51 SbNU 445, 2008.

173 Ústavní soud České republiky (Corte Constitucional de la República Checa), Lisabonská smlouva pozměňující Smlouvu o Evropské unii a Smlouvu o založení Evropského společenství II. Pl.ÚS 29/09 ze dne 3. 11. 2009 (Constitutionality of the Treaty of Lisbon II), N 233/55 SbNU 197, 2009. “Sin embargo, la Corte Constitucional asume que una situación como esta puede ocurrir, únicamente, en casos realmente excepcionales. Estos casos pueden incluir, específicamente, el abandono de la identidad de los valores y, como ya se ha anotado, la extralimitación de las competencias otorgadas"

174 Tribunal Constitucional de España, Declaración 1/2004, BOE núm. 3, de 04 de enero de 2005. Cfr. Tribunal Constitucional de España, Sentencia 26/2014, BOE núm. 60, de 11 de marzo de 2014

European Court of Human Rights, Hirst v. United Kingdom (No. 2), 2005-IX, 42 E.H.R.R. 41, 2005. 
específico que se debate, de tal manera que se produzca un diálogo fructífero entre esta corte y la Corte de Estrasburgo. ${ }^{176}$

Esto puede compararse con el siguiente pasaje: “De este modo, la Corte seguirá la jurisprudencia de Estrasburgo si 1) existe un precedente claro y consistente por parte del TEDH, 2) que no sea incompatible con una característica fundamental del derecho doméstico, y 3) en el que su razonamiento tenga en cuenta todos los argumentos relevantes". ${ }^{177}$

Debemos notar en estos fragmentos la afirmación de principio relativa a unas vagas "características fundamentales" -algo abstracto, por oposición a una regla específica de derecho- como la razón clave para rechazar la obligatoriedad del precedente internacional. No obstante, en la tercera condición podemos percibir algún eco de las sentencias de las cortes italiana e israelí, eco que le permite a la Corte Suprema del Reino Unido considerarse competente para revisar la adecuación del razonamiento del TEDH. Los dictámenes de las cortes de Israel e Italia ejemplifican tanto la manifestación democrática de la tercera ola, como la manifestación de la identidad como escape.

En el otoño de 2017, el gobierno de Theresa May logró un acuerdo según el cual algo menos de 100 reclusos, con penas cortas, tendrían la posibilidad de votar cuando estuviesen fuera de la prisión por cuenta de un permiso de salida temporal. David Lidington, secretario de Justicia, señaló lo siguiente: "Creemos que estas modificaciones abordan los puntos que surgieron con el fallo de 2005 y lo hacen de una forma que respeta las indicaciones de parlamentos sucesivos y de las opiniones enraizadas del público británico sobre el voto de reclusos". ${ }^{178}$ Todos estos eventos alrededor del derecho al voto de los presidiarios se relacionan, directamente, con preguntas sobre la democracia y la identidad democrática (en lugar de los derechos). Aunque debe decirse que el principal reparo a una posible reforma bajo el argumento de la "identidad democrática" británica no lo propuso la judicatura, sino que se hizo en el marco de las deliberaciones parlamentarias y los comités gubernamentales. ${ }^{179}$

La complejidad normativa de la identidad como escape es evidente también. "Características fundamentales" excepcionales pueden fácilmente transformase en un rechazo integral. Lord Hoffman, un antiguo miembro de la Corte Suprema, observó lo siguiente en un contexto no judicial:

176 Supreme Court of the United Kingdom, R v Horncastle \& Others, UKSC 14, 2009

177 Supreme Court of the United Kingdom, R (on the application of Chester) (Appellant) v Secretary of State for Justice (Respondent), U.K.S.C. 63, 2013.

178 A. Travis, "Up to 100 prisoners on short sentences to be given right to vote", The Guardian, en http://www. theguardian.com/society/2017/nov/02/up-to-100-prisoners-on-short-sentences-to-be-given-right-to-vote.

179 Para mayor análisis véase, por ejemplo, S. Foster, "Reluctantly restoring rights: Responding to the prisoner's right to vote", en Human Rights Law Review 9 (3) (2009). A pesar de esta clara controversia, las cortes británicas y europeas acogen una concepción más bien limitada de la democracia que enfatiza el derecho al voto. Una concepción alternativa y una crítica de ambas posturas puede encontrarse en P. Ramsay, "Faking democracy with prisoners' voting rights", en LSE Legal Studies Working Paper (2013). 
25. Es un hecho notable que durante la redacción y negociación de la Convención Europea [...] nadie parece haberse percatado y llamado la atención sobre el defecto básico que supone el concepto de una corte internacional de derechos humanos que decide sobre la aplicación concreta de esos derechos en diferentes países.

$36[\ldots]$ No puede ser que el balance al que debemos llegar en nuestro país sobre las tensiones entre la libertad de prensa y el derecho a la intimidad, deba ser decidido por una afirmación de un juez esloveno relativa a una sentencia del Tribunal Constitucional alemán:

“Creo que las cortes, hasta cierto punto y bajo la influencia de Estados Unidos, han fetichizado la libertad de prensa... ¿Es hora de que el péndulo regrese y se logre un equilibrio diferente entre lo que es privado y protegido y lo que es público y abierto?" (se cita la opinión concurrente del juez Zupanyič en Von Hannover v Alemania (24 de junio de 2004).

$[\ldots]$

39 [...] Como evidencia la jurisprudencia, no hay virtualmente ningún aspecto de nuestro ordenamiento jurídico -desde el derecho de propiedad, hasta la seguridad social, la responsabilidad civil extracontractual y el derecho de los contratos- que no haya sido permeado en algún punto por los derechos humanos. Sin embargo, no hemos renunciado aún a nuestra soberanía sobre estos asuntos. Aún somos una nación independiente con su sistema jurídico propio que ha evolucionado a lo largo de varios siglos de luchas constitucionales y cambios pragmáticos. No estoy sugiriendo que el sistema jurídico del Reino Unido sea perfecto. Lo que sostengo es que las decisiones detalladas sobre cómo este se podría mejorar deberían tomarse en Londres, bien sea por nuestras instituciones democráticas o por instituciones judiciales que, como la Corte Suprema de Estados Unidos, son parte integral de la sociedad y respetadas en sí mismas. (Énfasis agregado) ${ }^{180}$

La última consideración británica que quisiéramos resaltar para ejemplificar la identidad como escape puede encontrarse en el Manifiesto del Partido Conservador para las elecciones de 2015:

El próximo gobierno conservador va a abandonar el Acta de los Derechos Humanos e introducir una carta de derechos británica. Esto romperá el vínculo formal entre las cortes británicas y el Tribunal Europeo de Derechos Humanos. Así, nuestra propia Corte Suprema será el árbitro final de los asuntos atinentes a derechos humanos en el Reino Unido. (p. 60)

No es posible tratar la cuestión de la identidad en la jurisprudencia constitucional sin referirse a una decisión del Tribunal Constitucional alemán y su variación del principio Melloni. Este es un fallo bien conocido y ofrece una de las ilustraciones más explícitas de una invocación a la "identidad constitucional". Luego de dejar atrás su típica postura de expresar su voz y después de asumir

180 L. H. Hoffmann, "Speech by Lord Hoffmann: The Universality of Human Rights", 2009, en https://www. judiciary.uk/announcements/speech-by-lord-hoffmann-the-universality-of-human-rights/. 
una clara opción hacia el escape, el Tribunal alemán efectivamente desafió a la Corte Europea de Justicia al no respetar la famosa Orden Europea de Arresto y al negarse a aprobar una solicitud de extradición a Italia de una persona que fue juzgada en ausencia porque, bajo el derecho italiano, esta persona no tendría una audiencia de evidencias en el sistema procesal de apelaciones. Según el derecho alemán, esto quebrantaría los derechos del procesado a un mínimo de justicia y al así denominado principio de culpa, que se deriva de lo más sagrado del constitucionalismo alemán: la dignidad humana. ${ }^{181}$

Desde nuestra perspectiva, lo que resulta relevante es el uso explícito de la noción no especificada de "identidad constitucional" como eje del razonamiento. A pesar de su ausencia de especificación y dado el gran prestigio y gravitas del Tribunal Constitucional de Alemania adquiridos merecidamente gracias a los desarrollos cuidadosos y a la argumentación meticulosa de sus sentencias, la noción de identidad ha madurado y, con esa pátina de legitimidad, se ha profundizado mediante una decisión en la cual el Tribunal no solo ha "ladrado", sino también "mordido". Es de esperarse que esta sentencia se convierta en un hito de la jurisprudencia constitucional en jurisdicciones remotas. Ahora, existe algún grado de ironía si se considera la decisión desafiante ya mencionada de la Corte Constitucional italiana y que desató la ira de la mayoría del establecimiento jurídico alemán. A un nivel profundo, las dos decisiones (las de las cortes italiana y alemana) son similares: ambas privilegian valores sustantivos y un fuerte argumento identitario (¿qué clase de sociedad somos?) sobre principios constitucionales sistémicos y procesales (muy importantes y valiosos en sí mismos). Ambas sentencias muestran la naturaleza normativa compleja de este tipo de jurisprudencia de la tercera ola. Hay, por ello, alguna suerte de hipocresía cuando se condena abiertamente una de esas decisiones, mientras se guarda silencio respecto de la otra.

Una tensión complicada y con muchos matices entre un derecho frente a otro derecho (en la que tener una voz y el diálogo son esenciales) puede convertirse en un conflicto mucho más agudo entre un derecho vs. una infracción del derecho y puede desembocar en un escape. Este conflicto más dramático lo ponen de presente las palabras de otro exjuez (y presidente de la República de Alemania).

Se dice que Roman Herzog y Lüder Gerken señalaron lo siguiente en Stop the European Court of Justice:

La adjudicación judicial en Europa está en graves problemas. La razón se halla en la misma Corte Europea de Justicia (CEJ) cuyas justificaciones para privar a los Estados miembros de sus propias competencias fundamentales e intervenir intensamente en sus sistemas jurídicos, día tras día se están volviendo más increíbles. Al 
hacer esto, la Corte ha perjudicado una buena parte de la confianza de la que solía gozar. Por lo tanto, es simplemente lógico que el Tribunal Constitucional Federal de Alemania decidiese intervenir recientemente. Este último deberá proferir muy pronto un fallo que será de capital importancia para el desarrollo posterior de la jurisdicción europea, en tanto que tiene que ver con la pregunta de si la práctica jurídica excesiva de la CEJ debería, en el futuro, someterse nuevamente a controles más estrictos por parte del Tribunal Constitucional Federal de Alemania, o si, por el contrario, el Tribunal Constitucional Federal debería renunciar, de una buena vez, a su papel de organismo guardián. ${ }^{182}$

Aunque esta sombría predicción, que se formuló cuando escribieron este pasaje, no se ha producido, el debate de fondo se ha venido discutiendo. Lo que es más diciente de todo esto es el tono del mensaje que se emite desde el corazón mismo del establecimiento jurídico alemán.

De cualquier forma, en el caso Aranyosi la CEJ respondió al reto formulado desde Alemania. ${ }^{183}$ El fallo de la CEJ confirmó la relevancia de los principios de reconocimiento mutuo y confianza mutua entre los Estados miembros, pero aclaró que no son absolutos y pueden ceder "en casos excepcionales". ${ }^{184}$ Esta decisión confirió una mayor sensibilidad al desafío de la identidad. ${ }^{185}$ Para Mathias Hong, el fallo en Aranyosi supuso un cambio de tono y de postura respecto a Melloni. ${ }^{186}$ Este es un buen ejemplo de cómo a veces una resistencia fuerte (que constituyó, en efecto, una decisión de escape) puede eventualmente producir diálogo. La novedad de este diálogo es que la noción de identidad, constitucional o de cualquier otra clase, ahora forma parte del discurso. Ya no se trata únicamente de una discusión de derechos humanos o soberanía.

Todos los elementos de esta línea jurisprudencial pueden encontrarse en sentencias recientes emitidas por la Corte Suprema de Rusia. Este conjunto de decisiones ofrece un buen ejemplo del efecto opuesto del argumento identitario en el sentido en que los derechos humanos, como identidad, se convierten en una herramienta para proteger a la mayoría en lugar de al individuo. Esta serie de casos ilustra que la Corte de Rusia (como la polaca, la británica, la israelí, la italiana, la alemana y otras), se posiciona a sí misma como una instancia de apelación respecto de la aceptabilidad del razonamiento (más que como, estrictamente, una corte con una posición jerárquica superior) y también se sale de los cauces tradicionales para presentar, lo que es en esencia una decisión de escape desafiante, como una decisión dialógica.

182 R. Herzog y L. Gerken, "Stop the European Court of Justice”, EUobserver, en https://euobserver.com/opinion/26714.

183 Casos C-404/15 \& C-659/15 PPU, Aranyosi Căldăru, 2016 E.C.J. (Gran Sala) 198 (5 de abril de 2016) EU:C:2016:198.

184 Ibid., $\S \S 78,82$.

185 Ibid.

186 M. Hong, "Human dignity, identity review of the European arrest warrant and the Court of Justice as a listener in the dialogue of courts: Solange-III and Aranyosi: BVerfG 15 December 2015, 2 BvR 2735/14, Solange III, and ECJ (Grand Chamber) 5 April 2016, joined cases C-404/15 and C-659/15 PPU, Aranyosi and Căldăraru", en European Constitutional Law Review 12 (3) 2016, pp. 561-562. 
El contexto de una de dichas sentencias se relaciona con una reacción muy fuerte que se produjo en contra de las disposiciones de la Constitución de 1993 que parecían darle primacía al derecho internacional sobre el derecho doméstico. Esta fuerte reacción se desató, específicamente, a raíz del caso Yukos.

Debido a una petición formulada por 93 parlamentarios, la Corte Constitucional de Rusia examinó la constitucionalidad de la ley que ratificó la Convención Europea de Derechos Humanos. La Corte subrayó el principio de la supremacía de la Constitución en relación con los tratados internacionales y, aún más, resaltó el principio de supremacía constitucional frente a las interpretaciones posteriores de estos tratados que hicieren los órganos judiciales. A pesar de su proclamada determinación para evitar conflictos y promocionar el diálogo, la Corte mostró una clara disposición encaminada a controlar las interpretaciones evolutivas del Tribunal Europeo de Derechos Humanos, asumir el rol del árbitro final en materia de derechos humanos y priorizar la constitución doméstica y los equilibrios entre valores que ella establece. A continuación, se pueden leer algunas secciones claves de la decisión que hablan por sí mismas:

\begin{abstract}
Estando vinculada por el requisito de observar un tratado internacional que está en vigor -tal como el Convenio Europeo para la Protección de los Derechos Humanos y de las Libertades Fundamentales-, la Federación rusa, está, no obstante, obligada a asegurar la supremacía de la Constitución de la Federación rusa dentro del marco de su sistema jurídico. Aunque la Constitución de la Federación rusa y el Convenio Europeo para la Protección de los Derechos Humanos y de las Libertades Fundamentales se fundamentan en los mismos valores básicos de protección a los derechos humanos y civiles y a las libertades, en caso de colisiones en estas áreas, esta Corte está obligada a dar prevalencia a los postulados de la Constitución de la Federación rusa y, de este modo, no puede implementar literalmente los dictámenes del Tribunal Europeo de Derechos Humanos si es que esta implementación contradice los valores constitucionales. (Énfasis agregado)
\end{abstract}

Así, [...] si el Tribunal Europeo de Derechos Humanos, al interpretar una disposición del Convenio Europeo para la Protección de los Derechos Humanos y de las Libertades Fundamentales en el contexto de un caso le atribuye a un significado distinto al sentido ordinario o desarrolla una interpretación contraria al objeto y propósito del Convenio, el Estado respecto del cual se ha decidido el caso tiene el derecho a rehusarse a la ejecución del fallo dado que este excede las obligaciones voluntariamente asumidas por el Estado al ratificar el Convenio. ${ }^{187}$

En este caso encontramos también un juez de alto rango que se ha referido (extrajudicialmente) a la decisión, con el propósito de contextualizarla. Valery D. Zorkin, presidente de la Corte Constitucional de Rusia, señala: “El principal problema al que se ha enfrentado la Corte Constitucional de Rusia es la

187 Конституционный Суд Российской Федерации (Corte Constitucional de la Federación Rusa), Постановление Конституционного Суда РФ от 14.07.2015 N 21-П (Sentencia de la Corte Constitucional de la Federación Rusa del 14 de julio de 2015, número 21-П) . 
necesidad de cumplir simultáneamente con dos tareas que no son fáciles de combinar: por un lado, la armonización del sistema jurídico de Rusia con el extenso panorama jurídico de Europa y, por el otro, la protección de la propia identidad constitucional rusa". ${ }^{188}$

\section{Localización: la identidad como la voz de la tercera ola}

Identidad, entendida como tener una voz, es una forma atenuada de la jurisprudencia identitaria. En estos casos, las cortes no utilizan la "carta de la identidad" como un medio para evitar o exceptuarse de una norma internacional, sino como una forma de explicar un modo singular y específico por el cual se le da efecto a la norma internacional en el ámbito doméstico. En estos eventos, la voz se manifiesta a través de un proceso de localización. Decidimos agrupar este tipo de situaciones bajo la categoría identitaria debido a que la especificidad cultural y política de la jurisdicción respectiva ofrece el fundamento para el giro judicial nacional.

La sentencia de la Corte Suprema de la India en el caso Indira Sawhney v. Union of India, suministra un ejemplo de manual de esta localización en tanto que la Corte redefine la norma constitucional de igualdad en términos locales. ${ }^{189}$

Este caso tuvo que ver con la constitucionalidad de ciertas medidas de acción afirmativa que establecieron un número de cupos en cargos del gobierno para los miembros de las "clases desaventajadas". El fallo introdujo la noción de una "capa intermedia" dentro de las clases desaventajadas, noción que se refería a aquellos miembros de la clase desaventajada que están relativamente bien y que, por ello, no deberían beneficiarse de la acción afirmativa. Esta sentencia también es importante porque destaca la importancia específica de una noción sustantiva de igualdad en el sistema constitucional de la India y que se distingue de otras variedades de igualdad que se pueden hallar en otros sistemas constitucionales -como en Estados Unidos- y que son menos receptivas a la idea de acciones afirmativas. Esta distinción se construyó sobre la base de las singularidades de la historia constitucional, el contexto social, los valores locales (de estirpe hindú) y la redacción de la Constitución india. El siguiente extracto es una muestra del lenguaje que usó la Corte:

2. La Asamblea Constituyente, a pesar de que fue elegida mediante voto limitado, fue un órgano representativo de todos los sectores de la sociedad. Antes que nada, estuvo compuesta por hombres con visión, conscientes de la histórica pero compleja tarea de moldear una sociedad igualitaria a partir de una impresionante variedad de religiones, comunidades, castas, razas, idiomas, creencias y prácticas. Estas personas

188 E. Zendeli, "The challenges of the implementation of paragraph 1 of article 6 of the European Convention on Human Rights and Fundamental Freedoms in the Judicial System of the Republic of Macedonia", en Journal of Politics and Law 6 (2) (2013), pp. 1-2.

Indra Sawhney Etc. Etc vs Union of India and Others, Etc - AIR 1993 SC 477, 1992 Supp 2 SCR 454, 1992. 
conocían su país a profundidad. Entendieron perfectamente su sociedad. Estaban al tanto de las injusticias y desigualdades históricas que afligían a la sociedad. Se dieron cuenta del imperativo que era corregirlas por medios constitucionales, tan pronto como fuere posible. La alternativa era aterradora. Ellos tomaron nota de la ignorancia, el analfabetismo y, sobre todo, la pobreza descomunal. Eran conscientes del hecho de que la religión hindú -la religión de la inmensa mayoría- tal y como se practicaba, no reflejaba un ethos igualitario. Era una religión que dividía a sus feligreses en cuatro compartimientos aislados. Aquellas personas que estuvieran por fuera de este sistema de cuatro grupos (chaturvarnya) eran parias (panchamas), lo más bajo de la escala social. El cuarto grupo, shudras, no estaban en una situación mucho mejor que la de los panchamas, pero ciertamente estaban en una mejor posición. La posición de inferioridad se les asignaba a los shudras y panchamas en virtud de su nacimiento en estas castas, esto es, sin reparar en sus acciones. No existía ninguna esperanza de que estas personas se liberasen de este estigma social (excepto, tal vez, por medio de la muerte). Estaban condenadas a ser inferiores. Todas las ocupaciones insignificantes, bajas o desagradables, se les asignaba a estas personas. En la vida rural, ellas no tenían otro remedio sino hacerse cargo de estos oficios, generación tras generación, siglo tras siglo. Se les decía que ese era su "karma", la sanción por los pecados que ellas, presuntamente, habían cometido en su vida pasada. Lo más triste es que ellas creían todo esto. Se les condicionaba para que lo creyeran. Esta venda mental debía removerse primero. Era un fenómeno peculiar de este país. Siempre ha habido (y hay) pobreza en todos los países. Pero ninguno de ellos sufría la desgracia de tener esta división social -o, como algunos la llaman, degradación- junto con la pobreza. La pobreza, la pertenencia a una clase social baja en el sistema de castas hindú y la ocupación tan baja que debían desempeñar, daban lugar (y aún dan lugar) un círculo vicioso. Los padres fundadores estaban al tanto de todo esto. $Y$ de más.

Luego de esto la Corte examina, de una forma ejemplar, nociones internacionales y comparadas de igualdad y delinea la propia concepción (admirable) de la India en este contexto. Otro ejemplo de este proceso de localización en el área del secularismo se encuentra en la decisión del caso Bommai. ${ }^{190}$

La experiencia de India refleja la existencia de ciertas sensibilidades identitarias presentes en los primeros años de esa nación. En realidad, esta no es una forma revolucionaria de razonamiento por parte de cortes constitucionales. Sin embargo, como el siguiente conjunto de ejemplos parece sugerir, estas sensibilidades son mucho más acentuadas hoy en día. Hong Kong ofrece una inflexión en el uso de la identidad en la jurisprudencia constitucional. Mientras que la cultura local se usa normalmente como el telón de fondo ante el cual se define un argumento identitario para oponerlo a las normas transnacionales, en Hong Kong (con la continua y cada vez más compleja "guerra de desgaste entre Beijing y Hong Kong") los roles se han invertido y ha sido la normatividad internacional la que se ha integrado a la especificidad de la identidad de Hong Kong como bastión contra la presión desde el continente. 
La Ley Fundamental de Hong Kong les permite explícitamente a las cortes aludir a "otras jurisdicciones de common law" (art. 84) e incorpora el Pacto Internacional de Derechos Civiles y Políticos (PIDCP), el Pacto Internacional de Derechos Sociales, Económicos y Culturales (Pidesc) y los convenios internacionales del trabajo a su sistema constitucional (art. 39). Todo esto, junto con los lazos históricos que existen con el sistema jurídico británico, hacen que la Corte de Apelación Final de Hong Kong (la instancia judicial de mayor jerarquía) esté extraordinariamente abierta al derecho extranjero e internacional, y que la mayoría de las citas en sus decisiones sea a sentencias judiciales no domésticas. No obstante, y debido al estatus de autonomía específico de Hong Kong en relación con China, la Corte de Apelación Final de Hong Kong ha reafirmado las especificidades propias de su sistema frente al sistema jurídico chino (basado en el derecho continental) gracias a sus referencias a su herencia desde el common law y al uso que ha hecho del derecho internacional y comparado. ${ }^{191}$

Por otro lado, la identidad sexual y asuntos relacionados con ella son un terreno fértil para la producción de una jurisprudencia conflictiva y no son, de ningún modo, temas nuevos. Sin embargo, algo que se debe anotar sobre alguna jurisprudencia reciente acerca de esta materia es el uso cada vez mayor de conceptos, vocabulario o sensibilidades identitarias en los argumentos que fundamentan las tesis de las cortes constitucionales. Se debe anotar, en todo caso, que a pesar de que Kenji Yoshino y Michel Kavey reseñan el movimiento global hacia el reconocimiento de las uniones entre personas del mismo sexo, también resaltan que la mayoría de eventos en los que existe dicho reconocimiento, este se ha dado por cuenta de decisiones legislativas y muchas veces sin necesidad de intervención judicial directa. ${ }^{192} \mathrm{~A}$ continuación se podrán ver algunos ejemplos de casos en los que la identidad constitucional o nacional forman parte explícita o implícita de los argumentos centrales de las cortes en este campo del derecho. En una sentencia enfocada en el asunto del matrimonio entre personas del mismo sexo, el Tribunal Constitucional Polaco recalcó que la concepción específica de matrimonio y la forma de discriminación particular fundada en la orientación sexual eran temas que no podían modificarse por cuenta del derecho internacional. ${ }^{193}$ De manera semejante, el Tribunal Constitucional de Chile decidió, con base en un motivo identitario

191 Xianggang Zhongshenfayuan (Corte de Apelaciones Finales de Hong Kong), Director of Immigration v. Chong Fung Yuen - 香港終審法院 (Xianggang Zhongshenfayuan) (Corte de Apelaciones Finales de Hong Kong) - H.K.C.F.A. 48; [2001] 2 H.K.L.R.D. 533; (2001) 4 H.K.C.F.A.R. 211; FACV 26/2000, 2001; Ng Ka Ling and Another v. Director of Immigration - 香港終審法院 [1999] H.K.C.F.A. 72; [1999] 1 H.K.L.R.D. 315; (1999) 2 H.K.C.F.A.R. 4; [1999] 1 H.K.C. 291; FACV 14/1998, 1999.

192 K. Yoshino y M. Kavey, "Immodest claims and modest contributions: Sexual orientation in comparative Constitutional Law", en M. Rosenfeld y A. Sajó (eds.), The Oxford Handbook of Comparative Constitutional Law, , Oxford, Oxford University Press, 2012, pp. 1090-1091.

193 Trybunał Konstytucyjny (Tribunal Constitucional de Polonia), Wyrok, Trybunału Konstytucyjnego, z dnia 11 maja 2005 r. (Constitutionality of the Accession Treaty) K 18/04. 
parecido, no reconocer el matrimonio entre personas del mismo sexo a la luz de la tradición jurídica chilena. ${ }^{194}$

Por su parte, la Corte de Apelación Final de Hong Kong examinó la solicitud de una mujer transexual para poderse casar y subrayó su papel como catalizador de las convenciones sociales en Hong Kong. La Corte destacó que, para efectos de la elaborar cualquier interpretación judicial, "la consideración principal deben ser las circunstancias de Hong Kong, de la misma manera en la que el TEDH se ha preocupado por las situaciones al interior de los Estados miembros". ${ }^{195}$ De este modo, la Corte concluyó que "no existe ninguna evidencia de que las actitudes sociales en Hong Kong hacia el concepto tradicional de matrimonio y la institución del matrimonio se hayan alterado de manera fundamental" ${ }^{196}$

La atención que se ha prestado a las consideraciones identitarias en algunos casos de Corea del Sur también ha sido evidente. La Corte surcoreana construyó su razonamiento identitario sobre la tradición local y sobre preocupaciones singulares de seguridad nacional en algunos casos, como aquellos que estudiaron la constitucionalidad de la pena de prisión (como única pena posible) para el delito de adulterio o fornicación con persona casada, ${ }^{197}$ la constitucionalidad de la pena de muerte ${ }^{198}$ y la posibilidad de ser objetor de conciencia de cara a la obligación de prestar servicio militar. ${ }^{199}$ La Corte afirmó que "la idea de castidad inherente a la sociedad coreana, en particular entre esposo y esposa, es un aspecto ético tradicional heredado y que aún se encuentra enraizado en la sociedad". ${ }^{200}$ Así mismo, la Corte se abstuvo de decidir sobre la constitucionalidad de la pena capital, pero exhortó al legislador para que "no ahorrase esfuerzos dirigidos a corregir los problemas generales de las reglas que rigen la pena de muerte (y que se basan en un consenso nacional), con el fin de hacer frente a los cambios que han traído los tiempos y derogar las normas o artículos que sean necesarios" ${ }^{201}$ Por último, la Corte de Corea del Sur realzó las circunstancias de seguridad singulares que vive el país con el propósito de justificar su posición sobre la objeción de conciencia al servicio militar:

194 Tribunal Constitucional de Chile, Procedimiento: Requerimiento de inaplicabilidad por inconstitucionalidad. Causa: 1881-10, 2011.

195 Xianggang Zhongshenfayuan (Corte de Apelaciones Finales de Hong Kong), W v Registrar of Marriages - 香 港終審法院 [2013] HKCFA 39; FACV 4/2012, 2013, párr. 187.

196 Ibid., párrs. 187-188.

197 Heonbeop Jaepanso (Corte Constitucional de Corea del Sur), 20-2(A) KCCR 696 (Caso del Adulterio) -헌법재 판소, 2007 Hun-Ka17·21; 2008 Hun-Ka7·26; 2008 Hun-Ba21·47.

198 Heonbeop Jaepanso (Corte Constitucional de Corea del Sur), 22-1(A) KCCR 36 (Caso de la Pena de Muerte) 헌법재판소, 2008Hun-Ka23. 22-1(A).

199 Heonbeop Jaepanso (Corte Constitucional de Corea del Sur), 16-2(A) KCCR 141 (Caso de la Objeción de Conciencia para Servicio Militar) - 헌법재판소, 2002Hun-Ka1.

312200 Heonbeop Jaepanso (Corte Constitucional de Corea del Sur), 20-2(A) KCCR 696 (Caso del Adulterio) -헌 법재 판소, 2007 Hun-Ka17·21; 2008 Hun-Ka7·26; 2008 Hun-Ba21·47.

201 Heonbeop Jaepanso (Corte Constitucional de Corea del Sur), 16-2(A) KCCR 141 (Caso de la Objeción de Conciencia para Servicio Militar) - 헌법재판소, 2002Hun-Ka1. 
En nuestra sociedad, en donde el imperativo social de distribuir por igual la carga del servicio militar es robusto y absoluto, [...] la adopción de un sistema que prevea un servicio alternativo puede causar un daño muy serio a la capacidad de la nación (como un todo), al afectar significativamente la unidad social. Igualmente, podría desestabilizar la columna vertebral del sistema de servicio militar que se funda en el reclutamiento obligatorio de todos los ciudadanos. ${ }^{202}$

En cada una de estas sentencias, la Corte coreana señaló cómo y por qué su razonamiento era incompatible con la jurisprudencia constitucional comparada emitida por otras cortes. En el contexto de la prisión por adulterio, expresó que

... es muy difícil sostener que un cambio en las relaciones jurídicas del derecho de familia hará que el adulterio no sea un elemento perturbador para los estándares sociales normales y que, por ello, debiera desaparecer la necesidad de un castigo penal, a pesar de la tendencia legislativa global de no castigar a los adúlteros y fornicadores $\mathrm{y}$ del hecho de que el adulterio puede ser un motivo suficiente para el divorcio y el pago de compensación por daños morales. Esto también se debe a que factores como la situación de los tiempos que corren, los valores de las personas en relación con la sexualidad y la existencia de un derecho de familia cimentado sobre la igualdad varía intensamente entre los diferentes países.

En esa misma línea, la Corte de Corea del Sur aseguró que "el deber de prestar servicio militar y el principio de igualdad como guía para asignar la carga del servicio militar, tienen un significado relevante y propio en el país, significado que no se puede comparar con el que le asignan otras naciones" ${ }^{203}$ En el caso de la pena de muerte, la Corte adoptó un estándar menos deferente e instruyó al legislador para que

... continuara con el esfuerzo de consultar las experiencias de otros países que, aunque conservan la pena de muerte, han mejorado sus sistemas penales al reducir el número de delitos que acarrearían dicha sanción (por ser contraria, en esos casos, a los principios del sistema penal) y al remover, tanto como sea posible, las causas que dan origen a los problemas que supone la imposición de la pena capital. ${ }^{204}$

\section{Michel Rosenfeld ${ }^{205}$ ha observado cómo}

... una comunidad constitucional imaginada debe constantemente luchar para diferenciarse a sí misma de su correspondiente comunidad nacional imaginada (sin, al mismo tiempo, cortar los lazos que tiene con esta última) al punto que las dos no pueden ser ya imaginadas desde una perspectiva más comprehensiva como indicadores de una misma identidad y una correspondiente individualidad que, a su vez, vinculase un pueblo a su nación, así como a su Constitución. ${ }^{206}$

205 M. Rosenfeld, The identity of the constitutional subject: selfhood, citizenship, culture, and community, London, Routledge, 2009. 
La jurisprudencia contemporánea de las cortes constitucionales refleja esta tensión concreta en aquellos eventos en los que los jueces tratan de replantear y expresar las sensibilidades nacionales en términos constitucionales.

El conflicto que examinamos en la sección anterior entre cortes domésticas e internacionales relativo a los derechos de los reclusos, la inmunidad y la seguridad a lo largo de las fronteras, traduce las cuestiones de identidad nacional a un lenguaje jurídico. Es complejo decir si las cortes en algunos de estos casos, al trasladar sensibilidades nacionalistas e identitarias al lenguaje de lo jurídico, reaccionan a o reflejan el trasfondo de una era de marcada resistencia a las cortes. Aunque la noción de identidad existió en la jurisprudencia constitucional antes del Brexit, con mucha cautela nos atrevemos a sugerir que la jurisprudencia producida en la era del Brexit (brevemente estudiada en este artículo) ofrece ejemplos en los cuales las cortes se involucraron en sus decisiones con la cuestión de la identidad de una forma más frontal. El ascenso de estas sensibilidades "ahora" se ha facilitado debido a la presencia de factores propios de cada contexto constitucional aunada a otros sucesos globales como la crisis económica de 2008, la crisis de los refugiados y otras dinámicas geopolíticas de poder. Nuestra modesta contribución en este escrito es simplemente sugerir que si la primera ola del control de constitucionalidad produjo una concepción atomizada del individuo y los sucesos de la segunda ola profundizaron la perspectiva reduccionista sobre esta individualidad y la experiencia humana, entonces no es sorpresivo que este efecto acumulado haya llevado a las cortes constitucionales a resistirse a las fuentes normativas cosmopolitas e internacionales y a privilegiar un tipo de razonamiento constitucional que subraya los valores e identidad locales. La perspectiva de las olas puede suministrar un lente adicional o complementario por el cual se pueda explicar el uso y la resonancia de esas sensibilidades de la identidad. Estos desarrollos son compatibles, también, con el énfasis que hicimos sobre la existencia de un movimiento dialéctico al interior y entre las olas. La pregunta es hasta qué punto las reivindicaciones de identidad indican un quiebre frente a la tendencia de la internacionalización del derecho constitucional. Después de todo, este tipo de reivindicaciones han estado siempre presentes de una manera u otra. Nuestro hallazgo es más bien anecdótico, pero, aun así, detectamos un giro más pronunciado hacia la identidad. En otros términos, si bien las cortes en el pasado pueden haberse inspirado en las especificidades y tradiciones constitucionales, el giro hacia la identidad ahora puede ser una consecuencia del impacto del derecho internacional en el derecho constitucional o de un intento por neutralizar o contener las resistencias intensas hacia el judicial. Todo esto ha llevado a las cortes a justificar abiertamente su desviación frente al derecho internacional o a construir sus argumentos en términos de identidad. Esta jurisprudencia se desarrolla y se escribe a la sombra de un escape à la Brexit. 


\section{Conclusión - La tragedia del control de constitucionalidad en el mundo contemporáneo}

Mauro Cappelletti fue, él mismo, una creatura del periodo que exploró. Fue un ferviente antinazi en su adolescencia y vivió los sucesos de la posguerra que, para él, no solo constituyeron un punto de quiebre en la historia de la justicia y el Estado de derecho, sino que consideraba deseables. Como tantos idealistas de esa generación, aborreció cualquier tipo de tiranía, albergó un profundo escepticismo sobre la idea de un Estado-nación europeo y experimentó una profunda crisis de fe en la rectitud de las instituciones popularmente democráticas. Por ello, puso sobre un pedestal su fe en, por un lado, los arreglos "internacionales" y federales (que servirían de contrapeso a los atavismos locales) y, por el otro, en judicaturas poderosas (que eran indispensables para lograr una buena gobernanza). Admiró a Estados Unidos, pero también lo rechazó en un aspecto: la notoria aversión de su poder judicial frente a las normas internacionales que, para él, eran un parámetro indispensable del paradigma democrático. No es sorpresivo, entonces, que su cartografía del control judicial en el mundo contemporáneo se entrelazara con su historiografía implícita; una historia de un proceso lineal y mundial impulsado por un único motor normativo: ¡el progreso! No se debe reducir ni un ápice la magnitud de los notables logros académicos y visionarios de Cappelletti: el control judicial, de naturaleza constitucional, se ha convertido en la regla (más que en la excepción) en el mundo contemporáneo, una predicción que no era autoevidente cuando se formuló.

Como era de esperarse, luego de repasar la cartografía y la historiografía de Cappelletti, nuestro análisis procuró hacer algo más que simplemente añadir una montaña aquí o un valle más allá y algo más que cartografiar las partes del mundo que no fueron consideradas en su audaz exploración. Nuestra cartografía e historiografía, que se produce cincuenta años después, cuenta de manera comprensible una historia en muchos sentidos diferente. Una historia en la que lo dialéctico reemplaza a lo lineal, en la que el uso de nuestra metáfora de las "olas" hace que las causalidades que explican este proceso general sean más complejas y se muevan dentro de las olas y entre ellas y, por último, pero muy importante, en la que la normatividad es, en el sentido estricto del término, a menudo trágica y el resultado de contradicciones inconmensurables e incluso necesarias.

Esto es así porque, como no había sucedido antes, el intrincado mapa del control judicial refracta una realidad compleja en la que la noción misma de lo "público" (y el espacio público) ha cambiado. Como no había sucedido antes, ahora somos parte de un espacio local (que a veces no es siquiera espacial), 
un espacio nacional (que aún es muy fuerte en el mundo) y un espacio global y transnacional. Lo queramos o no, ahora poseemos múltiples pasaportes (a pesar de que algunos de nosotros quisiéramos quemar uno u otro).

Los modos de regulación internacional, que se refuerzan por un cada vez más amplio y profundo abanico de mecanismos de cumplimiento, se han transformado en una verdadera forma de gobernanza que ha reemplazado no solo o preponderantemente el rol de los parlamentos, sino, con un mayor impacto, también el rol de las administraciones nacionales. Hemos sugerido que el concepto de "gobernanza internacional" ya no es una cuestión de elección: hay muchísimos fenómenos que, simplemente, trascienden el poder práctico de control y regulación que tienen y que pueden ejercer incluso los Estados más poderosos por sí mismos. También observamos que el declive en la mayoría de las sociedades de la oposición basada en principios al control judicial -entendido ahora como una parte y parcela de la democracia y la buena gobernanza-no suprime ciertas opiniones fuertes sobre algunas de sus manifestaciones específicas que se han producido en esta y otras eras o constelaciones políticas.

El surgimiento de la tercera ola puede interpretarse como una corrección automática del propio sistema. Se trata de un fenómeno interesante que algunos "puristas" internacionales consideran como aberrante. Para nosotros, es algo inevitable, también, desde una perspectiva normativa. ¿Por qué?

En la medida en que el vocabulario y la ontología de la democracia encuentran sus raíces en las nociones de demos, nación y Estado, no existe una simple plantilla conceptual internacional en el inventario tradicional de teorías democráticas que pueda emplearse para cerrar la brecha democrática en la gobernanza internacional. Una aplicación simplista de la regla de la mayoría en las arenas mundiales sería prácticamente absurda: un demos del mundo existe solamente en la utopía/distopía de ciencia ficción en Star Wars. No se trata de adaptar las instituciones y los procesos nacionales a los contextos internacionales. Esto podría funcionar solo en circunstancias restringidas. Lo que se requiere es tanto un replanteamiento de las mismas bases de la democracia para ver cómo pueden (o no) emplearse en un sistema internacional que no es ni Estado ni nación, así como una búsqueda de artefactos legitimadores alternativos que puedan compensar la inaplicabilidad de algunas de las instituciones de la democracia en aquellos eventos en los que no es posible hacerlo. Si se quiere que el Estado de derecho permanezca como uno de los pilares esenciales de la democracia pluralista, la tercera ola no solo es inevitable, sino que si se desarrolla prudente y juiciosamente (si los jueces nacionales comprenden qué significa sacarse su "camiseta" nacional y actuar en nombre del espacio global), puede concebirse como algo necesario y deseable.

Cuando aludimos en este escrito a la tragedia de este nuevo espacio público, a menudo lo hacemos de una forma desligada de los sentimientos. Asumi- 
mos que los desarrollos que se reflejan en la primera ola aún podrían suponer una carga muy pesada sobre los jueces cuya consciencia jurídica les exige dejar sin efectos decisiones mayoritarias. Respecto de la segunda ola, y desde nuestro propio sistema de valores, estimamos que gran parte de la ampliación y profundización del derecho internacional a lo largo del último siglo (especialmente en las últimas décadas en las que estos procesos se han acelerado) ha beneficiado a la humanidad y ha hecho al mundo un mejor lugar para vivir para un número considerable de personas. ${ }^{207}$ También creemos que, como ocurre en ciertas situaciones domésticas en donde el Estado de derecho es un elemento necesario y una condición para la debida operación de una democracia, lo mismo, mutatis mutandis, podría predicarse del sistema internacional. Desde esa perspectiva, un llamado al desmantelamiento total de los regímenes jurídicos internacionales sería algo regresivo. Y aun así, es evidente que una buena parte del proceso de fijación de normas internacionales (particularmente en el área del derecho administrativo global) carece de los elementos básicos de lo que consideramos como legitimidad democrática y, aunque usualmente está influenciado por actores de buena fe, muchas otras veces ha sido capturado por intereses particulares económicos típicamente muy poderosos de los cuales el individuo es excluido. Los casos que mencionamos como precursores de la tercera ola ilustran todo esto. Consideramos también que, en la esfera internacional (por el momento) y como ocurre en otros espacios, el fin justifica los medios, pero creemos, asimismo, que una legitimidad fuertemente sesgada hacia la consecución de resultados y alejada del proceso (basada en outputs y, solo limitadamente en inputs) es una legitimidad muy débil y, a veces, inexistente.

Ahora, en el terreno de los sentimientos, el primero de ellos sería un llamado a los Estados, a sus órganos internos (especialmente las cortes) y a otros actores, para que acojan la normatividad internacional. El segundo sentimiento sería un llamado a estos mismos agentes para que traten la normatividad internacional con cautela considerable. La oposición tradicional al "internacionalismo" provino del nacionalismo y fue conceptualizada como una tensión entre la soberanía nacional y el derecho internacional. La oposición a la que nos referimos no tiene que ver, en cambio, con soberanía (al menos no con la soberanía clásica del Estado). La oposición a la que aludimos considera el orden jurídico internacional como un acquis, pero no está dispuesta a celebrar los beneficios de este acquis cuando ellos se han obtenido mediante la privación de los derechos democráticos del pueblo y de los pueblos. En este sentido, existe una paradoja profunda en la expansión de las democracias liberales a un número cada vez mayor de Estados y poblaciones alrededor del mundo. La

207 Se debe, por supuesto, matizar esta afirmación. Hay muchos regímenes internacionales (especialmente en el campo económico) que ignoran, comprometen o incluso perjudican los intereses y las reivindicaciones de justicia de muchas personas y grupos. La justicia universal, como sea que se la defina, es aún una aspiración lejana. 
expansión de la segunda ola es, de este modo, inherentemente problemática desde un punto de vista normativo.

Desde una perspectiva optimista, el surgimiento gradual de la tercera ola se entrelazará de un modo tal que producirá un patrón de pesos y contrapesos que podría morigerar algunos de los problemas del internacionalismo acentuado y, poco a poco, hará que el orden jurídico internacional encuentre las formas para traducir los hábitos y las prácticas de la democracia doméstica en la esfera internacional. Pero incluso esta visión optimista no está exenta de una naturaleza trágica. Volviendo a los primeros párrafos de este escrito, todo el proceso que hemos descrito, bien sea en su forma newtoniana Cappellettiesca o en nuestra propia versión einsteiniana más compleja, tiene una constante, un leitmotiv: las cortes, internacionales y domésticas, reaccionan contra las tiranías (reales o supuestas) en representación de sus víctimas individuales. En el nuevo espacio público que hemos descrito -incluso en su manifestación global- las cortes han ubicado al individuo en el centro de su actividad judicial como nunca antes había ocurrido en la historia. Aunque la identidad y las preocupaciones sobre el Estado de derecho y la democracia han ganado terreno en la jurisprudencia constitucional contemporánea, el compromiso republicano o las preocupaciones sobre desigualdad y justicia distributiva continúan siendo marginalizados. Y en este punto, también, lo trágico se hace presente para quienes quieran verlo: un mundo en el que el individuo, ubicado en el centro de todo, cada vez más se vuelve un individuo centrado en sí mismo, en perjuicio de lo social.

\section{Bibliografía}

Ackerman, B., "The rise of world constitutionalism", en Virginia Law Review 83 (4) (1997), pp. 771-797, en https://doi.org/10.2307/1073748.

AJIL Unbound, Symposium on the Constitutionalization of International Law in Latin America, 2015, en http://www.iconnectblog.com/2015/11/symposiumon-the-constitutionalization-of-international-law-in-latin-america.

Alter, K. J., Establishing the supremacy of European law: The making of an international rule of law in Europe, Oxford, Oxford University Press, 2010.

Alviar Garcia, H., "Looking beyond the constitution: The social and ecological function of property", en Comparative Constitutional Law in Latin America, Cheltenham, Edward Elgar Publishing, 2017.

Arato, J., "A preemptive strike against European Federalism: The decision of the Bundesverfassungsgericht concerning the treaty of Lisbon" [blog], EJIL Unbound, 2010. https://www.ejiltalk.org/a-preemptive-strike-aga- 
inst-european-federalism-the-decision-of-the-bundesverfassungsgerichtconcerning-the-treaty-of-lisbon/.

Aust, H. P., Rodiles, A. y Staubach, P., “Unity or uniformity? Domestic courts and treaty interpretation", en Leiden Journal of International Law 27 (1) (2014), pp. 75-112, en https://doi.org/10.1017/S0922156513000654

Battini, S., "The procedural side of legal globalization: The case of the World Heritage Convention", en International Journal of Constitutional Law 9 (2) (2011), pp. 340-368, en https://doi.org/10.1093/icon/mor033

Beatson, J., Grosz, S., Hickman, T., Palmer, S. y Singh, R., Human Rights: Judicial Protection in the United Kingdom, London, Sweet \& Maxwell, 2008.

Benvenisti, E., "Judicial misgivings regarding the application of International Law: An analysis of attitudes of National Courts", en European Journal of International Law 4 (1993), P. 159, en https://doi.org/10.1093/oxfordjournals. ejil.a035824

Benvenisti, E., "Reclaiming democracy: The strategic uses of foreign and international law by national courts", American Journal of International Law 102 (2) (2008), pp. 241-274, en https://doi.org/10.2307/30034538

Benvenisti, E. y Downs, G. W., Between Fragmentation and Democracy: The Role of National and International Courts, Cambridge, Cambridge University Press, 2017, en https://doi.org/10.1017/9781108236607

Benvenisti, E. y Downs, G. W., "National courts, domestic democracy, and the evolution of international law", en European Journal of International Law 20 (1) (2009), pp. 59-72, en https://doi.org/10.1093/ejil/chp004

Benvenisti, E. y Downs, G. W., “The empire's new clothes: political economy and the fragmentation of international law", Stanford Law Review, 60 (2007), p. 595.

Benvensiti, E. y Downs, G. W., “Democratizing courts: How national and international courts promote democracy in an era of global governance", NYU Journal of International Law \& Politics 46 (2013), p. 741.

Bickel, A. M., The least dangerous branch, New Haven, Yale University Press, 1986.

Bilder, M. S., "The corporate origins of judicial review", Yale Law Journal 116 (2006), pp. 503-567.

Blokker, P. et al., "Constitution making in Romania: From reiterative crises to Constitutional moment", en Revista Română de Drept Comparat 02 (2012), pp. 187-204, en https://doi.org/10.2139/ssrn.2290143

Bogdandy, A., “Guest Editorial: Let's hunt zombies”, ESIL Newsletter. 
Bogdandy, A., Wolfrum, R., Bernstorff, J., Dann, P. y Goldmann, M., “The exercise of public authority by international institutions: advancing international institutional law", Springer Science $\mathcal{E}$ Business Media 210 (2010).

Brzezinski, M. F. y Garlicki, L., “Judicial review in post-communist Poland: The emergence of a Rechtsstaat", en Stanford Journal of International Law 31 (1995), p. 13.

Bushnell, D. y MacAulay, N., The Emergence of Latin America in the Nineteenth Century, 2 ed., New York, Oxford University Press, 1994.

Cane, P. (ed.), "Administrative interpretation", en Controlling Administrative Power: An Historical Comparison, Cambridge, Cambridge University Press, 2016, pp. 203-237, en https://doi.org/10.1017/CBO9781316550878.007

Cappelletti, M., "Judicial review in comparative perspective", California Law Review 58, (5) (1970), pp. 1017-1053, en https://doi.org/10.2307/3479676

Cappelletti, M., Judicial Review in the Contemporary World, Indianapolis, BobbsMerrill, 1971.

Cappelletti, M., The Judicial Process in Comparative Perspective, Oxford, Oxford University Press, 1989.

Cappelletti, M. y Garth, B., "Access to justice and the welfare state: An introduction", en M. Cappelletti (ed.), Access to Justice and the Welfare State, Fiesole, European University Institute, 1981, pp. 1-24.

Chang, W. C. y Yeh, J. R., "Internationalization of Constitutional Law”, en M. Rosenfeld y A. Sajó (eds.), The Oxford Handbook of Comparative Constitutional Law, Oxford,Oxford University Press, 2012, en https://doi.org/10.1093/ oxfordhb/9780199578610.013.0058

Choudhry, S., "Bridging comparative politics and comparative constitutional law: Constitutional design in divided societies", en S. Choudhry (ed.), Constitutional Design for Divided Societies: Integration or Accommodation?, Oxford, Oxford University Press, 2008, pp. 3-40.

Choudhry, S., "Globalization in search of justification: Toward a theory of comparative constitutional interpretation", en Ind. Lj 74 (1998), p. 819.

Chu, J., "Global constitutionalism and judicial activism in Taiwan", en Journal of Contemporary Asia 38 (4) (2008), pp. 515-534, en https://doi. org/10.1080/00472330802309377

320 Clayton, R. y Tomlinson, H., The Law of Human Rights, 2 ed., Oxford, Oxford University Press, 2009. 
Couso, J., "The 'economic constitutions' of Latin America: Between free markets and socioeconomic rights", en Comparative Constitutional Law in Latin America, Cheltenham, Edward Elgar Publishing, 2017.

Crenshaw, K. W., "Race, reform, and retrenchment: Transformation and legitimation in antidiscrimination law", en Harvard Law Review 101 (1987), p. 1331, en https://doi.org/10.2307/1341398

Dahl, R. A., "Decision-making in a democracy: The Supreme Court as a national policy-maker", en Emory Law Journal 50 (2) (2001), p. 563.

De Búrca, G., "The European Court of Justice and the international legal order after Kadi", en Harv. Int'l LJ 51 (2010), p. 1.

Deener, D., "Judicial review in modern constitutional systems", en The American Political Science Review 46 (4) (1952), pp. 1079-1099, en https://doi. org/10.2307/1952114

Delgado, R., "The ethereal scholar: Does critical legal studies have what minorities want", en Harvard Civil Rights-Civil Liberties Law Review 22 (1987), p. 301.

Dickson, B., Human Rights in the UK Supreme Court, Oxford, Oxford University Press, 2013, en https://doi.org/10.1093/acprof:oso/9780199697458.001.0001

Dixon, R. y Posner, E. A., "The limits of constitutional convergence”, en Chinese Journal of International Law 11 (2010), pp.399-424, en https://doi.org/10.2139/ ssrn.1677634

Duranti, M., The Conservative Human Rights Revolution: European Identity, Transnational Politics, and the Origins of the European Convention, New York, Oxford University Press, 2017, https://doi.org/10.1093/acprof:o so/9780199811380.001.0001

Egger, P. y Merlo, V., "BITs bite: An anatomy of the impact of bilateral investment treaties on multinational firms", The Scandinavian Journal of Economics 114 (4) (2012), pp. 1240-1266, https://doi.org/10.1111/j.14679442.2012.01729.x

Elkins, Z. y Simmons, B., "On waves, clusters, and diffusion: A conceptual framework", en The Annals of the American Academy of Political and Social Science 598 (1) (2005), pp. 33-51, en https://doi.org/10.1177/0002716204272516

Elster, J., "Forces and mechanisms in the constitution-making process", en Duke Law Journal 45 (1995), p. 364, https://doi.org/10.2307/1372906

Ely, J. H., Democracy and distrust: A theory of judicial review, Cambridge MA,

Harvard University Press, 1980, en https://doi.org/10.2307/j.ctv102bj77 
Evans, P., Jacobson, H. K. y Putnam, R. D. (eds.), Double-Edged Diplomacy: International Bargaining and Domestic Politics, Berkley, University of California University Press, 1993, en https://doi.org/10.1525/9780520912106

Falk, R. A., "The role of domestic courts in the international legal order", en Indiana Law Journal 39 (1963), pp. 429-445.

Fallon, R. H. Jr., "The core of an uneasy case for judicial review”, en Harvard Law Review 121 (7) (2007), pp. 1693-1736.

Fassbender, B., "The United Nations Charter as Constitution of the International Community", en Columbia Journal of Transnational Law 36 (3) (1998), pp. 529-619.

Fastenrath, U., Geiger, R., Khan, D. E., Paulus, A., von Schorlemer, S. y Vedder, C. (eds.), From Bilateralism to Community Interest: Essays in Honour of Bruno Simma, Oxford, Oxford University Press, 2011, en https://doi.org/10.1093/ acprof:oso/9780199588817.001.0001

Favoreu, L., "Constitutional review in europe", en L. Henkin y A. Rosenthal (eds.), Constitutionalism and Rights: The Influence of the United States Constitution Abroad, New York, Columbia University Press, 1989.

Ferejohn, J., "Judicializing politics, politicizing law", en Law and Contemporary Problems 65 (3) (2002), pp. 41-68, en https://doi.org/10.2307/1192402

Ferejohn, J. y Pasquino, P., “Constitutional adjudication: Lessons from Europe", en Texas Law Review 82 (2003), p. 1671.

Foster, S., "Reluctantly restoring rights: Responding to the prisoner's right to vote", en Human Rights Law Review 9 (3) (2009), pp. 489-507, en https://doi. org/10.1093/hrlr/ngp017

Franck, T. M., "Legitimacy in the international system”, en American Journal of International Law 82 (4) (1988), pp. 705-759, en https://doi.org/10.2307/2203510

Gabel, P., "Phenomenology of rights-consciousness and the pact of the withdrawn selves", en Texas Law Review 62 (1983), p. 1563.

Gardbaum, S., "Are strong constitutional courts always a good thing for new democracies", en Columbia Journal of Transnational Law 53 (2014), pp. 285-320.

Gardbaum, S., "Separation of powers and the growth of judicial review in established democracies (or why has the model of legislative supremacy mostly been withdrawn from sale?)", en American journal of comparative law 3 (2014), pp. 613-639, en https://doi.org/10.5131/AJCL.2014.0020 
Gardbaum, S., "The New Commonwealth Model of Constitutionalism”, en The American Journal of Comparative Law 49 (4) (2001), pp. 707-760, en https:// doi.org/10.2307/841055

Ginsburg, T., "Confucian constitutionalism? The emergence of constitutional review in Korea and Taiwan", en Law E Social Inquiry 27 (4), 2002, pp. 763799, en https://doi.org/10.1111/j.1747-4469.2002.tb00981.x

Ginsburg, T., "Constitutional Courts in East Asia: Understanding variation", en J. Comp. L., 3 (2008), p. 80.

Ginsburg, T., "Economic analysis and the design of constitutional courts", en Theoretical Inquiries in Law 3 (1) (2002), en https://doi.org/10.2202/15653404.1042

Ginsburg, T., Caldeira, G. A., Kelemen, R. D. y Whittington, K. E., "The global spread of constitutional review", en Oxford Handbook of Law and Politics, Oxford, Oxford University Press, 2008.

Ginsburg, T. y Simpser, A. (eds.), Constitutions in Authoritarian Regimes, Cambridge, Cambridge University Press, 2013 en https://doi.org/10.1017/ CBO9781107252523

Ginsburg, T. y Versteeg, M., “Why do countries adopt Constitutional Review?”, en The Journal of Law, Economics, and Organization 30 (3) (2014), pp. 587-622, en https://doi.org/10.1093/jleo/ewt008

Goderis, B. y Versteeg, M., “Transnational Constitutionalism: A conceptual framework", en D. J. Galligan y M. Versteeg (eds.), Social and Political Foundations of Constitutions, Cambridge, Cambridge University Press, 2013, pp. 103-133, en https://doi.org/10.1017/CBO9781139507509.007

Golder, B., "Beyond redemption? Problematising the critique of human rights in contemporary international legal thought", en London Review of International Law 2 (1) (2014), pp. 77-114, en https://doi.org/10.1093/lril/lru001

Goodman, R. y Jinks, D., "How to influence states: Socialization and international human rights law", en Duke lj 54 (2004), p. 621.

Government of Canada, Department of Global Affairs, Trade, and Investment, Canada's Enhanced Corporate Social Responsibility Strategy (CSR) to Strengthen Canada's Extractive Sector Abroad.

Graber, M. A., “The nonmajoritarian difficulty: Legislative deference to the judiciary", en Studies in American Political Development 7 (1) (1993), pp. 3573, en https://doi.org/10.1017/S0898588X00000687 
Greenberg, U., The Weimar Century: German Émigrés and the Ideological Foundations of the Cold War, Princeton, Princeton University Press, 2015, en https:// doi.org/10.1515/9781400852390

Hallstein, W., Die europäische Gemeinschaft, 5 ed., Viene, Econ, 1979.

Halmai, G., "The reform of constitutional law in Hungary after the transition", en Legal Studies 18 (2) (1998), pp. 188-196.

Harten, G. V., Investment Treaty Arbitration and Public Law, Oxford, Oxford University Press, 2008.

Herzog, R. y Gerken, L., "Stop the European Court of Justice", EUobserver, en https://euobserver.com/opinion/26714.

Hirschl, R., "Negative rights vs. positive entitlements: A comparative study of judicial interpretations of rights in an emerging neo-liberal economic order", en Hum. Rts. Q., 22 (2000), p. 1060, en https://doi.org/10.1353/hrq.2000.0044

Hirschl, R., "The strategic foundations of constitutions", en D. J. Galligan y M. Versteeg (eds.), Social and Political Foundations of Constitutions, Cambridge, Cambridge University Press, 2013, pp. 157-181, en https://doi.org/10.1017/ CBO9781139507509.009

Hirschl, R., Towards Juristocracy: The Origins and Consequences of the New Constitutionalism, Cambridge, Harvard University Press, 2004.

Hobson, C., "The origins of Judicial Review: A historian's explanation", en Washington and Lee Law Review 56 (3) (1999), p. 811.

Hoffmann, L. H., "Speech by Lord Hoffmann: The universality of human rights", 2009, en https://www.judiciary.uk/announcements/speech-bylord-hoffmann-the-universality-of-human-rights/.

Holmes, S. y Sunstein, C. R., "The politics of constitutional revision in Eastern Europe", en S. Levinson (ed.), Responding to Imperfection. The Theory and Practice of Constitutional Amendment, Princeton, Princeton University Press, 1995, pp. 275-306, en https://doi.org/10.1515/9781400821631.275

Hong, M., "Human dignity, identity review of the European arrest warrant and the Court of Justice as a listener in the dialogue of courts: Solange-III and Aranyosi: BVerfG 15 December 2015, 2 BvR 2735/14, Solange III, and ECJ (Grand Chamber) 5 April 2016, joined cases C-404/15 and C-659/15 PPU, Aranyosi and Căldăraru", en European Constitutional Law Review 12 (3) (2016), pp. 549-563, en https://doi.org/10.1017/S1574019616000365

Hovell, D., "Kadi: King-slayer or king-maker? The shifting allocation of decisionmaking power between the UN Security Council and Courts", en The Modern Law Review 79 (1) (2016), pp. 147-166, en https://doi.org/10.1111/1468-2230.12170 
Huneeus, A., "Constitutional lawyers and the Inter-American Court's varies authority", en Law E Contemporary Problems 79 (2016), 179-207.

Huntington, S. P., The Third Wave: Democratization in the Late 20th Century, Norman, University of Oklahoma Press, 1993.

Husa, J., "Guarding the constitutionality of laws in the nordic countries: A comparative perspective", The American Journal of Comparative Law 48 (3) (2000), pp. 345-381, en https://doi.org/10.2307/840859

Issacharoff, S., "Constitutional courts and democratic hedging", en Geo. LJ 99 (2010), p. 961.

Jackson, V. C., "Comparative constitutional federalism and transnational judicial discourse", en International Journal of Constitutional Law 2 (1) (2004), pp. 91-138, https://doi.org/10.1093/icon/2.1.91

Jackson, V. C., “Comparative constitutional law: Methodologies”, en M. Rosenfeld y A. Sajó (eds.), The Oxford Handbook of Comparative Constitutional Law, Oxford, Oxford University Press, 2012, en https://doi.org/10.1093/ oxfordhb/9780199578610.013.0004

Jaklic, K., Constitutional Pluralism in the EU, Oxford, Oxford University Press, 2014, en https://doi.org/10.1093/acprof:oso/9780198703228.001.0001

Kawagishi, N., "The birth of judicial review in Japan", International Journal of Constitutional Law 5 (2) (2007), pp. 308-331, en https://doi.org/10.1093/ icon/mom011

Keller, H. y Sweet, A. S. (eds.), A Europe of rights: the impact of the ECHR on national legal systems, Oxford, Oxford University Press, 2008, en https://doi. org/10.1093/acprof:oso/9780199535262.001.0001

Kelsen, H., "La garantie juridictionnelle de la Constitution”, en Revue de Droit Publique et Science Politique en France et á l'Étranger 45 (1928), pp. 197-257.

Kennedy, D., “The move to institutions”, Cardozo Law Rev. 8 (1986), p. 841.

Kennedy, D. y Mayhew, D., The Dark Sides of Virtue: Reassessing International Humanitarianism, Princeton, Princeton University Press, 2004, en https:// doi.org/10.1515/9781400840731

Kingsbury, B., "Sovereignty and inequality", European Journal of International Law 9 (4) (1998), pp. 599-625, en https://doi.org/10.1093/ejil/9.4.599

Kingsbury, B. y Schill, S. W., "Investor-state arbitration as governance: fair and equitable treatment, proportionality and the emerging global administrative law", en A. J. Berg (ed.), 50 Years of the New York Convention: ICCA 
International Arbitration Conference, Alphen aan den Rijn, Kluwer Law International, 2009, en https://doi.org/10.2139/ssrn.1466980

Klarman, M. J., "Rethinking the civil rights and civil liberties revolutions", en Virginia Law Review 82 (1) (1996), pp. 1-67, en https://doi.org/10.2307/1073565

Kommers, D. P., The Constitutional Jurisprudence of the Federal Republic of Germany, Durham, Duke University Press, 1997.

Kommers, D. P. y Miller, R. A., The Constitutional Jurisprudence of the Federal Republic of Germany: Third edition, Revised and Expanded, Durham, Duke University Press, 2012, en https://doi.org/10.2307/j.ctv125jqj0

Kramer, L. D., The People Themselves: Popular Constitutionalism and Judicial Review, Oxford, Oxford University Press, 2005.

Krenzler, H. G. y Landwehr, O., "'A new legal order of international law': On the relationship between Public International Law and European Union Law after Kadi", en From Bilateralism to Community Interest, Oxford, Oxford University Press, 2011, en https://doi.org/10.1093/acprof: oso/9780199588817.003.0063

Kumm, M., "Institutionalising socratic contestation: the rationalist human rights paradigm, legitimate authority and the point of judicial review", en Eur. J. Legal Stud. 1 (2007), p. 153.

Law, D. S., "Globalization and the future of constitutional rights", en Nw. UL Rev. 102 (2008), p. 1277.

Law, D. S. y Chang, W. C., "The limits of global judicial dialogue", en Washington Law Review 86 (2011), p. 523.

Law, D. S. y Versteeg, M., "The evolution and ideology of global constitutionalism", en California Law Review 99 (2011), p. 1163, en https://doi.org/10.2139/ ssrn. 1633108

Malová, D., "The role and experience of the Slovakian Constitutional Court", en Constitutional Justice, East and West: Democratic Legitimacy and Constitutional Courts in Post-Communist Europe in a Comparative Perspective 62 (2002), p. 349.

Maruste, R. y Schneider, H., “Constitutional Review in Estonia-Its principal scheme, practice and evaluation", en R. Müllerson, M. Fitzmaurice y M. Andenas (eds.), Constitutional Reform and International Law in Central and Eastern Europe, Leiden, Brill, 1998.

Mautner, M., Law and the Culture of Israel, Oxford, Oxford University Press, 2011, en https://doi.org/10.1093/acprof:oso/9780199600564.001.0001 
Maveety, N. y Pettai, V., "Government Lawyers and Non-judicial Constitutional Review in Estonia", en Europe-Asia Studies 57 (1) (2005), pp. 93-115, en https://doi.org/10.1080/0966813052000314129

Mazower, M., Governing the World: The History of an Idea, 1815 to the Present, New York, Penguin Books, 2013.

McCrudden, C., "Common law of human rights?: Transnational judicial conversations on constitutional rights", en Oxford Journal of Legal Studies 20 (4) (2000), pp. 499-532, en https://doi.org/10.1093/ojls/20.4.499

Moravcsik, A., "The origins of human rights regimes: Democratic delegation in postwar Europe", en International Organization 54 (2) (2000), pp. 217-252, en https://doi.org/10.1162/002081800551163

Moyn, S., "A powerless companion: Human rights in the age of neoliberalism", en Law and Contemporary Problems 77 (2014), p. 147.

Moyn, S., Christian Human Rights, Philadelphia, University of Pennsylvania Press, 2015.

Moyn, S., The Last Utopia: Human Rights in History, Cambridge, Belknap Press: An Imprint of Harvard University Press, 2012, en https://doi.org/10.2307/j. ctvjk2vkf

Mutua, M., Human rights: A political and cultural critique, Philadelphia, University of Pennsylvania Press, 2002, en https://doi.org/10.9783/9780812204155

Navia, P. y Ríos-Figueroa, J., "The constitutional adjudication mosaic of Latin America", en Comparative Political Studies 38(2), 2005, en https://doi. org/10.1177/0010414004271082.

Olsen, F., "Statutory rape: A feminist critique of rights analysis", en Texas Law Review 63 (1984), p. 387.

Palombella, G., "Interlegality and justice", 2017, en https://doi.org/10.2139/ ssrn.3066001

Pavoni, R., "Freedom to choose the legal means for implementing UN Security Council Resolutions and the ECJ Kadi Judgment: A misplaced argument

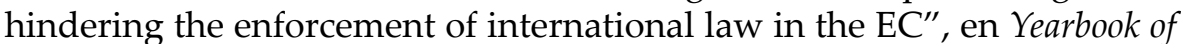
European Law 28 (1) (2009), p. 626, en https://doi.org/10.1093/yel/28.1.626

Pildes, R., "Ethnic identity and democratic institutions: A dynamic perspective", en S. Choudhry (ed.), Constitutional Design for Divided Societies: Integration or Accommodation?, Oxford, Oxford University Press, 2008, pp. 173-202.

Prakash, S. y Yoo, J., "The origins of Judicial Review", en University of Chicago Law Review 70 (3) (2003), en https://doi.org/10.2307/1600662 
Rakove, J. N., "The origins of Judicial Review: A plea for new contexts", en Stanford Law Review 49 (5) (1997), pp. 1031-1064, en https://doi. org/10.2307/1229247

Ramsay, P., "Faking democracy with prisoners' voting rights", en LSE Legal Studies Working Paper (2013), en https://doi.org/10.2139/ssrn.2214813

Roberts, A., "Comparative international law? The role of national courts in creating and enforcing international law", International \& Comparative Law Quarterly 60 (1) (2011), pp. 57-92, en https://doi.org/10.1017/S0020589310000679

Rosenfeld, M., The identity of the constitutional subject: selfhood, citizenship, culture, and community, London, Routledge, 2009, en https://doi. org/10.4324/9780203868980

Rosenfeld, M., Sadurski, W. y Toniatti, R., "Central and Eastern European constitutionalism a quarter century after the fall of the Berlin Wall: Introduction to the Symposium", en International Journal of Constitutional Law 13 (2015), en https://doi.org/10.1093/icon/mov014

Sabaliunas, L., "Comparative perspectives on judicial review in Lithuania", en Europe-Asia Studies 48 (5) (1996), pp. 783-795, en https://doi. org/10.1080/09668139608412381

Sadurski, W., Rights Before Courts: A Study of Constitutional Courts in Postcommunist States of Central and Eastern Europe, 2. ed, Dordrecht, Springer, 2014, https://doi.org/10.1007/978-94-017-8935-6

Sajó, A., "Reading the Invisible Constitution: Judicial Review in Hungary", Oxford Journal of Legal Studies 15 (2) (1995), pp. 253-267, https://doi. org/10.1093/ojls/15.2.253

Sauvant, K. P., "The rise of international investment, investment agreements and investment disputes", en K. P. Sauvant y M. Chiswick-Patterson (eds.), Appeals Mechanism in International Investment Disputes, Oxford, Oxford University Press, 2008.

Scharpf, F. W., "Monetary union, fiscal crisis and the disabling of democratic accountability", en Politics in the Age of Austerity (2013), pp. 108-142.

Schneiderman, D., Constitutionalizing Economic Globalization: Investment Rules and Democracy's Promise, Cambridge, Cambridge University Press, 2008.

Schwartz, H., The Struggle for Constitutional Justice in Post-Communist Europe, Chicago, University of Chicago Press, 2000.

328 Shapiro, M., Courts: a Comparative and Political Analysis, Chicago, University of Chicago Press, 2013. 
Shapiro, M., "The Success of Judicial Review in Constitutional Dialogues in Comparative Perspective" en S. J. Kenney, W. M. Reisinger y J. C. Reitz (eds.). Constitutional Dialogues in Comparative Perspective, London, Palgrave Macmillan UK, 1999, pp. 193-219, en https://doi.org/10.1057/9780333982518_9

Shapiro, M. y Sweet, A. S., On Law, Politics, and Judicialization, Oxford, Oxford University Press, 2002, https://doi.org/10.1093/0199256489.001.0001

Simmons, B. A., Mobilizing for Human Rights: International Law in Domestic Politics, Cambridge, Cambridge University Press, 2009, en https://doi. org/10.1017/CBO9780511811340

Simmons, B. A. y Elkins, Z., “The globalization of liberalization: Policy diffusion in the international political economy", en American Political Science Review 98 (1) (2004), pp. 171-189, en https://doi.org/10.1017/S0003055404001078

Simpson, A. W. B., Human rights and the end of empire: Britain and the genesis of the European Convention, Oxford, Oxford University Press, 2004.

Slaughter, A. M., Sweet, A. S. y Weiler, J., The European Court and National Courts: Doctrine \& Jurisprudence: Legal Change in Its Social Context, London, Bloomsbury Publishing, 1998.

Slaughter, A.-M., "A typology of transjudicial communication", en U. Rich. L. Rev. 29 (1994), p. 99.

Sripati, V., "Toward fifty years of constitutionalism and fundamental rights in India: Looking back to see ahead (1950-2000)", en American University International Law Review 14 (2) (1998).

Sterett, S., "Judicial review in Britain", en Comparative Political Studies 26 (4) (1994), pp. 421-442, en https://doi.org/10.1177/0010414094026004002

Stolleis, M., "Judicial review, administrative review, and constitutional review in the Weimar Republic", en Ratio Juris 16 (2) (2003), pp. 266-280, en https:// doi.org/10.1111/1467-9337.00236

Stone, A., The Birth of Judicial Politics in France: The Constitutional Council in Comparative Perspective, New York, Oxford University Press, 1992.

Stone Sweet, A., Governing with judges: constitutional politics in Europe, Oxford, Oxford University Press, 2000, en https://doi.org/10.1093/0198297718.003.0007

Stone Sweet, A. y Brunell, T. L., "Trustee courts and the judicialization of international regimes: The politics of majoritarian activism in the European convention on human rights, the European Union and the world trade organization", en Journal of Law and Courts 1 (1) (2013), pp. 61-88, en https:// doi.org/10.1086/668499 
Sweet, A. S., "A cosmopolitan legal order: Constitutional pluralism and rights adjudication in Europe", Global Constitutionalism 1 (1) (2012), pp. 53-90, en https://doi.org/10.1017/S2045381711000062

Thornhill, C., A Sociology of Constitutions: Constitutions and State Legitimacy in Historical-Sociological Perspective, Cambridge,Cambridge University Press, 2011, en https://doi.org/10.1017/CBO9780511895067

Travis, A., "Up to 100 prisoners on short sentences to be given right to vote", The Guardian, en http://www.theguardian.com/society/2017/nov/02/up-to100-prisoners-on-short-sentences-to-be-given-right-to-vote

Treanor, W. M., "Judicial Review before Marbury", en Stanford Law Review 58 (2) (2010), pp. 455-562.

Trochev, A., "Less democracy, more courts: a puzzle of judicial review in Russia", en Law E Society Review 38 (3) (2004), pp. 513-548, en https://doi. org/10.1111/j.0023-9216.2004.00056.x

Tushnet, M., Taking the Constitution away from the Courts, Princeton, Princeton University Press, 2000, en https://doi.org/10.1515/9781400822973

Tzanakopoulos, A., "Judicial dialogue in multi-level governance: the impact of the Solange argument", en The practice of international and national courts and the (de-) fragmentation of international law, Oxford, Hart Publishing, 2009, pp. 185-215.

Van der Schyff, G. y Adams, M., "Constitutional Review by the judiciary in the Netherlands: A bridge too far?", en German Law Journal 112 (2010), pp. 275-290, https://doi.org/10.1017/S2071832200018526

Waldron, J., "The core case against Judicial Review”, en The Yale Law Review 115 (6) (2006), pp. 1346-1406, en https://doi.org/10.2307/20455656

Waltz, K. N., Theory of International Politics, Long Grove,Waveland Press, 2010.

Watson, A., Legal Transplants: An Approach to Comparative Law, 2 ed., Athens, University of Georgia Press, 1993.

Wegen, G. y Kuner, C., “Germany: Federal constitutional court decision concerning the Maastricht Treaty", en International Legal Materials 33 (2) (1994), pp. 388-444, en https://doi.org/10.1017/S0020782900026401

Weiler, J. H. H., “Editorial”, en The European Journal of International Law 19 (5) 2008, pp. 895-899, https://doi.org/10.1093/ejil/chn075

330 Weiler, J. H. H., "The geology of international law-governance, democracy and legitimacy", en ZaöRV 64 (2004). 
Weiler, J. H. H., "The transformation of Europe”, en Yale Law Journal (1991), 2403-2483, en https://doi.org/10.2307/796898

Weingast, B. R., "Constitutions as governance structures: The political foundations of secure markets", Journal of Institutional and Theoretical Economics (JITE)/Zeitschrift für die gesamte Staatswissenschaft (1993), pp. 286-311.

Weinrib, L., "Constitutional conceptions and constitutional comparativism", en V. C. Jackson y M. Tushnet (eds.), Defining the Field of Comparative Constitutional Law, Westport, Praeger, 2002.

Weinrib, L., "The postwar paradigm and American exceptionalism”, en Legal Studies Research Paper 899131 (2006), pp. 83-113.

West, R. L., "Tragic rights: The rights critique in the age of Obama”, en William $\mathcal{E}$ Mary Review 53 (2011), p. 713.

Whittington, K. E., “"Interpose your friendly hand”: Political supports for the exercise of judicial review by the United States Supreme Court", en American political science review 99 (4) (2005), pp. 583-596, en https://doi. org/10.1017/S0003055405051890

Wiener, A. y Liste, P., "Lost without translation? Cross-referencing and a new global community of courts", en Indiana Journal of Global Legal Studies 21 (1) (2014), pp. 263-296, https://doi.org/10.2979/indjglolegstu.21.1.263

Williams, P. J., Alchemy of Race and Rights: Diary of a Law Professor, Cambridge, Harvard University Press, 1992.

Wolczuk, K., "The Constitutional Court of Ukraine: The politics of survival”, en Constitutional Justice, East and West: Democratic Legitimacy and Constitutional Courts in Post-Communist Europe in a Comparative Perspective 62 (2002), p. 327.

Wood, G., "The origins of Judicial Review revisited, or how the Marshall Court made more out of less", Washington and Lee Law Review 56 (3) (1999), p. 787.

Yoshino, K. y Kavey, M., “Immodest claims and modest contributions: Sexual orientation in Comparative Constitutional Law", en M. Rosenfeld y A. Sajó (eds.), The Oxford Handbook of Comparative Constitutional Law, Oxford, Oxford University Press, 2012, en https://doi.org/10.1093/oxfordhb/9780199578610.013.0054

Zendeli, E., "The challenges of the implementation of paragraph 1 of article 6 of the European Convention on Human Rights and Fundamental Freedoms in the judicial system of the Republic of Macedonia", en Journal of Politics and Law 6 (2) (2013), pp. 193, en https://doi.org/10.5539/jpl.v6n2p193

Zurn, M., Nollkaemper, A. y Peerenboom, R., Rule of law dynamics: in an era of international and transnational governance, Cambridge, Cambridge University Press, 2012, en https://doi.org/10.1017/CBO9781139175937 


\section{Normatividad}

Constitución de Cuba, 1992.

Constitución de la República de Sudáfrica, 1996.

Constitución de la República Federativa de Brasil, 1988.

Constitución de la República Italiana, 1948.

Constitución Política de los Estados Mexicanos, 2005.

United Nations, Res. 1267.

United Nations, Res. 1333.

United Nations, S.C. Res. 1390, U.N. S.C.O.R., 57th Sess., 4452d Mtg.

\section{Jurisprudencia}

Bundesverfassungsgericht (Tribunal Constitucional Federal de Alemania), BvE 2/08 - Lisbon -t, 2009.

Bundesverfassungsgericht (Tribunal Constitucional Federal de Alemania), BVerfGE 89, 155 - Maastricht - I.L.M. 388, 395, 1993.

Bundesverfassungsgericht (Tribunal Constitucional Federal de Alemania), BVerfGE 129 (E.F.S.F.) , 2011.

Bundesverfassungsgericht (Tribunal Constitucional Federal de Alemania), BvR 256/08 (Data Retention), 2010.

Bundesverfassungsgericht (Tribunal Constitucional Federal de Alemania), BvR 2735/14, 2015.

Corte costituzionale della Repubblica Italiana, Sentenza 238 del 22 ottobre 2014.

Corte Interamericana de Derechos Humanos, Fontevecchia and D'Amico v. Argentina. Fondo Reparaciones y Costas, Serie C No. 238, 2011.

European Court of Justice, European Commission v. Kadi, EU:C:2013:518, C-584/10 P, C-593/10 P, and C-595/10 P, 2013.

332 European Court of Human Rights, Hirst v. United Kingdom (No. 2), 2005-IX, 42 E.H.R.R. 41, 2005. 
European Court of Justice, Internationale Handelsgesellschaft mbH v Einfuhr- und Vorratsstelle für Getreide und Futtermittel. Reference for a preliminary ruling: Verwaltungsgericht Frankfurt am Main - Germany, ECLI:EU:C:1970:114, 1970.

European Court of Justice, Parti écologiste "Les Verts" v European Parliament. Judgment of the Court of 23 April 1986, Case 294/83.

General Court of the European Union, Kadi v. Council of the European Union, E.C.R. I-6351, EU:C:2008:461, C-402/05 P, C-415/05 P, 2008.

General Court of the European Union, Kadi v. European Commission, E.C.R. II-5177, EU:T:2010:418 - 2010.

General Court of the European Union, Kadi v. Council of the European Union, E.C.R. II-3659, Court of First Instance, T-315/01, 2005.

Heonbeop Jaepanso (Corte Constitucional de Corea del Sur), 16-2(A) KCCR 141 (Caso de la Objeción de Conciencia para Servicio Militar) - 헌 법재판소, 2002Hun-Ka1.

Heonbeop Jaepanso (Corte Constitucional de Corea del Sur), 20-2(A) KCCR 696 (Caso del Adulterio) -헌법재판소 , 2007 Hun-Ka17·21; 2008 Hun-Ka7·26; 2008 Hun-Ba21.47.

Heonbeop Jaepanso (Corte Constitucional de Corea del Sur), 22-1(A) KCCR 36 (Caso de la Pena de Muerte) - 헌법재판소, 2008Hun-Ka23. 22-1(A).

High Court of Justice (Israel), Mara'abe v. Prime Minister of Israel, H.C.J. 7957/04, 2005.

Indra Sawhney Etc. Etc vs Union Of India And Others, Etc - AIR 1993 SC 477, 1992 Supp 2 SCR 454, 1992.

Supreme Court of the United Kingdom, R (on the application of Chester) (Appellant) v Secretary of State for Justice (Respondent) - [2013] U.K.S.C. 63, 2013.

Supreme Court of the United Kingdom, R v Horncastle \& Others - [2009] UKSC 14, 2009.

Tribunal Constitucional de Chile, Procedimiento: Requerimiento de inaplicabilidad por inconstitucionalidad. Causa: 1881-10, 2011.

Tribunal Constitucional de España, Declaración 1/2004, BOE núm. 3, de 04 de enero de 2005.

Tribunal Constitucional de España, Sentencia 26/2014, BOE núm. 60, de 11 de marzo de 2014. 
Trybunał Konstytucyjny (Tribunal Constitucional de Polonia), Wyrok, Trybunału Konstytucyjnego, z dnia 11 maja 2005 r. (Constitutionality of the Accession Treaty)- K 18/04, 2010.

Trybunał Konstytucyjny (Tribunal Constitucional de Polonia), Wyrok, Trybunału Konstytucyjnego, z dnia 16 listopada 2011 r. (Constitutionality of the Council Regulation (EC) No. 44/2001 of December 22, 2000, on jurisdiction and the recognition and enforcement of judgments in civil and commercial matters) - SK 45/09, 2000.

Trybunał Konstytucyjny (Tribunal Constitucional de Polonia), Wyrok. Trybunału Konstytucyjnego, z dnia 24 listopada 2010 r. (Constitutionality of the Treaty of Lisbon)- K 32/09, 2010.

Ústavní soud České republiky (Corte Constitucional de la República Checa), Lisabonská smlouva pozměňující Smlouvu o Evropské unii a Smlouvu o založení Evropského společenství II. Pl.ÚS 29/09 ze dne 3. 11. 2009 (Constitutionality of the Treaty of Lisbon II), N 233/55 SbNU 197, 2009.

Ústavní soud České republiky (Corte Constitucional de la República Checa), Lisabonská smlouva pozměňující Smlouvu o Evropské unii a Smlouvu o založení Evropského společenství. Pl.ÚS 19/08 ze dne 26. 11. 2008 (Constitutionality of the Treaty of Lisbon I), 446/2008 Sb. - N 201/51 SbNU 445, 2008.

Xianggang Zhongshenfayuan (Corte de Apelaciones Finales de Hong Kong), Director of Immigration v. Chong Fung Yuen - 香港終審法院, H.K.C.F.A. 48; [2001] 2 H.K.L.R.D. 533; (2001) 4 H.K.C.F.A.R. 211; FACV 26/2000

Xianggang Zhongshenfayuan (Corte de Apelaciones Finales de Hong Kong), $\mathrm{Ng}$ Ka Ling and Another v. Director of Immigration - 香港終審法院 - [1999] H.K.C.F.A. 72; [1999] 1 H.K.L.R.D. 315; (1999) 2 H.K.C.F.A.R. 4; [1999] 1 H.K.C. 291; FACV 14/1998, 1999.

Xianggang Zhongshenfayuan (Corte de Apelaciones Finales de Hong Kong), W v Registrar of Marriages - 香港終審法院 [2013] HKCFA 39; FACV 4/2012, 2013.

Конституционный Суд Российской Федерации (Corte Constitucional de la Federación Rusa), Постановление Конституционного Суда РФ от 14.07.2015 N 21-П (Sentencia de la Corte Constitucional de la Federación Rusa del 14 de julio de 2015-21-П). 